




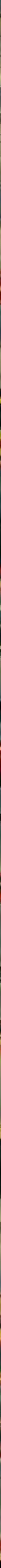



Drvision of 1 alimelts

Berfincelth'th Tा 





\section{MONOGRAPH OF THE GENUS}

\section{Devision of Mollecks Section'til Jinery \\ TELLI N A.}

BY

SYLVANUS HANLEY, B. A. F. L.S. \&c.

EXTRACTED FROM THE FIRST VOLUME OF THE "THESAURUS CONCHYLIORUM."

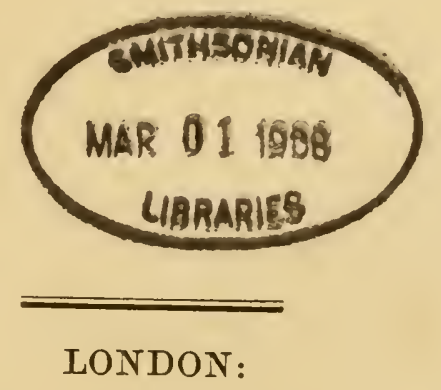

J A N U A R Y 3, 1846. 


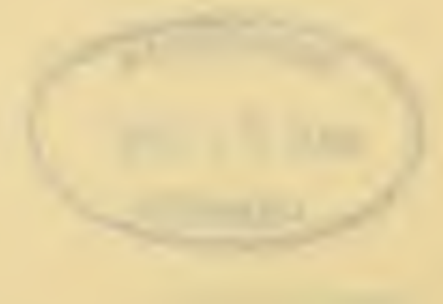





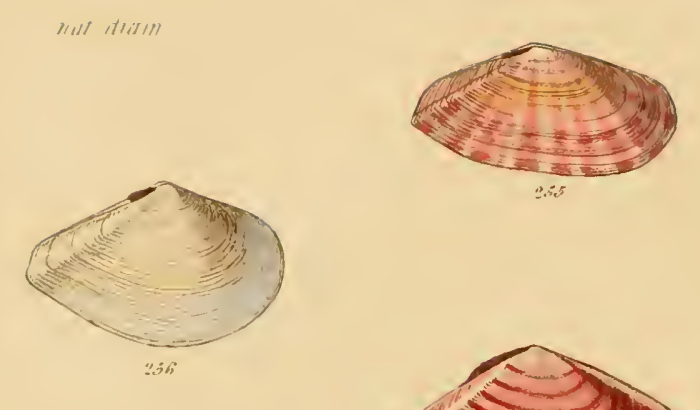

LXVI
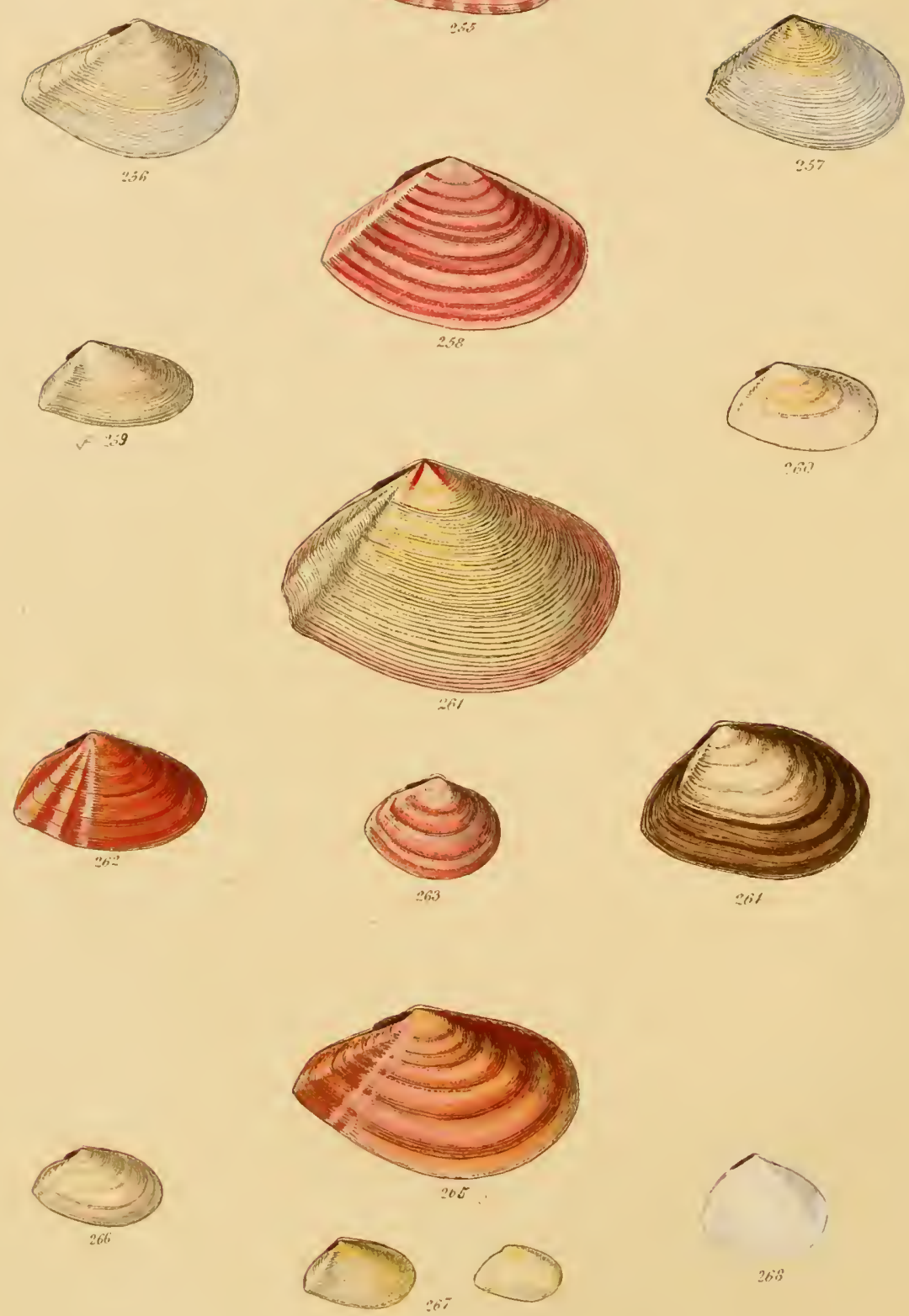


\section{PART VI.}

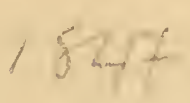

OF THF

\section{THESAURUS CONCHYLIORUM;}

EDITED AND ILIUSTRATED BY

\section{G. B. SOWERBY, JUN. F.L.S.}

Each Part contains one or more Monograpits of Genera of Recent Shells, including a description and figure of each species and variety known up to the time of publication, with its locality and essential synonymes. The work, when completed, will form a Conchological LiBrary, sufficiently comprehensive to render all otlier works on the subject unnecessary to collectors.

The Proprietor is happy to state that the first six Parts now before the public, have given universal satisfaction; and he will endeavour to deserve a continuance of the approbation which has been freely expressed.

The price of each Part is calculated at the rate of about one shilling for twelve figures.

Parts 1, 2, 3, 4, 5, and 6, contain Monograplss of the Genera IIFlicina, Pupina, Rostellaria, Aporrhais, Struthiolaria, Strombus, Pecten, Pteroceras, Hinitites, Lima, Cyclostoma, Scataaria, Columbella, Terebra, Voluta, Tellina (including Tellinides), and Lingula, illustrated by nearly 1,800 figures.

Monographs of the following Genera are now in preparation.

Terebratula and the other genera of Brachiopoda

by G. B. Sowerby F.L.S.

Spoxdylus and Plicatula by G. B. Sowerby, Jum. F.I.S.

Cruba and Mezo, by G. B. Sowerby, F.L.S.

Crclus by G. B. Sowerby, F.L.S.

Marginelta, by G. B. Sowerby, Jun. F.L.S.

In returning thanks for support already received, the Proprietor begs to mention that such support would have been much more extensive but for a disinclination on the part of some to take the numbers of a periodical publication during its progress. It should, however, be remembered, that each Part of the 'Thesaurus Conchyliorum' is

\section{COMPLETE IN ITSELF,}

independently of the general design which it assists in carrying out. Each Monograph, containing all the information that can be collected respecting the Species of a Genus, might, with propriety, be published separately, and under a distinct title.

The Proprietor may further observe; that it will be his aim to arrange for the completion of Families as speedily as circumstances will permit. Thus, one Family is completed by the already published Monographs of the genera Helicina, Pupina, and Cyclostoma, which include all operculated land shells. Another Family is completed by the genera Rostellaria, Aporrhais, Struthiolaria, Strombus, and Pteroceras. To the already given Monographis 
of Peeten and Lima, will shortly be added those of Spondylus and Plicatula; the Family of Volutidæ will be eompleted in an carly Part, by the Genera Cymba and Melo. Part seven will contain, with other genera, all the remain ing Brachiopoda.

GEOLOGISTS, who have long needed a Work like the present to enable them to compare their fossil specimens with the recent species of Shells, will find uncoloured copies well adapted to that purpose.

The following Learned Societies and individuals are known to have already placed the Thesaurus Conchyliorum in their Libraries:-

\section{HIS MAJESTY THE KING OF DENMARK. (Private library.) \\ IIS GRACE THE DUKE OF NORTHUMBERLAND,}

\section{THE MOST MOBLE THE MARQUIS OF NORTHAMPTON.}

The Linnean Society of London.

The United Service Institution, London.

The Fidinburgh College Library.

Imperial Academy of Sciences, Moseow.

Muscum of Bremen.

Imperial Miseum of Zoology, Vienna.

Royal Asiatic Society, Calcutta.

Royal Muscum of the Jardin des Plantes, Paris.

Royal Museum of Berlin.

Philosophical Institution of York.

Royal Museum of Stockholm.

Trinity College, Dublin (coloured copy).

Sir David Barclay, Bart.

The Hon. Col. Macadam Catheart.

II. le Baron Delessert, Paris.

Count Keysserling St. Petersburgl.

Lady Buxton.

Miss Brookes.

Miss Saul.

Miss Thompson, Stamford.

Dr. Sehmidt, Bremen.

Dr. J. C. Jay, New York.

Dr. Jonas Hamburg.

The Rev. Dr. J. Pye Smith, F.R.S. \&e.

Rev. L. Vernon Hareourt.

Rev. Edward Budge.

Rev. J. F. Stainforth.

Rev. W. Croteh.

Rev. S. C. E. Neville Rolfe.

Rev. Thomas Image.

Rev. E. Rust.

W. W. Benson, Esq. Roekville, Landomr (Civil Service).

IIugh Cuning, Esq. F.L.S.

E.G.I. Gruner, Esq. Bremen

Isaac Lea, Esq. Philadelphia.

Thomas Lombe Taylor, Esq.

J. D. C. Sowerby, Esq. F.L.S.

R. Shuttleworth, Esq. Berne, Switzerland.
J. Dennison, Esq. Liverpool.

Beujamiu Butler, Esq. Manilla.

John Bates, Esq. R.N. See. Royal Yarht Sor.

Cowes, Isle of Wight.

Thos. Norris, Esq.

Lyttleton T. Powis, Esq. London.

W. Metcalfe, Esq. London.

E. Logan, Esq. New York.

G. Hubbard, Esq.

Wm. Durrant, Esq.

Wm. K. Loftns, Esq. Cambridge.

J. Meynell, Esq. York.

Lient. Hankey R.N.

J. G. Gaskoin, Esq.

C. I. F. Bunbury, Esq. F.G.S.\&e.

Sylvanus Hanley, Esq. F.L.S.

J. G. Gabriel, Esq.

Wm. Bean, Esq.

Edward Broughton, Esq. Edinburglı.

J. Miers, Esq. F.R.S. \&c.

W. J. Broderip, Esq. F.R.S. \&c.

R. B. Hinds, Esq. R.N.

M. Jargilliert, Ronen.

Thos. Bell, Esq. F.R.S. \&e.

M. Petit de la Saussaye, Paris.

M. D’Aleide D’Orbigny, Paris.

Samucl Stutehbury, Esq. Bristol.

Dr. Charles Theodore Menke, Pyrmont, Waldeck, Germany.

T. Bridges, Esq. F.R.S. Valparaiso,

James Tennant, Esq. F.G.S.

M. Giovanni Michelotti, Turin.

W. Borrer, Esq. F.R.S. \&e.

M. Krantz, Berlin.

M. Deshayes, Paris

W. Parker Hammond, Esq.

T. Berriugton, Esq.

R. Camplell, Esq.

M. Janelle, Paris.

The Proprietor will feel obliged if those Purchasers of the Work whose names are omitted from the above List, would enable him to render it more complete by kindly forwarding their names to the Publisher for insertion; and any who may wish to purchase, or to inspect with a view to purehase Cojies, may have them forwarded to any part of Great Britain, Fiee or ExPENsE,

SOWERBY, BOOKSELLER AND DEALER IN MINERALS AND SHELLS, 50, GREAT RUSSELL STREET, BLOOMSBURY. 


\section{A MONOGRAPH OF THE GENUS}

\section{TELLINA.}

By SYLVANUS HANLEY, B.A., F.L.S., Eтc.

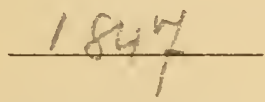

Char. Gen. Testa bivalvis, cujus latus posticum aut plicaturâ irregulari radiante tumescit, aut cardo ejns dentem dentesve duos laterales ostendit; dentes primarii duo, vel in utrâque, vel in alterâ valvulâ; margo ventralis nunquam crenatus; pallii cicatrix maximè sinuata; nymphæ haud prominentes. Ligamentum externum.

There are few genera whose definition is more difficult than that of Tellina. The typical species with a strong fold or umbonal ridge and two distinct lateral teeth, cannot indeed be confounded with the shells of any other genus; but the whole of the aberrant division, in which the fold is oftentimes nearly obsolete and the linge always devoid of lateral teeth, require the strictest examination, so closely do they approximate to Sanguinolaria and Psammobia. Lamarck himself has included several species of this division in Psammobia and Psammotxa (the latter genus abolished by the unanimous agreement of all conchologists); but the authority of Deshayes gives weight to my own opinion, of the necessity of their annexation to Tellina. The externally projecting nymphal callosities which support the prominent ligament, characters which are universal throughout Psammobia, are never present in Tellens of this division. I may remark moreover, as a further assistance to the discrimination of those closely allied genera, that the inclination of the line which unites the posterior muscular impression to the parallel scar is ascending in those aberrant species which most nearly approach Psammobia, whilst it is descending in that genus. I speak more particularly of Psammobia, as there exists in some of its species a fold almost equally profound (but symmetrical) with that of the majority of the Tellinæ. This does not exist in Sanguinolaria, of which I regard Rosea and not Rugosa as the type.

Certain Donaces, devoid of crenulated margins, might probably 
be mistaken for Tellinæ, but these being always perfectly equivalve, strong, wedge-shaped, or triangular shells, with a remarkably short prominent ligament, and the anterior side the more compressed, present a combination of characters which are never united in any of those Tellens in which the characteristic fold is imperfectly developed. The decided sinuation of the palleal scar suffices to separate any species from Lucina, Corbis, or Astarte.

\section{DESCRIPTION.}

* Two lateral teeth in one of the valves.

- 1. Tellina rostrata (pl. lxi. f. 157.) Lin., Syst. 1118; Lin. Mus. Ulr. 481 ; T. Spengleri, Chem. vol. vi. f. 85, 89 ; Wood, Gen. Conch. t. 37.f. 2 ; Lam. no. 8 ; Hanl. Des. Cat. p. 62. t. 4. f. 35 ; Enc. Mèth. t. 287. f. 5.

T. testâ elongato-subtrigonâ, angustâ, subinæquivalvi, subæquilaterali, solidâ, convexiusculâ, subflexuosâ, extus intusque candidâ, prope nates roseo pallidè pictâ, concentricè sulcatâ; sulcis confertis, obliquis; margine ventrali subrecto aut convexiusculo; dorsali utrinque subrecto et subrequaliter declivi; areis dorsalibus sublevigatis, squamis tuberculosis, utrinque dentatis; latere antico subacuminato; postico subrostrato, biangulato; costâ umbonali angulatâ; ligamento subinfosso ; dentibus lateralibus magnis, remotis.

Elongated-subtriangular, narrow, rather flexuous, almost equilateral, rather inequivalve, solid, moderately convex, white both cxternally and intermally, with a slight tinge of rose-colour near the beaks, closely and obliquely grooved concentrically; ventral edgc but little convex; dorsal margins nearly straight, and almost equally sloping; dorsal areas nearly smooth, and environed by scaly tubercles; anterior side subacuminated ; posterior biangulated and subrostrated; umbonal ridge angulated; ligament sunken ; lateral teeth strong and distant.

Island of Ticao, \&c,

This is not the Rostrata of Gmelin, Lamarck, nor the majority of writers, but nevertheless, as was surmised by Schumacher from the expression "ano rimâque, subserratis," is the species indicated by Linnæus, as his specimen in the Linnæan Society's cabinet clearly evidences. 
2. Tellina Deshayesir (pl. lvii. f. 66.) Hanley, Zool. Proc. 1844

T. testâ T. Rostratæ simillimâ, sed albido-roseâ, et lamellis subremotis concentricè ornatâ; margine etiam ventrali convexiore.

Extremely like T. rostrata, but of an uniform pale pinkish hue, and the surface ornamented with concentric and rather distant lamellæ; the ventral margin more convex likewise, than in the preceding species.

Red Sea?

3. Tellind Cumingir (pl. Iviii. f. 72.) Hanley, Zool. Proc. 1844.

T. testâ elongato-oblongâ, subæquilaterali, solidâ, compressiusculâ, vix nitidâ, albidâ aut flavescente, maculis strigis lineisve brunneis aut fusco-purpurascentibus radiatâ; concentricè sulcat $\hat{n}$, sulcis anticè confertis et subimbricatis, posticè sublamellosis, remotiusculis ; margine ventrali couvexo, utrinque sursum acclinato; dorsali utrinque subdeclivi, anticè convexiusculo, posticè subrecto, subincurvato, subdentato; latere postico attenuato, rostrato, paullulum breviore, ad extremitatem biangulato; costâ umbonali valdè prominente; ligamento inconspicno; superficie internâ albidâ aut flavidâ; dentibus lateralibus validis, subæquidistantibus.

Elongated-oblong, narrow, subequilateral, solid, rather compressed, scarcely glossy, whitish, radiated with narrow brown or chocolate-brown streaks or spots; concentrically sulcated, sulci fine, becoming elevated posteriorly, strong and coarse on the very prominent umbonal rilge, attenuated in the hollow beyond, and projecting again so as almost to dentate the straight or slightly concave ligamental margin; slopes very gentle; front dorsal area barred with coloured streaks; anterior extremity rounded, but somewhat attenuated; hinder side narrowed, subrostrated, and somewhat biangulated at the extremity ; inside white or pale yellowish; lateral teeth strong, and nearly equidistant.

Guacomayo and America.

4. Tellina crucigera (pl.lviii. f.78, 79 ; and pl.lxii. f. 178.) Lam., no. 7 ; Hanl. Des. Cat. p. 61.

T. testâ oblongâ, convexâ, inæquilaterali, nitidiusculâ, albidâ. lincis maculisque fulvo-aurantiis aut roseo-purpureis plerumque radiatâ; (rarius immaculatâ, et radio brevi roseo ad umbones utrinque ornatâ), sulcis exilibus, distinctis, paululum obliquis, concentricè exaratâ; margine ventrali convexo, posticè sursum acclinato; dorsali anticè convexiusculo et vix paululum declivi, posticè 
vix convexiusculo satisque declivi; latere antico manifestè longiore; postico atteuuato, subrostrato ; extremitate auticâ rotundatâ ; posticâ angulatâ ; costâ umbonali conspicuâ ; ligamento haud prominente; superficie internâ albidâ aut flavidâ; dentibus lateralibus distinctis, æquidistantibus.

Oblong, solid, convex, but slightly glossy, inequilateral, whitish, with (in the typical variety) two deep crimson short rays (thus forming a St. Andrew's cross upon the umbones), but usually only adorned with more or less interrupted rays of tawny-orange or faint lineated markings of purplish crimson, rather obliquely distinctly but not coarsely concentrically grooved; anterior side much the longer, and rounded at its extremity, its dorsal slope slight but convex; posterior side attenuated, the slightly convex ventral edge rising on that side, so as to form a beak in its junction with the moderately sloping and scarcely convex ligamental one; umbonal ridge blunt but conspicuous ; inside white or yellowish, the lateral teeth distinct, and equidistant. The typical variety is extremely rare, I have only seen two specimens in the collection of William Walton, Esq., and the original one in the French Museum.

Catbalouga, Isle of Samar ; \&c.

5. Telimina Antonir (pl. lviii. f. 74, 75; and pl. lx. f. 131.) 1'litippi, Ab. und Bes. Concl. pt. v. t. 5. f. 3.

T. testâ oblongo-elongatâ, solidâ, convexâ, albidâ aut purpureâ, maculis lincisve nebulosis radiantibus fusco-purpureis rubro-roseis aut fulvo-aurantiis plerumque ornatâ, concentricè sulcatâ et obsoletè radiatim striatâ ; sulcis posticè sublamellosis ; margine ventrali anticè crenato, posticè retuso et sursum acclinato; dorsali anticè vix declivi, posticè subrecto subincurvato satisque declivi; latere postico manifestè breviore, rostrato; flexurâ costâque umbonali conspicuis; ligamento subdepresso; dentibus lateralibus validis, subæquidistantibus.

Elongated-oblong, solid, convex, somewhat glossy, variable in colouring being uniform whitish or purple (both within and without), but more commonly subradiated by purplish brown or rosyred markings on a whitish ground; surface with very distinct concentric sulci, which become strong elevated striæ as they approach the prominent umbonal ridge, on and beyoud which they become sublamellar; the interstices traversed by nearly obsolete radiating strix; ventral edge swelling out in front and sloping иржаrds behind, so as to render the narrow and biangulated posterior extremity rostrated; anterior side decidedly the longer, its extremity rounded, its slope very slight ; ligamental edge straightish 
but somewhat incurved, its slope moderate : flexure conspicuous; lateral teeth strong and nearly equidistant.

Guadaloupe. 1844 .

6. Tellina verrucosa (pl. Ixviii. f. 77.) Hanley, Zool. Proc.

T. testâ oblongo-elongatâ, solidâ, compressâ ; aut flavidâ rubropurpureo radiatâ, aut pallidè roseâ radiis subalbidis angustis zonisque saturatioribus ornatâ ; valvulâ alterâ undique (natibus excipiendis) verrucosâ; alterâ medio concentricè sulcatâ, lateribus solìm verrucosâ; verrucis ellipticis aut semilunatis, in seriebus vix interruptis, concentricè ordinatis ; margine ventrali anticè subarcuato, posticè sursum acclinato; dorsali anticè convexiusculo et vix subdeclivi, posticè subrecto, subdeclivi; latere antico longiore, rotundato ; extremitate posticâ attenuatâ, subrostatâ, obliquè subbiangulatâ ; ligamento haud prominente; flexurâ ventrali costâque umbonali conspicuis; dentibus lateralibus magnis, æquidistantibus.

Elongated-oblong, depressed, solid, yellowish with reddish crimson rays or pale pink with deeper concentric bands and paler narrow rays; surface roughened in one valve by concentrically arranged and frequently connected compressed wart-like tubercles, which on the disc of the other valve are replaced by concentric elevated sulci; anterior side the longer, rounded; ventral edge arcuated anteriorly and curving upwards to the angulated posterior extremity so as to render it subrostrated and attenuated; slopes gentle, ligament not prominent; lateral teeth large.

Corrigidor, Bay of Manilla.

7. Tellina rastellum (pl. lxiv. f. 231. and pl. lxv. f. 24.2) Hanley, Zool. Proc. (April) 1844; Hanl. Des. Cat. sup. t. xiv. f. 14. T. Philippii, Anton Ab. und Bes Conch. part v. t. 5.

T. testâ elongatâ, solidâ, convexiusculâ, æquilaterali, flavidâ, pallidè roseo radiatâ ; anticè sulcatâ, posticè squamosâ, squamis erectis, lamellosis, in iisdem seriebus cum sulcis concentricis, ordinatis ; margine ventrali vix convexiusculo; dorsali utrinque paululum declivi, anticè vix convexiusculo, posticè recto ant subincurvato; latere postico attenuato, subrostrato, ad extremitatem obliquè biangulato ; extremitate anticâ rotundatâ; ligamento costâque umbonali, conspicuis ; superficie internâ albidâ, umbones versus aurantio utrinque fucatâ; dentibus lateralibus validis, subæquidistantibus.

Elongated, solid, moderately convex, equilateral, yellowish with pale crimson rays, the concentric sulci posteriorly so intcrrupted as to form rows of thin tootli-like scales, and so arranged that the 
teeth of one line are just beneath the interstices in the other ; dorsal slopes gentle, the posterior one nearly straight, anterior extremity somewhat narrowed and rounded, posterior end much attenuated and subrostrated; ventral edge but little convex; umbonal ridge, ligament, and flexuosity, very prominent; inside white, disc tinged with orange, a short orange ray on either side near the beak; lateral teeth strong, and subequidistant.

Zanzibar.

A species sometimes confused with Pulcherrima, but much more elongated, the strix stronger, and the scales entirely absent from the posterior side. It is not impossibly the Aspera of Gmelin, but that shell is too briefly described for recognition.

8. Tellina pulcherrima (pl. lxi. f. 165.) Sowerly, Tank. Cat. App. p. 3. t. 1. f. 1 ; Hanl. Des. Cat. p. 67. sup. t. 11. f. 14; Knorr. vol. iv. t. 25. f. 1 .

T. testâ oblongâ, solidâ, convexiusculâ, subæquilaterali, flavo rubroque radiatâ, in medio concentricè et tenuiter sulcatâ; utrinque squamosâ, sqamis erectis, dentiformibus aut sublumatis; margine ventrali convexiusculo; dorsali utrinque leviter declivi; extremitate anticâ rotundatâ ; posticâ subattenuatâ, angulatâ ; superficie internâ albidâ, umbones versus aurantio tinctâ; dentibus lateralibus validis, subæquidistantibus.

Oblong, solid, moderately convex, subequilateral, rayed with pale crimson red and yellow, concentrically sulcated; sulci fine and terminated at either extremity and near the little arcuated ventral margin, by sublunate scales, which in some specimens become more elevated and somewhat tongue-shaped; dorsal slopes gentle; anterior extremity rounded; posterior rather attenuated; lateral teeth very strong, and nearly equidistant.

Var. a. More elongated, sulci and scales stronger and more numerous. Var. $b$. Sulci very fine and rather oblique; scales visible along the ventral margin.

Singapore, and Straits of Banca (Cuming). 1844 .

9. Tellina asperrima (pl. lx. f. 135.) Hanley, Zool. Proc.,

T. testâ oblongo-ellipticâ, convexiusculâ, solidiusculâ, flavidâ aut incarnatâ, roseo-radiatâ; totâ superficie extemâ squamis asperrimâ; squamis auticè sublunatis, posticè (et præsertim supra costam umbonalem distinctam) spinosis; margine ventrali medio subrecto, flexurâ distinctâ ; dorsali utrinque subdeclivi, et paululum convexi- 
usculo; latere antico breviore; extremitate posticâ subbiangulatî, attenuatî; dentibus lateralibus magnis, antico approximato.

Oblong-elliptic, moderately convex, rather solid, flesh-coloured, with dull crimson rays, the entire surface rough with tooth-like scales, which become morc crowded at the rounded anterior extremity, and between the distinctly indicated umbonal ridge and the nearly straight posterior edge rise into rather distant elevated fangs; slopes gentle; posterior side the longer, its extremity angulated; ventral edge nearly straight; teeth very distinct, the lateral large, the anterior lateral approximate, The scales are replaced near the beaks by raised concentric striæ.

An unique specimen, in the cabinet of Mr. Cuming, was found by him at Sual, province of Sangasinan, Isle of Luzon (sandy mud, six fathoms). Allied to Pulcherrima.

10. Tellina sulcata (pl. 60. f. 138.) Wood, Gen. Conch. p. 178. t. 47. f. 1; Hanl. Des. Cat., t. 4. f. 63; Dilw. p. 89.

T. testâ ovali-subtrigonâ, solidâ, subcompressâ, subæquilaterali, subimpolitâ, albidâ aut flavescente, concentricè sulcatâ et radiatim striatâ; sulcis elevatis, subconfertis, ad costam umbonalem prominentem rudioribus; flexurâ conspicuâ ; margine ventrali convexo ; dorsali utrinque (et præsertim posticè) declivi, anticè subrecto, posticè recto ant subincurvato ; latere postico leviter subrostrato, attenuato; extremitate posticâ biangulatâ ; superficie internâ flavidâ ; dentibus lateralibus validis, subæquidistantibus.

Oval-subtriangular, solid, rather depressed, subequilateral, rather dull, white or pale straw coloured, with regular rather close raised concentric sulci, which become sublamellar on the prominent umbonal ridge; the interstices with radiating strix; ventral edge convex; flexure conspicuous; anterior dorsal slope gentle, and nearly straight; posterior side attenuated, its dorsal slope straight and rather strong, its extremity biangulated; inside yellowish; lateral teeth strong and nearly equidistant.

A small specimen was procured by Mr. Cuming, at Catbalonga, Isle of Samar.

- 11. Tellisa interrupta (pl. lxiii. f. 207.) Wood, Gen. Conc. (1815), p. 146. t. 36. f. 3 ; Dilw. 75 . T. maculosa, Lam. (1818) no. 4; Chem. vol. vi. f. 73 ; Enc. Mèth. t. 288. f. 7.

T. testâ ovali ant ovali-oblongâ, æquilaterali, solidâ, subventricosâ, impolitâ, albâ, lineis undosis angularibus lividis brunneis fulvis aut purpureis nebulosâ aut subradiatâ; concentricè sulcatâ, sulcis posticè membranaceis ; margine ventrali subarcuato; dorsali utrinque declivi et convexiusculo ; latere postico attenuato, subros- 
trato; extrcmitate posticî angulatî ; costâ umbonali prominente; natibus plerumque purpureis ; umbonibus flavis; ligamento magno; superficie internâ flavidâ; dentibus lateralibus magnis, subæquidistantibus.

Var. Testâ angustiore; sulcis remotioribus; margine ventrali rectiore, dorsali utrinque minus declivi.

Oval or oval-oblong, equilateral, solid, subventricose, not polished, white crowded with narrow zigzag linear streaks of fawncolour brown chocolate or purple, beaks usually tipped with purple, umbones yellowish; surface with moderately distant raised concentric sulci, which become more elevated but not thickened on the conspicuous umbonal ridge; ventral edge moderately arcuated; anterior side rounded at its extremity, the dorsal slope gentle; posterior side attenuated, subrostrated, the slope strong and very slightly convex, the tip obtusely angulated; inside tinged with yellow ; lateral teeth very strong, subequidistant.

Var. Narrower and more elongated; dorsal edges less sloping; ventral edge straighter; sulci rather more distant.

Surinam. The T. Mexicana of the 'Revue Cuverienne,' is now regarded by its author as an elongated variety of this species.

- 12. Tellina virgata (pl. lxiii. f. 212.) Lin. Sys., p. 1116; Chem. vol. vi. f. 67 ; Enc. Mèth. t. 288. f. 2 ; Mawe's Conch. t. 6. f. 1 ; Lam. no. 5 ; Hanl. Des. Cat. p. 61. t. 3. f. 3; Wood, Gen. Conc. t. 35 . f. 2,3 .

T. testâ ovali, subtrigonâ, solidâ, convexiusculâ, subæquilaterali, flavâ, roseo-purpurascente radiatâ, concentricè sulcatâ,; sulcis anticè subimbricatis, posticè rudioribus magisque elevatis ; margine ventrali posticè sursum acclinato, medio subrecto, anticè arcuato, carinâ umbonali prominente; latere antico breviore, rotundato; postico attenuato, subrostrato ; margine dorsali postico elongato, declivi, subincurvato; ligamento magno; superficie internâ aurantio tinctâ; dentibus lateralibus validis, subæquidistantibus.

Oval, subtriangular, solid, moderately convex, nearly equilateral, rich yellow, either uniform, or closely rayed with dull purplish crimson; the concentric sulci becoming closer and slightly imbricated anteriorly, and coarser more prominent and distant as they approach the projecting umbonal ridge; ventral edge subarcuated in front, nearly straight in the middle, and sloping up towards the attenuated and subrostrated posterior extremity; ligamental edge somewhat incurved, much sloping; ligament large and promiment; within usually tinged with orange, the lateral teeth strong and subequidistant.

Indian Ocean. 
- 13. Telinina jubar (pl. lxiii. f. 214.) Hanley, Zool. Proc.1844. T. virgata, var. Wood, Gen. Conc. t. 36. f. 2. Enc. Mèth. t. 288. f. 4 . (bad).

T. testî specie priore magis triangulari, altiore, minus elongatâ; rubro-purpureâ, radiis albis ant albidis ornatî; margine ventrali subarcuato; dorsali utrinque decliviore; superficie internâ albidâ, aut coloribns externis fucatî.

Extremely like Tirgata, but more triangular and less elongated, the dorsal slopes being more suddcn; the ventral edge is more convex, and less straight in the middle; the external colouring of broader and narrower white rays on a dull rosy or reddish ground, is frequently visible on the otherwise white surface of the interior.

Mus. Cuming.

The ligamental margin inclines to convexity, which is the reverse of what we meet with in Firgata and Marginalis.

14. Telluna marginalis (pl. lxiii. f. 216.) Dilw. Des. Cat. p. 74 ; Chem. f. 68 , (tolerable).

T. testâ Virgatæ et Jubaris maximè assimili, altiore autem, magisque rotundatâ ; margine ventrali planè arcuato, posticè sursum acclivi; dorsali utrinque leviter declivi; superficie extcruâ albidâ, radiis rubescentibus ornatâ.

Closely allied to the two preceding, but less oblong than either; the ventral edge much more arenated, and ascending abruptly on the posterior side; the ligamental edge sloping, but slightly and somewhat concavely; the colouring whitish, with pale rosy-red or deep flesh-coloured rays; interior nearly white.

Indian Ocean? \&c.

15. Telitina staurelia (pl. lx. f. 148. and pl. lxi. f. 171. and pl. lxv. f. 261.) Lam., no. 6; Hanl. Des. Cat. p. 61 . sup. t. 11. f. 33 ; Delessert, t. 6 . f. 2 ; Chem. vol. vi. f. 70 , 71 ; Philip. Ab. und Bes. Conch. part v. t. 5. f. 6. T. scalaris, Lam. 110. 29.

T. testâ ovali ant oblongo-ovali, solidâ, convexâ, niticlâ, extus intusque albidâ aut flavidâ, radiis angustis roseis confertis plerumque ornatâ ; concentricè sulcatâ, sulcis anticè subobliquis et subimbricatis, posticè submembranaceis et paucioribus (plerumque in valrulâ alterâ omnino obsoletis) ; margine ventrali convexo ; dorsali anticè subdeclivi et vix convexiusculo, posticè declivi et subrecto; latere antico manifestè longiore, postico attenuato; extremitate posticâ obtusè angulatâ; natibus plerumque roscis, nonnunquam cruce roseo-rubrẩ notatis ; ligamento magno, subconspicuo; dentibus lateralibus magnis, subrequidistantibus. 
Oval or oblong-oval, solid, convex, glossy, white or yellowish, with narrow pink or rosy rays (which often become obsolete,) and concentric sulci, which, subimbrieated in front, are almost lanellar towards the decidedly shorter posterior side, where in one valve they almost always become obsolete; dorsal slopes rather gentle; ventral edge convex; posterior extremity attenuated and angulated; umbonal ridge distinct; inside whitish or tinged with yellow, beaks tinged with rose-colour; lateral teeth strong and nearly equidistant.

Var. $a$, with two short rays at the beak in each valve, forming a small crimson cross; a smooth posterior area in one valve. Var. $b$, beaks with a very large crimson cross; no rays; sulci finer; area as in last. Var. $c$, rays distinct; no smooth area. Var. $d$, As last, but perfectly white, and oval-oblong.

T. scalaris is but an abbreviated variety of this very variable species, with the posterior side more strongly biangulated and less attenuated at the extremity. The typical specimen of the French Museum is yellow, (externally very pale) with the apical cross of a rich red and very small.

Philippines \&c., very common. 1814 .

16. Tellina Guildingit (pl. lvi. f. 1.) Manley, Zool. Proe.

T. testî oblongâ, tenui, compressâ, subæequilaterali, albidâ, radïs aurantio-roseis zonisque albido-roseis ornatâ; sulcis exilibus confertis coneentricè exaratâ; margine ventrali subrecto, medio subretnso ; dorsali utrinque deelivi, et vix convexiuseulo ; latere postico paululum breviore, attenuato ; extremitate posticâ infernè angulatâ, anticâ rotundatî; natibus acutis; costâ umbonali et flexurâ ventrali inconspicuis ; ligamento prominente ; dentibus lateralibus magnis, requidistantibus.

Oblong, thin, compressed, subequilateral, whitish, with narrow roseate flesh-colonred rays, and fine close-set coneentric sulci ; ventral edge nearly straight, rather retuse in the middle; dorsal margin searccly at all convex or sloping on cither side; posterior side very slightly the shorter, attenuated, its extremity angulated below (biangulated in the young, and the ligamental edge retuse) ; anterior end rounded ; umbonal ridge obsolete ; flexure inconspieuous; ligament prominent; inside pale; lateral teeth large, and equidistant.

West Indies.

17. Teldina pulchelia (pl. lvi. f. 4.) Lam., no. 23 ; Hanl. Des. Cat. p. 64. sup. t. 1. f. 4 ; Philip. Eir. Mol. Sicil. rol. i. p. 2.4. 
T. rostrata, Born. t. 2. f. 10 ; Poli. 'Tes. Sic. vol. xv. f. S ; T. virgata, var. Chem. vol. vi. p. 72.

T. testî oblongî, angustâ, tenui, compressî, niticlâ, radiis roseis vel roseo-aurmtiis ct albidis vel flavidis eleganter ornatâ, striis confertis exilibus concentricè sulcatî ; margine ventrali subrecto ; latere antico producto, rotundato; postico breviore, valde attenuato, subrostrato ; margine dorsali anticè paululum declivi, posticè vilde declivi, convexo, intusque roseo; nutibus albidis; superficie interuâ albido-rosê̂ ; dentibus lateralibus validis, antico subapproximato.

Var. testî omuino roseâ.

Elongated-oblong, very thin, compressed, glossy, rayed with rosecolour and white, the former often passing into orange, the latter tinged usually with yellow; more rarely of an uniform rose-colour, except the tips of the beaks which are always pale or whitish ; most delicately but regularly and closely striated concentrically; ventral edge nearly straight; anterior side produced, its slope very gentle, its extremity rounded; posterior side shorter, much attenuated, subrostrated, the dorsal slope great but convex; inside pink, ligamental edge rosy; lateral teeth strong, anterior one subapproximate.

Mediterrancan.

\section{4 .}

18. Tellina virgulata (pl. lvi. f. 5.) Hanley, Zool. Proc.

T. testâ Donacince simillimâ, sed panlulum angustiore, striisque exilioribus ornatâ ; cxtus intusque albilâ, roseo-radiat haud interruptis; matrgine dorsali anticè albido.

Extremely like Donacina, but the shape is slightly narrower, the striæ more delicate, and the colouring consists of a few interrupted rose-coloured rays upon a white ground; the interior dorsal edge is white.

Mus. Cuming.

19. Tellina distorta (pl. lvi. f. 6.) Poli, Test. Sic. vol. i. t. 15. f. 11 ; Philip. Mol. Sic. vol. i. p. 25.

T. testî ovato-oblongî, compressiusculî, temi, nitidâ, subpellucidî, pallidè rosêt aut aurantio-rosê̂, radiis saturatioribus plerumque pictâ ; concentricè striat $\hat{u}$, striis minimis et posticè elevatis ; margine vent rali convexinsculo; clorsali nt ringue subrecto, anticè minimè declivi; latere antico longiore, ad extremititem obtusè rotındato; extremitate posticâ cunciformi, paululum subrostratî ; flexurâ coštâtque umbonali subincouspienis; ligamento parvo, satis prominente; dcutibus lateralibus distinctis, postico subremoto. 
Ovate-obloug, slightly compressed, thin, subpellucid, glossy, pink or rosy orange, with narrow deeper-coloured rays, crowded with minute concentric striæ which become more distinct and elevated posteriorly; ventral margin slightly convex; anterior side the longer, obtusely rounded at its extremity, its dorsal edge scarcely at all declining; posterior extremity wedge-sliaped, the ligamental edge nearly straight; ligament small but not sunken; fold and flexure not conspicuous; lateral teetll distinct, posterior the more distant.

\section{Mediterranean.}

-20. Tellina doxacisa (pl. lvi. f. 12. and pl. lxvi. f. 259.) Lin., Sys. 1118; Lin. Trans. vol. viil. t. 1. f. 1. ; Mont. Test. Brit. t. 27. f. 3; Turt. Biv. Brit. p. 103. t. 8. f. 4 ; Wood, Gen. Conc. t. 45. f. 5; Plilip, En. Mol. Sic. vol. i. p. 24; Lam. no. 27 ; Hanl. Des. Cat. p. 64. t. 4. f. 31 . T. variegata Poli, vol. i. t. 15 . f. 10. T. Llantivyi, Payj. Cat. Cors. p. 40. t. 1. f. 13, 14.

T. testâ oblongâ, solidiusculâ, subconvexî, impolitâ, albido-flavescente, radiiis roseo-rubris angustis interruptè ormatâ, striisque subimbrieatis coucentricè sulcatâ; margine ventrali convexiusculo, et anticè arenato ; margine dorsali roseo, auticè minimè posticè subito, deelivi; latere antico latitudinem postici cluplo superante; extremitate anticâ rotundatâ, postieâ obtusissimè cuneiformi ; natibus radio brevi recto roseo strigatis ; superfieie internâ flavescente, prope nates rosco-tinctî; dentibus lateralibus validis, subæquidistantibus.

Var. Penitus candidâ.

Oblong, rather solid, moderately convex, rather dull, pale yellow, with crimson interrupted narrow rays, and concentric subimbricated strix; ventral edge moderately convex, swelling out anteriorly ; dorsal edge rosy; beaks with a sliort direet rosy streak; anterior side thrice as long as the posterior, its extremity rouncled, its dorsal edge nearly horizontal; posterior side very short, most obtusely cuneiform, inside tinged with yellow, becoming pink near the beaks, teeth strong, subequidistant.

Var. Perfectly white.

Britain, Lurope.

21. Teluiva tulipa (pl. lvi. f. 25.) Hanley, Zool. Proe. 1844.

T. testî ovali-oblongâ, solidâ, subinæquilaterali ,compressâ, nitidiusculî, lineis elevatis concentricè et confertim striatâ ; albidâ aut albido-roseâ, radiis roseis multis angnstis subinterruptè ornatâ; margine ventrali medio retuso; dorsali utrinque subrecto, anticè vix paululum declivi, posticè satis declivi; latere antico paulo lon- 
giore, ad extremitatem obtusè rotundato; postico truncato-cuneiformi; liganiento prominente; costî umbonali subobsoletâ; dentibus ut in Donaciná.

Oval-oblong, solid, slightly inequilateral, compressed, somewhat glossy, with very close concentric striæ, which are subimbricated in front, and raised behind; white or pale pink, with numerous rosy somewhat interrupted rays; ventral edge subretuse in the middle; dorsal edges nearly straight, the front one scarcely, the hinder one moderately sloping; ligament prominent; anterior side rather the longer, and obtusely rounded at its termination; posterior side of a truncated wedge-shape; umbonal ridge not prominent ; inside paler than the exterior but usually tinged with rose-colour; teeth as in Donacina.

Mus. Cuming, Walton.

22. Tellina lineata (pl. lvi. f. 35, 36. and pl. lvii. f. 46, 47.) Turton, Conch. Dict.p. 168. f. 16 ; Turt. Biv. Brit. p. 99. t. 7. f. I. T. Brasiliana Lam. no. 46 ; Hanl. Des. Cat. p. 70. sup. t. 9. f. 3. T. striata Mont. Test. Brit. p. 60. t. 27. f. 2 .

T. testâ ovatâ, solidâ, convexâ, concentricè et confertissimè striatâ; margine ventrali medio subrecto; dorsali anticè magis minusve convexo et paululum declivi, posticè umbones versus subretuso, deinde convexo et declivi; latere antico longiore, ad extremitatem rotundato ; extremitate posticâ cuneiformi; ligamento prominente; flexurâ costâque umbonali satis conspicuis; dentibus lateralibus validis, subæquidistantibus.

Var. $a$, Testâ sordidè albidâ, umbonibus nonnunquam aurantiis, radioque brevi obliquo roseo anticè ornatis. Var. b, Penitus candidâ. Var. c, Ovato-oblongâ, lævigatâ, nitidâ, albido-roseâ, radio obliquo ut in var. $a$; intus roseâ.

More or less ovate solid and convex, with concentric minute crowded strix; the ventral margin nearly straight in the middle; anterior side the longer (sometimes scarcely so,) its extremity rounded, its dorsal edge but slightly sloping; posterior extremity wedgeshaped, the ligamental edge, which near the beaks is somewhat retuse, becoming convex at its termination; fold and flexure inconspicuous; lateral teeth strong, and subequidistant.

Var. $a$, Pale, with a short oblique anterior crimson ray at the umbones, which are sometimes tinged with orange. Var. b, Entircly white. Yar. $c$, The ray as in var. $a$, but the shape more elongated, and the surface pink smootl and glossy; inside rosy.

Britain (?), West Indies, Florida, and Brazil. 
There being a previous Brasiliana, the subsequent name of 'Turton must be adopted.

\section{Teldina gelida, Hanley.}

T. testâ ellipticâ, æquilaterali, solidiusculâ, subinæquivalvi, convexiusculâ, subnitidâ, intus extusque candilâ, lineis clevatis concentricis subconfertim striatâ, striis anticè ct posticè elevatioribus; margine ventrali convexo; dorsali utrinque subdeclivi, subrecto, anticè lamellis lanceolatis dentato; natibus haud incumbentibus; extremitate anticâ rotundatâ; posticâ subbiangulatâ, costâ umbonali distinctâ; ligamento infosso; dentibns lateralibus subæuuidistantibus.

Elliptic, equilateral, slightly inequivalve, tolerably strong, moderately convex, scarcely glossy, white both within and without, with elevated and rather close concentric lines, which are stronger at the extremities, interstices quite smooth; ventral edge convex; dorsal but moderately sloping on either side, nearly straight, dentated in front by lanceolate lamellæ; beaks not inclining; front extremity rounded, hinder one somewhat biangulated ; fold distinct ; ligament sunken; lateral teeth nearly equicistant.

Mus. Belcher.

Unfortunately a figure of this distinct species canmot be given, as the possessor of the unique specimen is not in England.

24. Tellina serrata (pl. lxv. f. 256.) Costa, p. xvi. no. 8 ; Philip. En. Mol. Sic. p. 25 ; A b. und Bes. Concl. jart 5. t. 5 f. 5.

T. testâ ovali-trigonâ, solidiusculâ, satis convexâ, inæquilaterali, nitidiusculâ, intus extusque albidâ, (umbonibus plerumque flavis ;) concentricè striatâ, striis exilibus, confertissimis, anticè posticè et infernè subelevatis; margine ventrali convexiusculo; clorsali anticè convexiusculo vixque declivi, postico subrecto et valdè declivi; latere antico longiore, ad extremitatem rotundato; posticè cunciformi ; costâ umbonali satis conspicuâ; natibus acutis ; ligannento infosso; dentibus lateralibus, magnis, haud remotis, subrequidistantibus.

Subtriangularly oval, tolerably solid and convex, inequilateral, slightly glossy, within and without whitish, with the umbones usually bright yellow, most closely and delicately striated; the strix raised at the extremities and towards the moderately convex ventral margin; front dorsal edge moderately convex and not much sloping, hinder one straightish and considerably sloping; front side the longer, its extremity rounded; hinder side wedge-shaped; fold 
distinct; beaks acnte; ligament sunken; lateral treth large, tolerably and almost equally closc.

Mecliterrancall.

25. Teulina Owenir (pl.lx. f. 133.) Ilanley, Zool.Proc.1844.

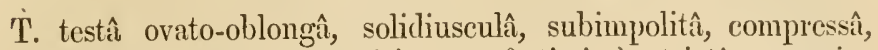
xqunilaterali, albidâ, concentricè ct confertissimè striatî ; margine ventrali valdè arcuato ; dorsali utrinque subdeclivi, anticè subrecto, posticè incurvato ct lamellis subdentato ; extremitate anticâ rotuudatî; latere postico acumiuato, subrostrato; costâ umbonali conspicuâ; flexurâ satis distinctî; natibus acutis ; ligamento infosso; disco interno aurantio; dentibus lateralibus, subrcmotis, subæquidistantibus.

Ovate-oblong, tolerably strong, rather dull, whitish, (with often a tinge of orange in the front part of the umbones, and the intermal disc always of that colour,) equilateral, compressed, with crowded concentric strix; ventral elge much arcuated; dorsal moderately sloping on either side of the acute beaks, nearly straight in front, incurved behind and somewhat toothed by the lamellæe, (which in some specimens commence before the conspicuous fold); ligament sunken; lateral teeth distinct, and nearly equally remote.

Africa.

26. Telitna pharaonis (pl.lxiii. f. 215.) Hanley, Zool.Proc. 1844.

T. testâ T. Fulsella simillimâ, sed solidâ lineisque clevatis concentricè striatâ, umbonibus anrantio-roscis ; flexurâ sinuatâ.

Extremely like T. Tulsella, but solid, and rough with concentric clevated strix ; fold sinuated.

In the only specimen $I$ have ever seen, one of the valves is of a delicate pink, the other white tinged with the same line, the beaks of a very rosy orange and the ventral flexure so deep as to form a sinus; the lower margin is not so convex in front as in Rostrata; the front lateral tooth is distinctly crenated, but this is probably accidental.

Red Sea.

27. Telunva vulselita (pl. lxi. f. 162, 163.) Chem. T. rostrata, Gmel. p. 3233 (in part); Dil. Des. Cat. p. 84; Lam. no. 9 ; Chem. vol. vi. f. 105 ; Enc. Mètl. t. 289. f. 1 ; Woorl, Gen. Conc. t. 37. f. 3; Knorr. vol. iv. t. 2. f. 2, 5; Hanl. Des. Cat. p. 62. t. 4. f. 28 .

T. testâ valdè elongatî, compressî, tenui, subpellucidâ, nitidis- 
simâ, sublævigatâ, roseâ, radio pallidiore postico plerumque notatâ ; margine ventrali anticè arcuato, posticè flexuoso et sursum acclinato; dorsali utrinque vix minimè declivi, prope nates acutas subretuso, deinde subrecto aut paululum convexiusculo ; latere antico longiore, ad extremitatem rotundato; postico angusto, acuminato, rostrato ; ligamento infosso; flexurâ costâque umbonali conspicuis; dentibus lateralibus parvis, tenuibus, æquidistantibus.

Var. Flavo-aurantiâ.

Much elongated, compressed, thin, subpellucid, polished, rosecoloured, with usually a paler posterior ray, nearly smooth, or with minute radiating and concentric strix; ventral edge arcuated in front, flexuous and greatly elevated behind; dorsal edge scarcely at all sloping in front, rather more so posteriorly, subretuse near the acute beaks, and then straightish or very slightly convex; anterior side the longer, rounded at its extremity; posterior side forming a narrow acuminated beak; ligament sunken; fold and flexure conspicnous; lateral teeth thin, small, and equidistaut.

Var. Rich yellow.

Yellow var. Isle of Zebu.

As this is not the Rostrata of Linnæus, I have adopted the other name proposed by Chemnitz "Rostrata seu Tulsella".

28. Telliva perna (pl. lxiii. f. 202, 217, 219.) Spengler, Schrivt. Naturhis. Gelstav. Kiobenha. 4. (1798). T. pallescens Dil. Des. Cat. p. 84. T. sulphurea and latirostra Lam. no. 10, 11. Hanl. Des. Cat. p. 62. T. incarnata Born p. 36. t. 2. f. 12. (erroneously quoted as 11 in text). T. rostrata flavescens Chem. vol. vi. f. 104. T. latirostra, Swain. Zool. Ill. 2nd ser. vol. i. t. 20.

T. testâ oblongo-elongatâ, tenuiusculâ, convexâ, subpellucidâ, nitidâ, sublærigatâ, albâ, flavâ, aurantiâ ant roseâ, radio pallidiore postico plerumque ornatâ ; margine ventrali anticè arcuato, posticè sursum declivi; dorsali anticè vix declivi, convexiusculo, posticè paululum declivi, prope nates conspicuas subincurvato, mox convexiusculo; latere antico longiore, subproducto; postico rostrato; extremitate posticâ obtusè angulatâ ; umbonibus subtumidis ; ligamento infosso; margine cardinalis interno, angusto, callo ligamentali munito; dentibus lateralibus tenuibus, inconspicuis, æquidistantibus.

Elongated-oblong, rather thin, semitransparent, convex, glossy, very variable in colouring, being sulphur-yellow, white, pink with or without paler rays, orange with white rays, or orange flesh-coloured, \&c., nearly smooth, often with obsolete radiating striulæ, which are more cvident posteriorly; ventral edge arcuated in front, 
curving up posteriorly; anterior side rather the longer, its extremity obtusely rounded, scarcely any dorsal slope, but the edge convex; posterior side beaked, its dorsal edge moderately sloping and convex at its termination, its extremity obtusely subangulated; umbones ratler tumid; ligament sunken; hinge-margin narrow, a callus near the tecth; lateral teeth thin, equidistant, indistinct.

Singapore, Isle of Burias, \&c.

29. Telliva albinella (pl. lxi. f. 164, 166.) Lam., no. 17 ; Hanl. Des. Cat. p. 63. sup. t. 14. f. 3.

T. testâ oblongo-ovali, subæquilaterali, tenuiusculâ, complanatâ, nitidiusculâ, extus intusque albidâ; alterâ valvulâ sublævigatâ, alterius areâ posticâ concentricè striatâ; margine ventrali vix convexiusculo; dorsali anticè arcuato et declivi, posticè declivi et subincurvato; ligamento infosso; flexurâ subinconspicuâ; costâ umbonali carinatấ; dentibus lateralibus perparvis, inconspicuis, antico approximato. Var. Roseâ.

Oval-oblong, rather thin, flat, subequilateral, slightly glossy, whitish, (usually with a fulvous stain towards the beaks,) nearly smooth, except on the posterior lialf of one of the valves which is deeply and distinctly striated concentrically; ventral edge nearly straight in the middle and rising behind; front dorsal edge arched and deeply sloping; posterior side acuminated, angulated below, and slightly beaked, the ligamental edge moderately sloping, and rather incurved; ligament sunken ; inside whitish, the lateral teeth very small, indistinct, the anterior one closely approximate.

Var. Rose-coloured.

Australia.

30. Tellina rosea (pl. lxi. f. 170) Spengler, Schriv. Natur. Gelsta.Kioben. vol.4. 1798; T.pallidè rosea, Chem. vol.6. f.96.

T. testâ oblongâ, crassissimâ, subæquilaterali, convexiusculâ, nitidâ, roseâ, sublævigatâ, striis concentricis tenuissimis, lineisque radiantibus obsoletis tantum signatâ; striis posticis prope nates acutas remotis, subelevatis; margine ventrali convexo, posticè acclivi; dorsali utrinque declivi, anticè convexo, posticè subrecto plerumque subincurvato; latere postico subcuneiformi ; extremitate posticâ subacuminatâ ; costâ umbonali angustâ ; flexurâ inconspicuâ; ligamento infosso ; superficie internầ roseâ, politâ, impressionibus muscularibus fortiter impressis; margine cardinali intus lato, valido; dentibus lateralibus parvis, subæquidistantibus, æatate obsoletis.

Oblong, very solid, subequilateral, rather convex, glossy, pink, 
with delicate concentric and obsolete radiating striæ, the posterior concentric more distant raised and distinct near the beaks; ventral edge scarcely arcuated, ascending posteriorly; anterior side rounded, its dorsal slope strong; posterior side wedge-shaped, ligamental edge nearly straight, often slightly incurved, moderately sloping, point acuminated; within rosy, polished, scars deeply impressed; hinge margin broarl and very strong; lateral teeth subequidistant, rather small, by age obsolete.

Indian Ocean (?).

31. Telitina inequistriata (pl.1vii.f.58. and pl.lviii. f. 80. ) Donoran, Brit. Shells, (1802), vol. 4. t. 123; T. sanguinea, Wood, Gen. Conch. p. 159. t. 44. f. 2 ; Hanl. Desc. Cat. p. 67. t.4. f. 27.

T. testâ oblongo-subtrigonâ, solidiusculâ, subæquilaterali, nitidâ, compressiusculâ, pallidè rubro-sanguinen̂, concentricè confertim et exilissimè striatâ; strïis posticis alterâ in valvulâ remotis, rudioribus; margine ventrali subrecto; dorsali anticè convexiusculo et subdeclivi, posticè declivi et urope nates retuso ; latere antico paulo longiore, ad extremitatem rotundato ; postico truncato-cuneiformi; colore intemo saturatiore; ligamento prominulo; flexurâ costâque umbonali olısoletis; dentibus lateralibus magnis, antico approximato, postico haud remoto.

Var. a, striis posticis in ntrâque valvulâ remotis, rudioribus. Var. $b$, testî albidâ, pallidè aurantio ad nates utrinque radiatâ.

Oblong, very slightly triangular, rather solid, somewhat compressed; glossy, subequilateral, of a pale blood red, with fine and crowcled concentric strix, which however in one of the valves are posteriorly replaced by coarser and more distant ones; ventral edge nearly straight; anterior side rather the longer, its end rounded, its dorsal slope moderate and tolerably convex; posterior end truncated-cuneiform, its dorsal slope strong, nearly straight, or somewhat concave near its acute beaks ; ligament but slightly projecting; fold and flexure obsolete; internal colours deeper; lateral teeth large, the posterior not very distant, the anterior subapproximate.

Var. $a$, the posterior strix distant in both valves. Var. $b$, white, with a short pale orange ray on either side of the beaks.

In sculpture resembling Nitida.

Bay of Guayaquil ; (Cuming). 1844.

32. Tellina Princeps (pl. lxiii. f. 206.) Hanley, Zool. Proc.

T. testâ oblongo-ellipticâ, æquilaterali, solidâ, compressâ, nitidiusculâ, intus extusque roseo-purpurascente, concentricè sulcatâ; striis exilibus, profundis, radiantibus, sulcos confertos, utrinque (et 
alterâ in valvulâ undique) decussantibus; margine ventrali subrecto; dorsali utrinque leviter et æqualiter subdeclivi; extremitate posticâ obtusissimè angulatâ; flexurâ ventrali costâque umbonali, obsoletis ; ligamento prominente ; dente laterali antico approximato et conspicuo, postico parvo, remoto, inconspicuo.

Oblong elliptic, equilateral, solid, compressed, rather glossy, both internally and externally of an uniform reddish lilac colour, the surface decussated by close-set concentric sulci and fine but very distinct radiating striæ, which are only visible at the extreme sides in one of the valves; the ventral edge nearly straight; the dorsal slopes gentle and all but equal; the posterior end nost obtusely angulated; umbonal ridge and flexure obsolete; the anterior lateral tooth extremely close and distinct, the posterior very distant and inconspicuous.

Not readily confused with any in this division, but very closely allied to Purpurascens, from which the teeth distinguish it.

Tumbez, Peru; (Cuming).

33. Telitina punicea (pl. lviii. f. 89. and pl. Ix. f. 154.) Born, p. 33. t. 2. f. 2 ; Lam. no. 21 ; Enc. Mèth. t. 291. f. 2 ; Gmel. 3239 ; Dil. Des. Cat. p. 90.

T. testâ ovali-trigonâ, solidâ, convexiusculâ, subæquilaterali, nitidâ, extụs intusque albido-roseâ, (rarius candidâ) prope nates albas colore saturatius tinctâ; concentricè sulcatâ, sulcis confertis, noununquam alterâ in valvulî posticè obsoletis; margine ventrali convexiusculo; dorsali utrimque declivi, anticè convexiusculo, posticè subrecto ; extremitate anticâ obtusâ, et supernè subemarginatâ ; latere postico truncato-cuneiformi : flexurî costâque umbonali inconspicuis; ligamento prominulo aut prominente; dentibus lateralibus distinctis, antico valdè approximato, postico remoto.

Var.? Magis trigonâ, tenuiore, saturatius pictâ, sulcis alterius valvulæ posticè obsoletissimis, emarginatione subobsoletâ.

Subtriangularly oval, solid, moderately convex, nearly equilateral, glossy, of a pale rose-colour, increasing in intensity near the whitetipped beaks; surface closely and deeply grooved (the sulci rarely obsolete belind) ; ventral edge slightly convex; mterior side (if either) the shorter, the extremity obtusely emarginated or indented near the dorsal slope, which is shight and rather convex; posterior side of a truncate wedge shape, its dorsal edge nearly straight and much sloping; fold and flexure obsolete; ligament always more or less prominent; lateral teeth distinct, the front one approximate, the hinder remote.

Var.? more triangular, thimner, deeper coloured ; the sulci pos- 
teriorly quite obsolete in one of the valves; emargination almost obsolete.

Xipixapi, W. Columbia, in sandy mud, 10 fathoms (Cuming); and Trinidad, W. Indies; Britain (?).

Easily distinguished from Striata, by its closer and more delicate sulci, its less prominent beaks, and the absence of all radiation. It is also thicker and more opaque, and remarkable for the slight indentation which terminates the rather flattened space adjacent to the front dorsal edge, a character which is not possessed by any of the allied species.

34. Telurya striata (pl.lxi.f.161.) Chemn., vol.x. p. 349 . f. 1654-5; T. angulosa, Gmel. 3244 ; T. læta, Montagu, Test, Br. p. 57 ; T. punicea, in part, Turt. Dic. ; Donax Martinicensis. Lam. (fide Deles. Rec. t. 6. f. 15.)

T. testâ ovali-subtrigonâ, solidiusculâ, subpellucidâ, convexiusculâ, nitidâ, aut albido-roseâ radio roseo utrinque ornatâ, aut albidâ radio flavescente; concentricè sulcatâ, sulcis remotis, alterâ in valvulâ posticè evanescentibus ; margine ventrali paululum convexiusculo; dorsali utrinque declivi, anticè convexiusculo, posticè subrecto; latere antico longiore, postico truncato-cuneiformi; extremitate anticâ simplici, rotundatâ; flexurâ costâque umbonali inconspicuis ; natibus acutis, pallidis ; ligamento prominente; dentibus ut in Puniceâ.

Subangularly oval, moderately solid and convex, either pale pink with a roseate ray down the obsolete umbonal ridge (preceded by a paler streak) and a short roseate ray in front of the acute and prominent beaks, or white with the rays yellowish; surface grooved by subimbricated distant sulci, which disappear on one of the valves at the truncate wedge-shaped hinder extremity; ventral edge but slightly convex; anterior side the longer, its extremity simply rounded and never indented, its dorsal edge but moderately sloping and slightly convex; hinder dorsal edge sloping and nearly straight; flexure nearly obsolete; teetl as in Punicea.

W. Indies ; Britain (?).

The rays are never absent, and the anterior side is always the longer. Mr. Sowerby informs me, that this is the Tellinides rosacea of King (Zool. Journ. vol. 5.), which is too briefly defined for recognition.

Tellina regia (pl.lx. f. 140.) Ilanley, Zool. Proc. 1844.

T. testâ oblongâ, tenui, compressiusculâ, subinæquivalvi, subæquilaterali, nitidissimâ, pellucidâ, intus extusque roseo-purpuras- 
cente; concentricè sulcatâ, sulcis remotis, alterâ in valvulâ posticè evanescentibus; margine ventrali subrecto, medio subretuso; dorsali utrimque subæqualiter declivi, posticè subrecto; latere antico paululum breviore, ad extremitatem obtusè rotundato ; extremitate posticâ supernè angulatâ, attenuatâ; costâ umbonali et flexurâ ventrali obsoletis; ligamento prominulo; dentibus ut in Puniceâ.

Oblong, thin, rather compressed, almost inequivalve, subequilateral ; extremely glossy, both externally and internally of a deep subpellucid purplish crimson; the surface marked with distant concentric grooves, which posteriorly become obsolete in one or both of the valves; the ventral edge nearly straight, subretuse in the middle; anterior side slightly the shorter, its extremity obtusely rounded; posterior extremity almost biangulated; dorsal moderately and almost equally sloping on either side of the beaks, nearly straight posteriorly; umbonal ridge and flexure nearly obsolete; the ligament rather prominent; teeth as in Punicea.

Most closely allied to Punicea, but its deep purplish red, and its more distant sulci suffice to distinguish it. From Princeps it differs by the absence of radiating strix; from Striata, by its slightly longer posterior side; from Rubescens, by its colouring, and the lesser slope of the dorsal edges.

Real Lileijos, Central America.

36. Tellina eburnea (pl. lviii, f. 91.) Hanley, Zool. Proc. 1844. p. 61 .

T. testâ oblongâ, opacâ, solidâ, inæquivalvi, convexâ, nitidâ, albidâ, inæquilaterali ; concentricè sulcatâ, sulcis profundis, remotis, (alterâ in valvulâ, nonnunquam posticè evanescentibus); margine ventrali convexiusculo, anticè sursum acclinato; dorsali anticè subrecto, leviterque declivi, posticè recto subitoque declivi ; latere postico multum breviore, subcuneiformi ; lineis erectis obliquis aream nymphalem et analem rugantibus ; liganento brevi, prominente; flexurî ventrali costâqne umbonali subobsoletis ; superficie internầ candidâ; dentibus lateralibus, ut in Puniceâ.

Oblong, solid, opaque, rather inequivalve, convex, whitish, glossy, clearly inequilateral, with strong deep concentric sulci, which usually become obsolete in one of the valves, and which diverge and become clevated on passing the flattened space at the upper edge of the more convex valve; ventral edge very slightly convex, curving obliquely upward anteriorly; posterior side much the shorter, subcuneiform; the ligamental edge straight, and abruptly sloping; ligament short and prominent; fold and umbonal ridge almost obsolete; inside pure white, teeth as in Punicea. 
The peculiar elevated sulci on the dorsal areas, at once distinguish it from all the allied species.

Tumbez, Peru.

37. Teluina alternata (pl. lxi. f. 159.) Say, Jour. Ac.Phil. vol. ii. p. 275 ; Amer. Conch. t. 65. f. 1 ; Hanl. Des. Cat. p. 66. sup.t. 14. f. 9.

T. testâ oblongo-elongatâ, solidiusculâ, nitidâ, compressiusculâ, albâ aut albo-flavescente, (intus flavâ) ; concentricè sulcatâ, sulcis remotis, profundis, ad costam umbonalem obsoletissimam alternatim evanescentibus; margine ventrali subreeto; dorsali anticè declivi convexiusculo, posticè recto et multum declivi; latere postico manifestè longiore, ad extremitatem rotundato ; antico cuneiformi ; ligamento prominente; flexurâ inconspicuâ ; dentibus iisdem ut in Puniceâ.

Elongated-oblong, rather solid, and somewhat compressed, of a glossy opaque white or yellowish white, grooved concentrically with rather distant deeply impressed sulci, which alternately disappear in crossing the nearly obsolete umbonal ridge; ventral edge nearly straight; anterior side much the longer, rounded at its extremity, its dorsal edge moderately sloping in a convex line; posterior side cuneiform, its dorsal line being straight and greatly sloping; ligament prominent; fold indistinct; inside white, the teeth as in Punicea.

In the only specimen I have ever seen of this shell, the strix are closer in one valve than in the other. In general appearance the shell is extremely like Striata.

South Carolina. 184.4 .

38. Teluiva rubescens (pl.lx. f. 153.) Hanley, Zool. Proc.

T. testâ T. Striate et Punice simillimâ, ab hâc autem differt, testâ tenuiore anticæ emarginationis experte, ab illâ natibus obtusioribus et extremitate posticâ minus attenuatî ; ab utrâque, superficie nitidissimâ, ligamento infosso, margineque dorsali convexiore et utrinque subæqualiter declivi; sulcis in utrâque valvulâ posticè obsoletis ; dentibus ut in Puniceâ, sed minimis, inconspicuis.

Most closely allied to Striata and Punicea, but differing from the former by the greater obtuseness of its beaks, and the lesser attenuation of its hinder extremity; from the latter by its more delicate texture and the absence of any anterior emargination; from both, in the sunken ligament, the greater convexity and more equal slope of the dorsal edge. The sulci are obsolete posteriorly 
in both the valves, and the whole surface is peculiarly glossy; the tceth are as in Punicea, but very small and indistinct.

Tumbez and Panama (Cuming).

39. Tellina prora (pl. lx. f.152.) Hanley, Zool.Proc.1844.

T. testâ subtrigonâ, ovali, solidâ, convexiusculâ, subæquilaterali, nitidâ, extus intusque pallidè roseâ ; aut sublævigatâ, aut concentricè et tenuissimè striatâ; margine ventrali convexo; dorsali utrinque valdè et subæqualiter declivi, subrecto; extremitate posticâ acuminatâ; flexurâ ventrali costâque umbonali subobsoletis ; ligamento prominulo; dentibus lateralibus magnis, antico approximato.

Subtriangular, oval, tolerably convex, solid, glossy, nearly equilateral, uniform pink both within and without, becoming deeper towards the beaks, most delicately and regularly striated concentrically; ventral edge convex; dorsal edges nearly equally sloping, slopes strong and scarcely at all convex; posterior end acuminated; fold and flexure nearly obsolete; ligament but little prominent, both slopes being slightly excavated; lateral teeth large, the anterior approximate.

Porto St. Elena, and Salango, West Columbia.

40. Tellina laceridens (pl.lxi. f.168 and 176. and pl. lxvi. f. 258.) Hanley, Zool. Proc. 1844.

T. testâ oblongo-subtrigonâ, solidâ, opacâ, subæquilaterali, nitidissimâ, convexinsculâ, albâ (intus candidâ), supernè lævigatâ, infernè concentricè et confertim striatâ ; margine ventrali convexiusculo; dorsali utrinque convexiusculo, et subæqualiter declivi; cxtremitate anticâ rotundatâ (plerumque subattenuatâ), posticâ rotundato-acuminatâ; costâ umbonali et flexurâ ventrali inconspicuis ; ligamento magno, elongato, prominente; dentibus primariis laceratis, antico laterali subapproximato, postico laterali minore, remoto.

Var. Testâ magis trigonâ, undique sulcis confertis excavatâ.

Oblong subtriangular, solid, subequilateral, of an extremely glossy enamel-like opaque white surface, which is smooth near the beaks, and grooved closely towards the but slightly convex ventral margin ; dorsal line nearly equally sloping on each side, the edges very slightly convex ; anterior extremity rounded (and in the typical examples rather attenuated), posterior end obtusely acuminated; fold and umbonal ridge obsolete; ligament large, elongated, and prominent; inside white; the primary teeth minutely jagged, and 
one of them rather large, anterior lateral rather approximate, posterior lateral smaller and distant.

Tumbez, Peru.

Var. More triangular, the close concentric sulci occupying the entire surface. Chiriqui, West Columbia.

Its extraordinary teeth, large and elongated ligament, and either smooth or closely sulcated surface, suffice for its distinguishment.

41. Telutina Madagascariensis (pl. lxiii. f. 218.) Gmelin, 3237; Wood Gen. Concl. 169. t. 39. f. 2, 3; List. 386. f. 233 ; 'T. rosea, Lam. no. 14; Hanl. Des. Cat. p. 63. t.4. f. 46.

T. testâ ovatâ, crassissimâ, convexâ, subimpolitâ, pallidè roseâ, lævigatâ; margine ventrali vix convexiusculo; dorsali utrinque valde declivi; costâ umbonali latâ, obtusâ ; latere antico manifestè breviore, postico subcuneiformi ; extremitate anticâ obtusâ ; superficie internâ roseâ, margine cardinali latissimo; dentibus lateralibus subobsoletis, parvis, antico approximato, postico remoto; impressionibus nuscularibus fortiter impressis.

Ovate, very thick, convex, rather dull, darker or paler pink, smooth, ventral edge but little convex; anterior side somewhat the shorter, its extremity rounded, its slope moderate; posterior side subcuneiform, its extremity obtuse, its dorsal edge much sloping and slightly convex; umbonal ridge very obtuse; ligament prominent; inside rosy, scars deeply impressed; hinge-margin very broad; lateral teeth subobsolete, small, anterior one approximate, posterior distant.

Madagascar.

The figure in Lister is referred to by Spengler for his T. rudis, but neither the locality he gives, nor the expression "with coarse transverse strix," will apply to this species.

42. Telitna Tongana (pl. lxiii. f. 209.) Quoy and Gaimard, $\Lambda$ strolabe Zool. vol. iii. p. 498. t. 81. f. 11, 12, 13 .

T. testâ oblongâ, solidâ, subpellucidâ, subæquivalvi, convexâ, subæquilaterali, nitidâ, sublævigatâ, albâ (intus albidâ), roseo ad nates radiatâ, eodemque colore ad laterum extremitates ornatissimè pictâ; margine ventrali subarcuato, posticè sursum acclivi; dorsali anticè vix declivi, posticè leviter declivi convexo ; latere postico paululum breviore, attenuato, subrostrato; flexurâ ventrali valde conspicuâ ; costâ umbonali prominente; umbonibus tumidis; ligamento infosso; dentibus lateralibus hand maguis, subæquidistantibus.

Oblong, solid, subequivalve, convex, subequilateral, rather pel- 
lucid, nearly smooth, glossy, white, the beaks rayed with rosecolour, the extremities of the sides pink; ventral edge subarcuated, ascending posteriorly; anterior side very slightly the longer, its dorsal edge scarcely sloping; posterior edge attenuated and somewhat beaked, its dorsal side convex and moderately sloping; the flexure and umbonal ridge very conspicuous; umbones tumid; ligament sunken ; inside whitish, a ligamental callus, and rather small and nearly equidistant lateral tecth.

Tonga.

43. Teluina elegans (pl. lxv. f. 241.) Gray in Wood's Ind. Test. sup. t. 1. f. 5 ; Hanl. Des. Cat. p. 62. t. 1. f. 5.

T. testâ oblongo-elongatâ, valdè tortuosâ, subinæquivalvi, subæquilaterali, solidâ, politâ, subventricosâ, lævigatâ; nivcĥ, (intus albidâ) roseo radiatâ, radiis latis versus marginem ventralem arcuatum et posticè acclinatum evanescentibus; margine dorsali anticè convexiusculo et vix declivi, posticè leviter declivi et prope nates roseas subincurvato deinde convexo ; latere postico paululum longiore, attenuato, leviter subrostrato ; extremitate posticâ rotundato-angulatâ; ligamento brevi, pergrandi, prominente; costâ umbonali obsoletissimâ; dentibus parvis, antico subapproximato.

Twisted, elongated-oblong, solid, rather inequivalve, subequilateral, subventricose, smootl, lighly polished, white with broad rosy rays, which disappear towards the arcuated and posteriorly ascending ventral margin ; extremity of the anterior side rounded, its dorsal edge but slightly sloping; posterior side very slightly the longer, attenuated, obtuse at the extremity; umbonal ridge quite obsolete ; ligament peculiarly large, short, and prominent; inside white, the lateral teeth small and rather approximate.

Gulf of Mexico.

- 44. Tellina radiata (pl. lxiii. f. 220, 221.) Lin. Syst. 1117 ; Lam. no. 1 ; Chem. 6. f. 102 ; Wood, Gen. Con. t. 3S. f. 2, 3 ; Ency. Mèt. t. 289. f. 2, 3 ; Hanl.Des.Cat. p.61.t.4. f.26; Knorr. vol. iv. t. 2. f. 2, 4; T. unimaculata, Lam. no. 2.

T. testâ oblongo-elongatî, subinæquilaterali, haud tortuosâ, subventricosâ, solidấ, lævi, politâ, albâ, (intus flavescente) radiis roseis latis plerumque ornatî; margine ventrali vix convexiusculo; dorsali anticè vix declivi, posticè subrecto et leviter declivi; extremitate lateris antici longioris rotundatâ, lateris postici subattenuatâ, obtusè angulatî; ligamento brevi, magno, prominente; costấ umbonali obsoletî̀; flexurî̀ ventrali conspicuâ ; lunulî distinetâ, angusto-lanceolatâ; dentibus lateralibus validis, subæquidistantibus. 
Var. testâ radiorum experte; natibus roseis.

Elongated-oblong, more or less ventricose, solid, not twisted, of a highly polished smooth white, with zones of very pale yellow, and generally with broad rosy rays; ventral margin scarcely convex; anterior side rather the longer, its dorsal edge scarcely sloping, its extremity rounded; posterior side slightly attenuated, its extremity obtusely subangulated, its dorsal edge nearly straight and but slightly sloping; ligament short, large, and prominent; lunule distinct, elongated-lanceolate; inside yellowish ; lateral teeth strong and nearly equidistant.

West Indies.

45. Tellina Brasiliana (pl. Ixii. f. 179.) Spengler, Skriv. Nat. Selskab. Kiobenh. 1798; T. semizonalis, Lam. no. 3; Deles. t. 6. f. 1 ; Hanl. Des. Cat. p. 61. sup. t. 11. f. 60.

T. testâ oblongo-elongatâ, inæquilaterali, solidî, convexiusculâ, nitidâ, pallidè roseo-violaceâ, lævigatâ ; margine ventrali subrecto ; dorsali anticè vix declivi et paululum convexiusculo, posticè declivi et subrecto; latere antico longiore, producto; extremitate posticâ obtusè angulatâ; costâ umbonali obtusâ ; lunulâ lanceolatî angustâ; superficie internâ roseo-purpurascente, radiis duobus pallidioribus aut albis ad extremitatem posticam ornatâ ; dentibus lateralibus remotis, postico parvo.

Elongated-oblong, inequilateral, solid, slightly convex, glossy, pale lilac, smooth; ventral margin nearly straight, slightly ascending in front, its flexure distinct; the umbonal ridge obtuse; anterior side much the longer, its dorsal slope very gentle; posterior extremity obtusely angulated, the dorsal edge nearly straight and moderately sloping; a narrow lanceolate lunule; the inside of a purplish crimson with two pale or white rays at the posterior extrcinity; teeth remote, equidistant, the posterior one small and rather indistinct.

Brazil (fide Spengler).

46. Tellina pudica (pl. lvi. f. 7.) Hanley, Zool. Proc. 1844.

T. testâ parvâ, solidâ, ovato-subtrigonâ, subæquilaterali, nitidâ, candilâ, sublævigatâ, tenuissimè concentricè striatâ ; margine ventrali anticè arcuato, posticè subito sursum acclinato; dorsali utrinque valdè declivi, anticè convexo, posticè elongato et subrecto ; latere antico paululum breviore, subventricoso, rotundato; postico compresso, rostrato; cxtremitate posticâ subacuminatî; natibus prominentibus; flexurầ ventrali costâque umbonali subinconspi- 
cuis; ligamento minimo, infosso ; superficie internâ politâ ; dentibus lateralibus distinctis, subapproxinnatis, subæcuidistantibus.

Small, ovate, subtrigonal, nearly equilateral but rather longer posteriorly, rather ventricose in front but compressed at the posterior end, tolerably thick, of a very glossy pure uniform white, with scarcely impressed concentric strix; the ventral edge bulging out towards the rounder anterior extremity, but rising in rather a concave line towards the posterior end, which is strongly beaked and has the tips rounded but mich attemuted; front dorsal edge convex and strongly sloping, ligamental edge elongated, nearly straight and strongly sloping; beaks prominent; umbonal ridge and fold not conspicuous; ligament sunken and minute; inside polished, the lateral teeth distinct and nearly equally subapproximate.

Catbalonga, Isle of Samar.

47. Teltina Sowerbir (pl. lxiii. f. 205.) Hanley, Zool. Proc. 1544.

T. testâ subellipticâ, subæquivalvi, tenui, compressî, lævigatâ, politâ, candidâ; margine ventrali arcuato, posticè sursum acclinato; dorsali anticè vix paululum declivi, convexiusculo, posticè paululum declivi et prope nates subincurvato, deinde convexo; latere antico longiore, subproducto; postico rotundato-acuminato; ligamento parvo, angustissimo, infosso ; flexurâ ventrali costâque umbonali subinconspicuis; superficie internâ albidâ, plerumque aurantio tinctâ ; dentibus lateralibus tenuibus, subæquidistantibus.

Nearly elliptical, subinequivalve, compressed, lighlly polished, of an uniform smooth white (in some specimens with a tinge of rosy orange which increases in intensity towards the beaks); ventral edge arcuated, and rising at the posterior extremity ; anterior sile decidedly the longer, its extremity rounded, its dorsal edge nearly horizontal; posterior side attenuated, but rounded at its termination, its dorsal edge a little sloping at first, slightly incurved near the beaks, and then decidedly convex; ligament sunken, and very narrow ; inside usually tinged with orange; lateral teeth thin, and nearly equidistant.

Australia.

45. Telliva lata (pl. lxiv. f. 237.) Quoy et Gai. Astrol. 7ool. vol. 3. p. 497. t. S1. f. 8, 9, 10; Lam. 2nd. ed. vol.6. p.108; Hanl. Des. Cat. p. 71. sup. t. 14. f. 13.

T. testâ subovali, inæcquilaterali, solidâ, subæquivalvi, compressiusculâ, nitidâ, albâ, sublævigatâ, rubro eleganter radiatâ; radiis 
interruptis; margine ventrali convexo, ntrinque (maximè autenposticè) sursum acclinato; dorsali posticè valdè declivi prope unbones subincurvato moxque subrecto, anticè convexiusculo et paulo declivi; latere postico brevi, acuminato; antico prodncto, ad cxtremitatem rotundato-obtuso; natibus acutis, rubro-roseis ; ligamento infosso; superfieie internâ albâ aut flavescente; dentibus lateralibus modicis, haud remotis.

Large, suboval, subequivalve, inequilateral, strong, rather compressed, nearly smooth or marked with concentric striulæ; of a glossy white with brilliant rays of a rosy red; ventral edge convex, rising at each extremity, but more particularly so at the posterior end which is short and acuminated; anterior side produced, its extremity obtusely rounded, its dorsal edge but slightly convex and little sloping; posterior dorsal edge greatly sloping, somewhat incurved near the rather acute beaks which are always rosy-red, and then nearly straight or but slightly convex; ligament sunken; inside usually tinged with yellow, lateral teeth moderately large and distant.

South Seas.

49. Tellina chloroleuca (pl. Ixiii. f. 208, 210.) Lam. no. 15 ; Rumphius t. 45 . f. 1.

T. testâ ovatâ, subtenui, convexâ, nitidâ, albidâ aut albido-flavescente, radiis multis angustis pallidè roseis ornatâ, sublævigatâ, (lineis obsoletis radiantibus sæpe versus margincm ventralem strias concentricas confertissimas decussantibus); margine ventrali arcuato, posticè sursum acclivi; dorsali anticè convexo aut convexiusculo satisque declivi, posticè satis brevi convexiusculo et valdè declivi; latere antico longiore, ad extremitatem rotundato; postico brevi, acuminato; natibus roseis, prominulis ; costâ umbonali et flexurâ ventrali conspicuis; ligamento angusto infosso; superficie internâ albido-flavescente; dentibus lateralibus, distinctis, subrquidistantibus.

Var. Radiis albidis et rubro-aurantiis pictâ; natibus vix roscis.

Ovate, convex, rather thin, of a glossy yellowish white, with numerous interrupted narrow rays of a palc rose colour, nearly smooth, (often decussated towards the arcuated and posteriorly rising ventral margin with concentric striulæ and obsolete radiating lines); anterior side the longer, its extremity rounded, its dorsal edge convex and moderately sloping; posterior side acuminated, very slightly beaked and rather short, the dorsal edge but slightly convex and much sloping; beaks of a decp rose-colour and rather prominent; ligament narrow and sunken; unbonal ridge and 
flexure distinet; inside yellowish white; lateral teeth distinct and nearly equidistant.

Var. Rayed with orange-red and white; beaks but slightly if at all rosy.

Isle of Negros, Philippines (Cuming).

- 50. Tellina levigata (pl. lxiv. f.225, 227.) Lin. Sys. 1117 ; Lin. Mus. Ulr. 4S0 ; Schroet. einl. t. 7. f. 10 ; List. t. 387. f. 234; Lam. no. 36 ; Hanl. Des. Cat. p. 68.

T. testâ ovato-rotundatâ, solidâ, subæquilaterali, nitidâ, convexâ, aut subventricosâ, sublævigatâ; margine ventrali anticè arcuato, posticè sursum acclinato; dorsali, anticè subdeclivi magis minusve couvexo, posticè declivi et supernè subretuso aut subrecto et infemè convexo; latere antico paululum longiore, rotundato, dilatato; postico magis minusve angulato; natibus prominentibus; pube striis lamellosis rugosâ; ligamento infosso ; flexurâ costâque umbonali conspicuis; cardine, dentibus lateralibus validis, subapproximatis, subæquidistantibus.

Var. a. Subalbidâ, radiis roseo-aurantüs ornatâ. Var. $b$. (T. conciuna, Plil. Ab. und Bes. Conch. part. 5. t. 5. f. 1.) Albidâ, marginibus intus extusque rubro-aurantiis.

Rounded-ovate, solid, subequilateral, glossy, convex or subventricose, nearly smooth (there are obsolete crowded radiating lines, and frequently but not always minute very close raised concentric striula towards the lower margin and at either extremity); ventral edge arcuated in front, greatly rising behind; anterior side rather the longer, rounded and dilated, its dorsal edge more or less convex and not much sloping; posterior side more or less angulated, its dorsal edge sloping and nearly straight or slightly retuse above, but convex at its termination; beaks prominent; ligament sunken; fold and flexure conspicuous ; lateral teeth strong, subapproximate, subequidistant.

Var. $a$. Whitish, or flesh-coloured with rosy orange rays. Var. b. White with the edges alone of a bright orange red, and the umbones and interior usually tinged with yellow.

An extremely variable species, with the beaks usually worn at the touching point.

St. Thomas, West Indies.

51. Telliva semex (pl. lvi. f. 8,) Hanley, Zool. Proc. 1844.

T. testâ ovali, crassâ, inæquilaterali, subventricosâ, nitidâ, albidâ (intus submargaritacê̂̀), anticè rotundatâ, posticè obtusâ ; concentricè striatâ, striis anticè subimbricatis confertissimisque, posticè 
remotioribus et elevatis ; margine ventrali convexo ; dorsali ntrinquc convexo aut convexiusculo, anticè subdeclivi, posticè declivi; latere antico multo longiore; natibus obtusis ; ligamento minimo, prominulo ; lunulâ angustissimâ; costâ umbonali nullâ, flexurâ subobsoletâ; dentibus lateralibus conspicuis, postico magis approximato.

Var. Ovatâ aut obovatâ, margine dorsali utrinque magis declivi.

Oval, thick, inequilateral, subventricose, glossy, whitish, with concentric striæ, which in front are crowded and subimbricated, but behind are rather distant and elevated ; ventral edge convex ; dorsal edges more or less convex, the hinder one sloping, the front one but moderately so, anterior side much the longer, rounded (and sometimes attenuated) at its extremity ; posterior extremity obtuse ; ligament very small and rather prominent; a very narrow lunule; beaks obtuse; flcxure nearly obsolete; inside subnacreous; lateral tecth distinct, the hinder much the closer.

Var. Ovate or obovate, the dorsal edges more sloping.

Were it not for the slight fold, it might easily be mistaken for a Donax.

52. Telliva bimaculata (pl. lvi. f. 16, 19, 20, 21, 22.) Lin., Sys. 1120 ; Chem. vol. vi. f. 127, 132. Dillwyn. D. Cat. p. 101. Encyc. Méth. t. 290. f. 9, 10. Donovan, Brit. Shells, t. 19. f. 1. Turt. Biv. Brit.t. 8. f. 5 ; Lam. no. 52 ; Hanl. Des. Cat. p. 71. t. 4. f. 83 ; 'T. sexradiata Lam. no. 53.; Hanl. Des. Cat. p. 71. sup. t. 11. f. 37 .

T. testâ ovatâ aut ovato-rotundatâ, crassâ, convexâ, nitidiusculâ, lævigatî, variis coloribus pictâ; margine ventrali convexo aut arcuato (sæpe posticè paululum subincurvato); dorsali utrinque paululum convexiusculo, anticè valde declivi, posticè brevi leviterque declivi; latere antico longiore, attenuato, ad extremitatem rotundato; postico brevi, obtusè biangulato ; costâ umbonali et flexurâ ventrali obsoletis; ligamento brevi, prominente; natibus acutis, nynphis prominentibus, incumbentibus; dentibus primariis permagnis; lateralibus brevibus, crassis, subæquidistantibus, (plerumque obsoletis).

Varying in shape from ovate to rounded ovate; thick, convex, slightly glossy, smooth; ventral edge varying from convex to arcuated, often slightly incurved posteriorly; hinder side much the shorter, obtusely biangulated, its dorsal edge very short and but slightly sloping; anterior side much attenuated, its extremity rounded, its dorsal edge much sloping and little convex, beaks inclined; ligament short but very prominent; primary teeth large, 
the lateral (which however are usually obsolete), short, thick, and nearly equidistant.

The varieties in colouring are too numerous to specify, the principal however, are are as follows ; violet, orange-red, white, yellow or pinkish red, (either uniform, or rayed with purple, the white specimens with usually two lateral crimson internal spots); whitish or yellowish with narrow interrupted violet rays often assuming the appearance of arrow-heads; violet, rayed with white; whitish, with broad fawn-coloured aud narrower purphish rays.

Britain, and West Indies. 1844.

53. Teluina Lucinoides (pl. lvi. f. 32.) Hanley, Zool. Proc.

T. testâ suborbiculari, tenui, subæquilaterali, subventricosâ, impolitâ, intus extusque albâ, striis concentricis tenuissimis lineisque radiantibus minutissimis obsoletè decussatâ, utrinque rotundatâ; margine ventrali arcuato ; dorsali utrinque convexiusculo et subæqualiter declivi ; latere antico paululum longiore; flexurâ costâque umbonali obsoletis; ligamento angustissimo, infosso ; dentibus lateralibus magnis, æquidistantibus.

Suborbicular, thin, subequilateral, rather ventricose, dull, both externally and internally white, with very delicate concentric strix and most minute radiating lineoles; ventral margin strongly arcuated; extremities rounded; dorsal edges nearly equally sloping and slightly convex; anterior side very slightly the longer; umbonal ridge and fold obsolete; ligament very narrow, sunken; lateral teeth distinct, equidistant.

Not unlike the shell which is figured without a name in the 292nd plate (f. 8.) of the Encyclopèdie Mètlodique.

Chain Island, South Seas.

\section{Telurna nux (pl. lvi. f. 33.) Hanley, Zool. Proc. 1844.}

T. testâ obovali, subinæquivalvi, subæquilaterali, tenui, convexâ aut subventricosâ, nitidâ, sublævigatâ aut infernè concentricè substriatâ, intus extusque albidâ, umbonibus hyalinis et fulvis ; margine ventrali subarcuato; dorsali utrinque convexo, satis et aqualiter declivi; extremitate posticâ obtusâ, attenuatâ; ligamento angustissimo, infosso ; natibus obtusis ; flexurâ distinctầ ; eostâ umbonali subinconspicuâ ; dentibus lateralibus distinctis, antico paululum propinquiore.

Oboval, thin, slightly inequivalve, alnost equilateral, from convex to subventricose, rather glossy, whitish both externally and 
internally, with the umbones diaphanous and of a tawny orangecolour; nearly smooth or merely substriated concentrically towards the somewhat arcuated ventral margin ; dorsal edges convex, equally and moderately sloping on either side; beaks obtuse ; fold distinct; umbonal ridge almost obsolete; posterior side obtuse and attenuated; ligament extremely narrow, sunken; lateral teeth distinct, the anterior slightly the nearer.

Cagayan, Misamis, Mindanao; St. Nicolas, Zebu.

More oval than the three succeeding allied species.

55. Telitina Pinguis (pl.lvi. f. 34.) Hanley, Zool. Proc. 1844.

T. testâ parvâ, rotundato-ovali, tenui, subinæquivalvi, subæquilaterali, nitidâ, convexâ aut subventricosâ, intus extusque albidâ (rarius incarnatâ), lævigatâ (nonnunquam concentricè substriatâ); margine ventrali arcuato, dorsali utrinque convexo et subæqualiter declivi; extremitate posticâ obtusâ; flexurâ distinctâ; natibus minimis ; costâ umbonali ferè obsoletâ; ligamento angustissimo, infosso ; dentibus ut in Nuce.

Rounded-oval, thin, rather inequivalve, nearly equilateral, from convex to subventricose, both externally and internally whitish, or more rarely flesh-coloured, smooth, (sometimes concentrically substriated); the ventral edge arcuated; the dorsal on each side nearly equally sloping and convex; beaks minute; fold distinct; umbonal ridge almost obsolete; posterior end obtuse; ligament extremely narrow and sunken; teeth as in $N u x$.

St. Nicolas, Zebu.

By its more orbicular outline it may be distinguished from $N u x$ and Casta. It is still more closely allied to Robusta, but its tenuity, more obtuse hinder extremity, and the greater convexity and less sudden slope of the dorsal edges, suffice for its separation.

\section{Teluina robusta (pl.lvi. f.2, 3.) Hanley,Zool.Proc.1844.}

T. testâ parvâ, rotundato-subtrigonâ, solidâ, subinæquivalvi, subæquilaterali, ventricosâ, nitidâ, aut albo-flavescente, aut pallidè rosaceâ, sublævigatâ (plerumque inferius remotè substriatâ); margine ventrali valdè arcuato, dorsali utrinque subrecto et valdè declivi; latere postico attenuato, ferè subrostrato, ad extremitatem acuminato; ligamento angustissimo, infosso ; natibus distinctis, prominentibus, et rectè incurvatis; umbonibus tumidis; flexurâ listinctâ; costâ umbonali ferè obsoletâ ; lunulâ parvâ; superficie internâ, plerumque sub umbonibus, flavidâ aut roseâ ; dentibus ut in Nuce. 
Rounded-subtrigonal, solid, rather inequivalve, nearly cquilateral, ventricosc, of a glossy yellowish white, or pale rose-colour, nearly smooth, or marked in fresh specimens with distant striula towards the extremely arched ventral margin; dorsal edges nearly straight and strongly sloping on either sidc; posterior side attenuated, almost beaked, and obtusely acuminated at the cxtremity; ligament extremely narrow and sunken; umbones tumid; beaks distinct, prominent, and incurved; fold distinct; umbonal ridge almost obsolete; inside usually yellow or rose-coloured at the umbones; a small lunule; teeth as in Nux.

Isle of Annaa, South Seas, and Isle of Burias, Philippines.

Is elosely allied to Nux, Pinguis and Casta, but of a stouter tcxture even in the youngest individuals. The ligamental edge bcing nearly straight, easily separates it from Pinguis, where it is decidedly convex.

\section{Tellina casta (pl. lvi. f. 9,) Hanley, Zool. Proc. 1844.}

T. testâ obovali, tenuissimâ, subinæquivalvi, subinæquilaterali, pellucidâ, convexâ, nitidâ, extus intusque candidâ, lævigatî ; margine ventrali maximè arcuato ; dorsali utrinque subrecto, subæqualiter satisque declivi; extremitate posticâ angustâ, biangulatâ; ligamento angustissimo, subinfosso; natibus acutis; flcxurâ ventrali costâque umbonali distinctis; dentibus ut in Nuce.

Oboval, extremcly thin, slightly inequivalve, nearly equilateral, convex, glossy, pellucid, white, smooth; ventral margin extremely arcuated; the dorsal on either side nearly straight, moderately and nearly equally sloping; beaks acute; fold and umbonal ridge distinct; posterior extremity narrow and biangulated; ligament extremely narrow and scarcely, if at all, projecting; teeth as in $N u x$.

Singapore.

Bears some resem blance to $N u x$, but the shape is leșs broad, the ventral edge decidedly arcuated, the dorsal edges less convex and shorter, and the umboncs colourless.

58. Tellina balaustina (pl. lvi. f. 10.) Lin. Sys. 1119. Poli. Test. Sic. vol. i. t. 14. f. 17.; Lam. 2nd ed. vol. vi. p. 209 ;" Phil. En. Mol. Sic. vol. i. p. 25 ; Hanl. Des. Cat. p. 72. sup. t. 9. f. 17 ; Lucina balaustina, Payr. Cat. Cors. t. 1. f. $21,22$.

T. testâ obovatâ, aut suborbiculari, solidiusculâ, convexâ, nitidiusculâ, albo-flavescente, radiis angustis rubris ornatâ, sublæevigatâ, nonnunquam lineis elevatis concentricè striat $\hat{\imath}$; margine ventrali arcuato; dorsali utrinque convexo aut convexiusculo, satisque de- 
clivi; latere antico vix paululum longiore, ad extremitatem rotundato ; extremitate posticâ obtusissimè subangulatâ ; natibus acntis, prominentibus, rectè incurvatis ; ligamento angustissimo, infosso ; umbonibus plerumque flavis; flexurâ ventrali costâque umbonali satis conspicuis; superficie internâ flavâ; dentibus lateralibus magnis, subæquidistantibus.

Shape varying from obovate to suborbicular, moderately strong, decidedly convex, when quite perfect dull and covered with raised membranaceous concentric strix, but usually worn smooth and rather glossy; whitish or yellowish, with numerous narrow red rays and the umbones tinged with yellow; ventral edge arcuated; both edges of the dorsal line convex and moderately sloping; front extremity rounded; that of the scarcely shorter posterior side most obtusely subangulated; beaks prominent and incurvated; ligament extremely narrow and sunken; fold and umbonal ridge tolerably manifest; inside yellow; lateral teeth large and nearly equidistant.

Mediterranean.

59. Tellina obliquilineata (pl.lvi.f. 11, and pl.lix. f. 127.) Conrad, Jour. Ac. N. S. Philad. 7.

T. testâ parvâ, ovatâ, tenuiusculâ, inæquilaterali, convexâ, nitidâ, intus extusque flavescente aut rosaceo-incarnatâ, tenuissimè striatâ ; striis obliquis et anticè flexuosis; margine ventrali subarcuato; dorsali anticè arcuato et declivi, posticè longiore convexiusculo et angulum acutum cum margine ventrali formante; latere antico brevi, rotundato; postico producto, acuminato ; natibus ligamento que parvo prominulis; flexurâ costâque umbonali inconspicuis; dentibus lateralibus satis distinctis, subæquidistantibus, antico majore.

Small, ovate, rather thin, very inequilateral, glossy, convex, tinged both externally and internally with yellow or rosy fleshcolour, and most delicately but distinctly striated in oblique lines which become flexuous in front; the ligament small and scarcely projecting; the beaks rather prominent; the umbonal ridge and the fold not conspicuous; anterior side short and rounded, the dorsal slope rather sudden and very convex; posterior side produced, and rendered acuminated by the elongated and rather convex ligamental edge forming an acute angle with the rather arcuated ventral; lateral teeth distinct, neither very distant, the anterior decidedly larger.

Sandwich Isles.

60. Tellina aypulacea (pl. lvi. f. 23, 24.) Philippi, (June 
1844) Ab. und Bes. Conch. part 5. t. 5. f. 7 ; T. puella, Hanley, Zool. Proc. (November) 1844.

T. testâ inæquilaterali, tenui, ventricosâ, lævi, nitidiusculâ, extus intusque albido-roseâ aut pallidè carneâ; margine ventrali anticè arcuato, posticè sursum acclinato; dorsali anticè primum retuso et vix declivi deinde arcuato satisque declivi, posticè primum subrecto deinde convexiusculo et valde declivi ; latere antico longiore, rotundato; postico brevi, et obtusè angulato; flexurâ costâque umbonali haud conspicuis sed satis distinctis; lunulâ parvâ, impressâ; natibus obtusis; ligamento angusto, prominulo; dentibus parvis; lateralibus remotis, subæquidistantibus.

Ovate, thin, inequilateral, ventricose, smooth, rather glossy, pink or flesh-coloured both externally and internally; ventral edge arcuated in front, rising posteriorly; dorsal edge convex and but little sloping in front, slightly convex and much sloping behind; anterior side the longer, rounded; posterior side short, narrowed and angulated; umbonal ridge nearly obsolete, ventral flexure distinct; beaks obtuse; ligament rather prominent; teeth small, the lateral distant and nearly equally remote.

Senegal.

Dr. Philippi's publication had not reached me at the date of my describing this very distinct species.

61. Tellina striatula (pl. lxi. f. 175.) Lam. no. 33 ; Enc. Mèth. t. 292. f. 1 ; T. hippopoidea, Jonas, Ab. und Bes. Conch. part 3. t. 5. f. 1 .

T. testâ sublenticulari, subobliquâ, paululum subinæquivalvi, solidiusculâ, subnitidâ, candidâ, sublævigatâ ; margine ventrali valdè acuto, posticè sursum acclinato; dorsali anticè convexo, satisque declivi, posticè subrecto et valdè declivi; natibus acutis, prominentibus; flexurâ ventrali subinconspicuâ ; areâ posticâ dorsali marginibus acutis costæ umbonalis circumseptâ, planulatî aut subconcavâ; ligamento infosso ; latere antico longiore, rotundato; extremitate posticâ breviter acuminatâ; superficie internâ niveâ ; dentibus lateralibus magnis, antico approximato.

Sublenticular, rather oblique, very slightly inequivalve, not very strong, convex, slightly glossy, white, nearly smooth, (being only marked with most indistinct minute radiating lines near the arcuated ventral margin which rising upward posteriorly almost forms a rectangle with the nearly straight and strongly sloping ligamental edge ; front side the longer, extremity rounded, dorsal edge convex and moderately sloping; beaks acute and prominent, slightly curving 
forwards ; ligament sunken; edges of the almost terminal umbonal ridge acute, the intervening space flattened or concave; fold not conspicuous; inside pure glossy white; lateral teeth large, the anterior approximate.

St. Nicholas, Zebu.

The Inflata of Chemnitz (6. f. S6.) is very like this species, but I do not venture to assert its identity, as the figure certainly differs in some respects, and neither Lamarck nor Philippi, although both conversant with the figure, have quoted it.

62. Tellisa deltomalis (pl. lix. f. 128 and pl.lxiv. f. 229.) Lam. no. 49 ; Hanl. Des. Cat. p. 70. sup. t. 13. f. 3 ; T. lactea, Quoy et Gai. Voy. Astrol. Zool. vol. 3. p. 501.t. S1. f. 14, 15, 16; Deles. t. 6. f. 7.

T. testâ subtrigonâ, ovatâ, obovatâ, aut suborbiculari, solidâ, subinæquivalvi, convexâ, subæquilaterali, impolitâ aut vix nitidiusculâ, intus extusque albidâ, sublævigatâ; margine ventrali in medio subrecto, utrinque sursum acclivi ; dorsali anticè vix declivi, posticè valdè declincute incurvato; latere postico subcuneiformi, ad extremitatem subangulato; extremitate anticâ obtusâ; natibus prominentibus, rectè incurvatis; flexurâ costâque umbonali distinctis; ligamento magno, infosso; dentibus lateralibus parvis, antico approximato, postico remoto plerumque subobsoleto.

Var. Latere antico haud dilatato; margine dorsali anticè magis declivi, posticè recto haudque incurvato.

Shell varying in shape from ovate-triangular to suborbiculartriangular, solid, slightly inequivalve, convex, subequilateral, scarcely if at all glossy and usually quite dull chalky white, nearly smooth or only marked with rather strong lines of growth; ventral margin sloping upward at both ends, nearly straight in the middle; fold and umbonal ridge distinct; beaks prominent and incurved; ligament large but sunken; anterior side dilated, obtuse, dorsal slope slight; posterior side somewhat wedge-shaped (at times almost subrostrated), its dorsal edge incurved and very strongly sloping, its extremity subangulated and much attenuated; lateral teetl small, the anterior approximate, the posterior distant and often almost obsolete.

Var. Ligamental edge not incurved but straight; anterior side not dilated, slope stronger, and extremity rounded.

Australia.

63. Teluina fausta (pl. lxiv. f. 230, 234) Donovan, vol. 3. t. 98 ; Dor. Cat. t. 5. f. 5 ; Dillwyn D. Cat. p. 94; Hanl. Des. Cat. 
p. 68. t.4. f. 68 ; T. lævis, Wool, Gen. Con. p. 181. t. 37. f. 1 ; T. remies, Born, p. 36. t. 2. f. 11 ; Lam. no. 31; List. t. 266. f. 102 .

T. testâ ovato-suborbiculari, solidî, convexâ aut subventricosâ, impolitâ, albidâ ; concentricè striatî, striis tenuibus, confertissimis, ad umbones posticèque obsoletis; lineis verticalibus interruptis fissuræformibus notatî; margine ventrali convexo vel subarcuato; dorsali posticè subrecto (plerumque subincurvato) declivi, anticè prope umbones retuso, deinde convexo, satisque declivi; latere postico breviore, subbiangulato; extremitate anticâ rotundatâ; natibus prominentibus, acutis; ligamento maximo, prominente; flexurâ ventrali satis distinctâ; superficie internâ nitidâ, plerumque flavescente; dentibus lateralibus magnis, antico approximato.

Var. Obovatî, extus flavescente, intus flavâ.

Rounded-ovate, solid, varying from convex to subventricose, dull whitish, with vertical fissure-like interrupted lines, and crowded concentric fine striæ, which latter become obsolete on the umbones and posteriorly; ventral edge varyiug from convex to subarcuated ; beaks prominent and acute, with a forward inclination; fold tolerably distinct; ligament very large, projecting; anterior side rounded, rather the longer, the dorsal edge at first slightly concave and then convex and moderately sloping; posterior end nearly biangulated, the dorsal edge nearly straight (usually incurved) and rather strongly sloping; inside glossy, white, or tinged with yellow; lateral teeth large, anterior approximate.

Var. Obovate, yellowish; within deep yellow.

West Indies.

64. Teluna discus (pl.lxiv. f. 228, 232) Hanley, Zool. Proc. 1844 .

T. testâ T. remiei simillimâ, sed subobliquâ et sulcis concentricis valdè irregularibus vixque continuis; natibus liaud rectè incurvatis; margine dorsali posticè elevatiore, anticè prope nates prominulas subincurvato ; umbonibus lævigatis ; extremitate posticâ angulatâ.

Var. Testâ magis compressâ ; sulcis concentricis haud rudibus, et versus marginem ventralem solum conspicuis.

In sculpture, colour, and general shape extremely like Remies, but appearing oblique from the beaks having a forward inclination, and the anterior dorsal edge being slightly incurved ; posterior dorsal edge the more elevated, longer than in the last species; posterior extremity distinctly angulated; ventral edge slightly ascending posteriorly; beaks rather prominent. 
Var. More depressed, the sulci less coarse and only visible near the ventral margin.

Isle of Ticao, Philippines.

65. Tellina remies (pl. lxiv. f. 226.) Lin. Sys. 1119 ; Lin. Mus. Ulr. p.482 ; Chem. vol.6. f.113; Wood, Gen.Conch. p.182. t. 3S. f. 1 ; Dillw. D. Cat. p. 94; Hanl. Des. Cat. p. 67. sup. t. 1. f. 2 ; T. sulcata, Lam. no. 32 ; T. convexa, Wood, Ind. Test. Sup. t. 1. f. 2.

T. testâ suborbiculari, solidissimâ, inæquivalvi, æquilaterali, ventricosâ, subimpolitâ, extus intusque albidâ, epidermide tenui fulvo-cinereâ aut fulvo-fuscâ indutâ ; supernè concentricè striolatâ, infernè concentricè sulcatâ, sulcis latis, profundis, rudibus ; margine ventrali valdè arcuato; dorsali utrinque subrecto, anticè paululum, posticè satis declivi; latere antico rotundato; postico supernè subangulato; ligamento satis magno, prominente; lunulâ nullâ; natibus obtusis et rectè incurvatis ; flexurâ ventrali conspicuâ; costâ umbonali subobsoletâ ; dentibus magnis, validis, antico laterali quamplurimum approximato, postico permagno subremoto.

Suborbicular, very solid, inequivalve, equilateral, ventricose, scarcely glossy, whitish both within and without (covered when fresh with a dull yellowish brown epidermis), most delicately striated concentrically near the obtuse and incurved beaks, but very coarsely grooved towards the regularly arcuated ventral edge; anterior side rounded, its dorsal edge nearly straight or very slightly convex and but little sloping; posterior side subangulated above, its dorsal edge moderately declining and straight or subretuse; fold obscure, flexure conspicuous; ligament large and prominent; no lunule; teeth large and strong, the front lateral as close as possible, the linder very large and rather distant.

Baclyon, Isle of Bohol (Cuming); Amboyna; Australia. 1844.

66. Tellina cyrenoidea (pl. lvi. f. 31) Hanley, Zool. Proc.

T. testâ suborbiculari, solidiusculà, inæquivalvi, valdè inæquilaterali, subventricosâ, sordidè albâ (intus sub umbonibus purpureâ), concentricè costellatâ; striis minutis obliquè radiantibus costellas confertas posticè decussantibus; margine ventrali arcuato; dorsali utrinque valdè et subrectè declivi, anticè brevi, posticè longiore; latere antico breviore, obtusè rotundato; extremitate losticâ obtusâ, paululum attenuatâ ; natibus prominentibus ; lunulâ distinctâ; ligamento infosso; flexurâ costâque umbonali 
obsoletissimis: dentibus lateralibus parvis, distinctis, subæquidistantibus.

Suborbicular, tolerably solid, inequivalve, very inequilateral, rather ventricose, hardly at all glossy, dirty white, with regular close-set narrow concentric ribs, which posteriorly are decussated by minute rather oblique radiating striulæ; ventral edge arcuated; anterior side the longer, its dorsal edge strongly sloping, rather long, nearly straight, its extremity rounded; posterior end obtusely rounded, slightly subangulated above, by the short straight and much sloping dorsal edge; beaks prominent; fold and umbonal ridge obsolete; ligament sunken ; a purple internal stain beneath the umbones; lateral teeth small, but distinct, subequidistant and rather close.

St. Nicolas, Isle of Zebu.

67. Telliva splendida (pl.lvi. f. 39.) Anton, Verz.Conch. p. 5.

T. testâ suborbiculari, solidiusculâ, subinæquivalvi, inæquilaterali, convexâ, nitidâ, albido-flavescente, prope umbones subcærulescente aut purpureo tinctâ; anticè profundè et concentricè sulcatâ, dein strïs subradiantibus remotis obliquè exaratâ, et in valvâ sinistrâ posticè concentricè striatâ; margine ventrali subarcuato; dorsali utrinque subrectè declivi, anticè brevi; extremitate anticâ obtusè rotundatâ, supernè angulatâ; latere postico longiore, ad extremitatem rotundatam subattenuato; ligamento infosso; costâ umbonali obsoletâ; flexurâ ventrali subinconspicuâ; superficie internâ purpureâ ; dentibus lateralibus parvis, distinctis, subapproximatis, antico magis approximato.

Suborbicular, tolerably strong, rather inequivalve, inequilateral, glossy (usually, as in the succeeding species, coated here and there with a dark rust-like substance), yellowish white assuming a pale blueish or purplish cast towards the beaks ; with strong rather distant concentric anterior grooves, followed by deep and not very close oblique radiating ones, which terminate posteriorly in one valve in fine close concentric striæ; ventral edge rather arcuated; anterior extremity obtusely rounded and rather angulated by the very short straight and much sloping dorsal edge; posterior side the longer, rather attenuated at its rounded extremity, the dorsal slope strong and nearly straight; ligament sunken and small; flexure not conspicuous; umbonal ridge obsolete; inside purple; lateral teeth small but distinct, close, anterior one the more so.

Basay, Isle of Samar; coarse sandy mud, four fathoms ; (Cuming).

65. Tellina Shevegalexsis (pl. lvi. f. 17.) Ilanley, Zool. Proc. 1844. 
T. testâ T. splendida simillimâ, sed striis sulcisque exilioribus et magis confertis; utrâque valvulâ striis arcuatis obliquis ad extremitatem posticam notatâ; superficic internâ purpureâ, albo posticè biradiatâ.

Extremely like the last, but in addition to the superior delicacy and more crowded arrangement of both sulci and striæ, the posterior end is distinguished by the possession of those curved oblique striæ which we perceive less distinctly in Carnaria; the inner surface is adomed posteriorly with two white or pale rays on a purplish ground.

Senegal.

69. Tellina carnaria (pl. lvi. f. 37, 38.) Lin. 1119 ; Chem. vol.6. f. 126 ; Wood, Gen. Conch. t. 40. f. 4; List.t. 339. f.176. Hanl. Des. Cat. p. 72 . t. 4. f. 79 ; Lucina carnaria, Lam. no. 8 ; Strigilla camaria, Turt. Brit. Biv. p. 117. t. 7. f. 15.

T. testâ suborbiculari, convexâ, subinæquivalvi, inæquilaterali, solidiusculâ, nitidâ, albido-roseâ, (intus roseâ), variè et exiliter striatâ, striis medio obliquis, radiantibus, ad latus posticum spectantibus; anticè flexuosis et cum striis mediis angulum formantibus; posticè tenuissimis, confertissimis, arcuatis (nonnunquam subobsoletis, et cum striis mediis angulum acutissimum formantibus); margine ventrali subarcuato; dorsali utrinque subrecto, declivi, anticè brevi, posticè elongato ; extremitate anticâ obtusâ, supernè subangulatâ ; latere postico valdè longiore, attenuato, ad extremitatem rotundato; flexurâ costâque umbonali obsoletis ; dentibus lateralibus distinctis, subæquidistantibus.

Suborbicular, convex, moderately strong, glossy, pink, rose-coloured, or whitish more or less tinged with pink, most delicately striated in various directions; striæ on the anterior area very flexuous and forming an angle with those on the central area, which obliquely radiate posteriorward; strix on the posterior slope extremely fine, curved, and meeting at a very acute angle; ventral edge arcuated; anterior side much the shorter, its extremity obtuse, and subangulated above, its dorsal edge short and moderately sloping, posterior extremity rounded and narrowed, the dorsal edge greatly sloping and nearly straight; a small lunule; ligament sunken; umbonal ridge and flexure nearly obsolete; beaks incurved; inside rosy; lateral teeth distinct and nearly equidistant.

W. Indies; W. Columbia.

The shell is deeper from the umbones to the ventral margin, than in Splendida; the posterior and central strix are often divided by a smooth radiating space. 

1814.

70. Teldina sincera (pl. 1.x. f. 144.) Hanley, Zool. Proc.

'T. testî T. Carnarice simillimâ, sed majore, latiore, compressâ et albillâ; striis tenuioribus; ligamento valdè angusto; natibus paululum ad latus anticum spectantibus; margine ventrali solum subarcuato; dentibus lateralibus conspicuis, subæquidistantibus.

Extremely like Carnaria, but larger, broader, white and depressed; the ligament extremely narrow ; sculjsture still finer, beaks slightly curved forward, ventral edge less arcuated; lateral teetl conspicuous and subequidistant.

N. W. Coast of America, (Dr. Sinclair).

r 71. Tellina pisiformis (pl. lvi. f. 30.) Lin. Syst. 1120.; Dillwyn. D. Cat. p. 102.; Wood. Gen. Con. p. 194.

T. testâ parvâ,suborbiculari, solidiusculâ, ventricosâ, nitidiusculâ, albido-roseâ; obliquè substriatâ, striis posticè angulo acuto reflexis; margine ventrali convexo; dorsali anticè brevi subrecto et paululum declivi, posticè convexo et valdè declivi; extremitate anticâ obtusâ ; latere postico longiore, rotundato ; natibus prominentibus; umbonibus extus intusque roseis; flexurî costâque umbonali obsoletis; dentibus lateralibus distinctis, subæquidistantibus.

Var. Testâ majore, pallidè luteî.

Small, subglobose, tolerably strong, but slightly glossy, botlı within and without of a pinkish white with the umbones rosy, obliquely substriated, the strix curving posteriorwards, except over the umbonal slope, (which, as well as the fold, is quite obsolete) where they are met at acute angles by another set with a slight anterior inclination; ventral edge simply convex; front dorsal edge very short, nearly straight, and scarcely sloping, the hinder one convex, and greatly sloping; anterior extremity obtuse; posterior side the longer and narrower, tip rounded; beaks very prominent; lateral teeth distinct, and nearly equidistant.

Var. Larger, and of an uniform pale yellow.

W. Indies.

The Cardium discors of Montagu, which has erroneously been inserted in the British Fauna, is evidently this or the succeeding species.

72. Tellina flexuos (pl. lvi. f. 28, 29.) Say. Journ. Ac. N.S.; Philad. vol. ii. p. 303. ; Hanl. Des. Cat. p. 2; T. mirabilis, Philippi, Wiegm. Archiv. f. nat. 1841. p. 260. 
T. testâ T. pisiformi simillimâ, pallidiore autem et margine ventrali magis arcuato; strïs obliquis, fortioribus, flexuosis, posticè bis terve in ziczac flexis; ligamento minimo,

Extremely like T'. pisiformis, but paler and more arcuated at the ventral margin; the oblique strix are flexuous and more deeply impressed than in that species, and at the posterior extremity several times change their direction at acute angles, thus forming numerous zigzag lines; the ligament is minute and not prominent.

United States.

73. Tellisa finbriata (pl.lx. f. 132.) Hanley, Zool. Proc. 1844.

T. testî obovato-suborbiculari, solidî, convexâ, impolitâ, intus extusque candidâ, strïs concentricis confertissimis lamellosis fimbriatis et lineis radiantibus confertis decussatâ; margine ventrali arcuato, posticè sursum acclinato ; dorsali utrinque convexiusculo, anticè subdeclivi, posticè valdè declivi ; latere antico longiore, rotundato ; extremitate posticâ brevi, angulatâ ; costâ umbonali valdè conspicuâ; ligamento infosso; lunulâ distinctâ; dentibus lateralibus subremotis, subæquidistantibus.

Rounded-obovate, solid, convex, very inequilateral, dull white, with extremely delicate crowded lamellar striæ, which are fringed by the intersection of radiating lines; one of the valves projecting beyond the other at the beaks ; ventral margin arcuated and rising posteriorly ; anterior side the longer and rounded, its dorsal edge moderately convex and sloping; posterior side short and angulated, the ligamental edge strongly sloping and tolerably convex; fold very prominent; ligament sunken; a distant lanceolate lunule; inside white; lateral teetl rather remote and subequidistant.

Mus. Cuming.

74. Tellina decussata (pl. lx. f. 184.) Jam., no. 45. ; Hanl. Des. Cat. p. 70. ; Encyc. Mèth. t. 292. f. 2.?

T. testâ suborbiculari, subrequilaterali, solidâ, convexâ aut subventricosâ, impolitâ, sordidè albâ, striis concentricis costellas radiantes decussantibus; strïs elevatis, confertissimis, tenuissimis; costellis numerosis, paululum obsoletis; margine ventrali arcuato; dorsali utrinque declivi, anticè convexo, posticè convexiusculo ; latere antico rotundato ; postico obtusè angulato ; ligamento iufosso; natibus prominulis; flexurâ costâque umbonali inconspicuis ; dentibus lateralibus magnis, antico propinquiore.

Var. Testâ majore, candidâ; striis magis elevatis et minus conertis ; margine dorsali postico elevatiore. 
Suborbicular, solid, nearly equilateral, from convex to subventricose, dull dirty white, sculptured with numerous somewhat obsolete radiating costellæ, which are decussated by very fine raised crowded conecutric strix; ventral cdge arcuated ; the dorsal sloping from the rather prominent beaks on either side, and rather the more convex in front ; anterior side rounded, posterior obtusely subangulated; ligament sunken, fold and umbonal ridge not conspicuous; inside white; lateral teeth large, the front one the nearer.

Var. Larger, white; the linder (and not as in the type,) the front), dorsal edge the more elevated; the striæ more elevated and rather morc distant.

Australia; the variety from Ceylon.

75. Teluina carnicolor, (pl.lvi. f.15.); T. incarnata Hanley, Zool. Proc. 1844.

T. testâ oboratî, subobliquâ, inæquilaterali, ventricosâ, solidâ, incarnatâ aut albido-rosê̂, impolitî; striis elevatis concentricis tcnuissimis strias radiantes elevatas confertissimè dccussantibus; margine ventrali arcuato, posticè sursum accliviore ; dorsali anticè declivi et prope nates paululum incurvato, posticè elevatiore subarcuato et subito declivi ; latero antico longiore, rotundato; extremitate posticâ rotundato-angulatâ ; ligamento angusto, parvo, infosso ; natibus acutis, prominentibus ; flexurâ costâque umbonali subobsoletis; lunulâ lanceolatâ; superficie internâ flavescente, margines versus subroseâ ; dentibus lateralibus maximis, subæquidistantibus.

Obovate, rather oblique, dull, solid, ventricose, pinkish white, or flesh-coloured, closely decussated by elevated radiating, and by fine concentric lamellar strix ; ventral edge arcuated, and ascending posteriorly; anterior side the longer, its extremity rounded and slightly attenmated, its dorsal edge sloping, and near the acute and promineut beaks, somewhat incurved; hinder extremity subangulated, the more elevated ligamental edge sloping rather suddenly, and in an arcuated line ; ligament small, narrow, and sunken ; umbonal ridge aud fold nearly obsolete; a lanceolate lunule; inside yellowish, pink near the margins; lateral teeth very large and nearly equidistant.

San Nicolas, Zebu.

In almost every adult specimen the tips of the beaks are chalky white, the umbones yellow, and the ligamental edge rosy.

I had inadvertently designated this shell with a pre-occupied name.

76. Teluiva gakgada (pl. lxi. f. 156 and pl. lxï. f. 181,) 
Lim. Sys. 1116 ; Lin. Mus. Ulr. 476. Chemn. vol. vi. f. 63, 64; Lam. no. 40 ; Hanl. Des. Cat. p. 69. t. 3. f. 1.

'T. testâ ovatâ, solidâ, compressiusculâ, nitidiusculâ, candidâ; margine ventrali arcuato; dorsali anticè subrecto ct valdè declivi, posticè elevatiore valdè declivi paululum convexiusculo dentato; latere antico longiore, angustato, rotundato; extremitate posticâ, obtusè biangulatâ ; lunulâ areâque ligamentali excavatis ; natibus acutis, prominentibus, ligamento infosso ; dentibus lateralibus validis, æequidistantibus.

Var. a. Sulcis irregularibus, rudioribus, subobliquis, concentricis, posticè exaratâ ; lineis subobliquis, exilibus, concentricis, anticè striatâ. Var. b. Sculpturâ obsoletissimâ.

Ovate, solid, rather compressed, and not very glossy, uniform white; ventral edge arcuated; anterior side the longer, attenuated but rounded at its extremity; its dorsal slope sudden, and nearly straight; hinder side obtusely subangulated, its dorsal edge toothed, rather short and scarcely convex, the slope sudden; ligament sunken ; lunule and lozenge excavated ; beaks acute and prominent ; fold and umbonal ridge by no means conspicuous; inside white, or yellowish white; the lateral teetl strong and subequidistant.

Var. a. Hinder side roughened by coarse irregular rather oblique concentric grooves; anterior surface traversed by more or less delicate rather oblicuely concentric stria. Var. Z. Sculpture almost cntirely obsolete, but usually discernible on one of the areas.

Siquijor, Philippines, (Cuming), \&c. 1844.

77. Tellina spinosa (pl. lviil. f. 40.) Manley, Zool. Proc.

T. testî ovatâ, solidiusculâ, subimpolitâ, inæquilaterali, convexiusculâ, extus intusque albidâ, striis minutis elevatis confertissimis concentricè asperatâ ; margine ventrali arcuato, posticè sursum acclinato, dorsali posticè elevatiore convexo et declivi, antice prope nates acutas subincurvato, deinde subrecto subdeclivi; latere postico brevi; extremitate anticâ rotundatâ ; extremitate posticâ spinarum duabus vel tribus seriebus radiantibus serratâ ; lunulâ parvâ distinctâ ; ligamento infosso ; dente laterali antico subapproximato, postico remoto.

Ovate, moderately strong, inequilateral, not very convex, dull whitish, with minute elevated crowded concentric stria; ventral edge rather arcuated, and rising behind; anterior' side the longer, its extremity roumded, its dorsal edge slightly incurved near the 
acute beaks and then straightish, (or slightly convex), and moderately sloping; posterior side short, and armed at its extremity with two or three rows of radiating serrated spines, its dorsal edge conrex and sloping; ligament sunken ; a small distinct lunule; inside white, the anterior lateral tooth slightly the closer, postcrior distant.

Island of Ticao.

78. Telitina crassa (pl. lxi. f. 169, 173.) Pennant, Brit. Zool. vol. iv. p. 73. t. 48. f. 28 ; Wood Gen. Conc. p. 186. t. 4.0. f. 1 ; Turt. Biv. Brit. p. 109. t. 7 f. 2 ; Lam. no. 35; Hanl. Des. Cat. p. 68. t. 4. f. 75 ; List. t. 299. f. 136 ; T. rigida Don. Br. Slı. vol. 3. t. 103.

T. testâ rotundato-ovali, subobliquâ, solidâ, inæquivalvi, subventricosî, impolitî, albidâ, radiis angustis rubris plerumque ornatî, sulcis rudibus concentricè exaratî ; margine ventrali arcuato ; dorsali utrinque declivi, convexo, posticè elevatiore, anticè convexiore ; latere antico longiore, rotundato, prominente ; postico abbreviato, ad extremitatem obtuso; costâ umbonali obsoletâ ; natibus incumbentibus ; lunulâ parvâ, excavatâ ; ligamento infosso ; flexurâ distinctâ; superficie internâ plerumque aurantiâ, (rarius albidâ); dentibus lateralibus magnis, antico subapproximato; cicatricibus muscularibus profundè impressis.

Roundish oval, slightly oblique, inequivalve, very inequilateral, rather ventricose, dull white, almost always adorned with narrow red rays, and concentrically and coarsely grooved; the ventral edge arcuated; the anterior side the longer, its dorsal edge arcuaterl, its extremity rounded and projecting; the posterior side rather short, its dorsal slope very sudden and very convex, its tips most obtusely subangulated; the umbonal ridge obsolete; ligament sunken; fold distinet; the beaks recurved anteriorwards; the lunule small and excavated; inside usnally stained with orange, very rarely white; the lateral teeth large, the anterior one rather approximate; muscular impressions deeply impressed.

Britain ; Europe.

The T. maculata of Turton (Biv. Brit.) is a young discoloured specimen of this species.

79. Telliva plectrum (pl. lxi. f. 177.) Hanley, Zool. Proc. $1 S 45$.

T. testâ obovatâ, solidâ, convexiusculâ, subæquilatcrali, impolitâ, intus cxtusque albidî, lamellis confertis concentricis undique asperatâ ; interstitiis lavibus ; margine ventrali arcuato ; dorsali utrinque subrecto, subdeclivi (in junioribus declivi); extrenitate anticâ 
rotundatî; latere postico vix paululum longiore, biangulato; natibus acutis; costâ umbonali prominulâ; ligamento infosso (?); lunulâ distinctî; dente laterali antico majore postico parvo et remotiore.

Obovate, solid, moderately convex, nearly equilateral, not polisher, white, the entire surface covered with regular, distinct, short and crowded lamellæ, the interstices smooth; ventral edge arcnated; anterior side very slightly the shorter, extremity rounded; posterior extremity biangulated; dorsal edges straightish, and not greatly sloping; beaks acute; ligament sunken (?); fold not prominent; a distinct lunule; iuside white, the front lateral tooth distinct, the hinder small and remote.

A single valve in the collectiou of .J E. Gray, Esq. is all I have ever seen of this distinctly characterized species, I am consequently unable to state whether it be equivalve or not.

80. Tellina scobinata (pl. lx 1 . f. 235.) Lin. Syst. 1119 ; Lin. Mus. Ulr. 482 ; Chem. vol.6. f. 122-124; Wood, Gen.Conch. p. 150. t. 35. f. 1; Lam. no 34; Hanl. Des. Cat. p. 68. t. 4. f. 67.

T. testâ suborbiculari, inæquivalvi, solidâ, æquilaterali, ventricosâ aut subventricosâ, impolitâ, albidâ, maculis brunneis undatis radiatâ aut nebulosâ, tuberculis, squamosis confertis undique asperatâ; margine ventrali arcuato; dorsali utrinque subdeclivi et leviter convexiusculo; extremitate anticâ rotundatâ, posticâ obtusè subangulatâ; costâ umbonali distinctâ, obtusâ; lumulî excavatâ, lanceolatâ; flexurâ ventrali conspicuâ; ligamento depresso; disco interno albido-flavescente ; dentibus lateralibus validissimis, subæquiclistantibus.

Suborbicular, solid, inequivalve, equilateral, more or less ventricose, dull whitish clouded or rayed with wavy brown markings, and rough with small crowded rasp-like tubercles which become almost spinous beyond the distinct but obtuse umbonal ridge; fold conspicuons; ligament depressed; a lanceolate excavated lunule; anterior side rounded, the dorsal edge scarcely couvex and little sloping; hinder side with the extremity obtusely subangulated, the dorsal edge nearly straight and moderately sloping; inside yellowish white; the lateral teeth very strong and subequidistant.

Society Islands and Philippines; (Cuming).

- 82́. Tellina lingua-felis (pl. lxiv. f. 236.) Tin. Sys. 1116 ; Lim. Mus. Ulr. p. 476 ; Knorr, vol.2. t.2.f.1; Wood, Gen. Conch. t. 40. f. 2, 3; Lam. no. 37 ; Hanl. Des. Cat. p. 69. t. 3. f. 2.

T. testâ obovatâ, subventricosâ, solidâ, subæquilatcrali, albidâ, 
roseo radiatî, impolitî, squamis tubercularibus confertis undique asperrimâ; margine ventrali posticè arcuato, anticè sursum acclivi; dorsali anticè convexiusculo et paululum declivi, posticè elevatiore convexo et valde declivi; latere postico breviore, subrostrato; extremitate anticâ rotundatâ; natibus acutis, roscis ant roseo-purpureis, incumbentibus ; lunulâ excavatâ, lanccolatâ ; costâ umbonali ct flexurâ conspicuis; ligamento infosso ; dentibus lateralibus validis, subæquidistantibus.

Obovate, rather ventricose, crowded with rasp-like scales, solicl, white with crimson rays and the beaks of the same colour; anterior side rather the longer, its extremity rounded, its dorsal edge slightly convex and little sloping; hinder side slightly beaked, the ligmental edge the more elevated convex and deeply sloping; ventral edge much arcuated in front, ascending posteriorly; tlexuosity and umbonal ridge conspicuous; beaks acute, inclined forwards; lunule deeply impressed, lanceolate; lateral teeth strong, subequidistant.

Isle of Negros, Philippines; (Cuming).

82. Teluixa rugosa (pl. lxiv. f. 233, 238.) Born, p. 29. t. 2. f. 3, 4; Wood, Gen. Conch. t.41. f.2,3; Lam. no.38; Hanl. Des. Cat. p. 69. t. 3. f. S.

T. testî obovatâ, inæquivalvi, subæquilaterali, solidâ, subventricosâ, intus extusque albâ (rarius roseo-purpurascente aut aurantiâ); subconcentricè rugosî, rugis erectis flexuosis interruptis, striis radiantibus minutissimis decussantibus; margine ventrali anticè arcuato; dorsali anticè paululum declivi, posticè subrecto et valdè declivi; latere postico obtusè subcuneiformi; lunulâ elongatâ, excavatâ; flexurâ costâque umbonali conspicuis; dentibus lateralibus magnis, subæquidistantibus.

Obovate, subequilateral, inequivalve, solid, rather ventricose, white both within and without (rarely orange or purplish crimson), with raised interrupted irregularly but concentrically disposed wavy wrinkles which become still rougher from the minute radiating strix; anterior side rounded, its dorsal edge scarcely sloping; posterior side obtusely subcineiform; ligamental edge strongly sloping and nearly straight; ventral edge much arcuated in front; lunule very elongated, excavated; fold and flexure conspicuous; lateral teetl large, subequidistant.

Isle of Opara (Cuming), New Califormia.

83. Tellixi subtruncata (pl. lvii. f. 4.9.) Hanley, Zool. Proc. 1St4. 
T. testâ obovatâ, solidiusculâ, convexâ, impolitâ, valdè inæquilaterali, intus extnsque striis lamellosis confertissimis fimbriatis ornatî; margine ventrali anticè arcuato, posticè subrecto et sursum acclinato; dorsali utrinque magis minusve convexo, anticè declivi, posticè maximè declivi; extremitate anticâ rotundatâ; latere postico brevissimo, subtruncato, angulato ; ligamento infosso ; natibus prominentibus; costâ umbonali subinconspicuâ, terminali ; dentibus lateralibus subæquidistantibus.

Obovate, moderately thick, convex, very inæquilateral, dull whitish, with very crowded fringed lamellar striæ; ventral margin arcuated in front, straightish and ascending behind; dorsal edges moderately convex; anterior side the longer, rounded, its dorsal edge sloping; posterior side subtruncated, its extremity angulated; beaks prominent; fold terminal and not prominent; ligament sunken; inside white, sometimes with two orange rays; lateral teeth subequidistant.

Isle of Bohol, Philippines.

S4. Teluiva pristis (pl. lxi. f. 160.) Lam. no. 4I ; Han. Des. Cat. p. 69. sup. t. 9. f. 4. (young); Enc. Mèth. t. 2S7. f. 1.

T. testâ rotundato-ovatâ, crassâ, subinæquilaterali, convexâ aut subventricosâ, extus intusque albâ, impolitâ; concentricè striatâ, striis elevatis, confertis; interstitiis, striulis minimis radiantibus, decussatis; margine ventrali magis minusve convexo; dorsali anticè brevi, subretuso et paulo declivi, posticè subrecto et valdè declivi; latere antico paululum longiore, ad extremitatem rotundato-obtuso ; latere postico angulato; natibus acutis; lunulâ ligamentoque infosso magnis ; flexurâ costâque umbonali satis conspicuis; dentibus lateralibus subremotis, subæquidistantibus.

Rounded-ovate, thick, rather inequilateral, convex or subventricose, white both within and without, not glossy, with concentric elevated crowded strixe decussated by minute interstitial radiating striulæ; ventral edge more or less convex; dorsal short subretuse and but little sloping in front, nearly straight and considerably sloping behind; anterior side very slightly the longer, obtusely rounded at its termination; posterior side angulated; beaks acute; ligament sunken, and as well as the lunule, large; fold and flexure tolerably strong; lateral teeth rather and nearly equally distant. Australia, \&c.

S5. Tellina Capsoides (pl. lxii. f. 185.) Lam. no. 44; Hanl. Des. Cat. p. 70.

T. testâ obovato-subtrigonâ, solidâ, subæquilaterali, convexius- 
culâ, vix nitidâ, intus extusque albâ aut albidâ ; concentricè striatâ, striis posticè elevatioribus, anticè a lineis radiantibus distinctis decussatis; margine ventrali subarcuato; dorsali utrinque valdè declivi, anticè convexo, posticè recto aut subrceto ; extremitate anticâ rotundatâ; latere postico angulato; flexmrî costâque umbonali satis distinctis; ligamento magno, infosso; dentibus lateralibus distinctis, remotis, validis, subæcuidistantibus.

Obovate-snbtriangular, solid, subequilateral, moderately convex, scarcely glossy, white or whitish, anteriorly decussated by closely radiating and concentric strix, posteriorly with the concentric strix more distant and more elevated; ventral enlge subarcuated; dorsal slopes strong, the posterior nearly straight and roughened by the edges of the concentric sulei; posterior tip angulated; beaks acute; anterior extremity rounded; lignment sunken, and large; fold and flexure moderate; inside white; lateral teeth strong, subequidistant.

Jimaimalan, Isle of Negrros, \&e.; (Cuming).

S6. Teldixa perplexa (pl. 1x. f. 139.) Hanley, Zool. Proc. 1844; T. concinna, (?) Ab. und Bes. Coneh. part 5. t. 5 . f. 1.

T. testâ $T$. ostracece affinis, ovatâ autem, strïsque ejus concentricis confertioribus, et supernè hand lamellosis; margine dorsali antico paululum declivi.

Very like T. ostracea but subovate and not triangular; the concentric strix more crowded and not lamellar, except near the less arcuated ventral margin; the anterior dorsal edge but little sloping.

Bay of Manila and Isle of Amma; (Cuming).

87. Tellina ostracea (pl. lvii. f. 45.) Lam. no. 54; Hanl. Des. Cat. p. 71. sup. t. 14. f. 11 ; Enc. Mèth. t. 290. f. 13.

T. testâ obovato-subtrigonâ, solidiuseulâ, satis convexâ, extus intusque albidâ, lineis elevatis subremotis concentricè ornatî ; interstitiis lævibus; margine ventrali subarenato; dorsali utrinque declivi, anticè eonvexo, posticè recto aut subretıso; extremitate anticâ rotumdatâ ; latere postico paulo breviore euneiformi ; natibus acutis, prominentibus; ligamento infosso; costâ umbonali prominente; dentibus lateralibus, distinctis, postico subremoto.

Obovate-subtriangular, tolerably strong and convex, nniform white, with regular raised rather distant concentric striæ, the interstices smooth; ventral edge arcuated, sloping upward posteriorly; anterior side rather the longer, its dorsal edge convex and sloping, its extremity rounded; posterior side snbrostrated and wedge- 
shaped, its dorsal edge straight (or subretuse) and much sloping; beaks prominent, acute; ligament sunken; umbonal ridge very distinct; inside white; lateral tceth distinct, the linder slightly the more distant.

Ceylon.

88. Telitina plicata (pl. lxii. f. 191.) Falenciennes, Enc. Mèth. t. 287. f. 3.

T. testâ obovali, tenuiusculâ, subventricosâ, tortuosâ, æquilaterali, impolitâ, intus extusque candidâ, striis elevatis lamellosis concentricè ornatî; margine ventrali arcuato, posticè sursum acclinato; dorsali utrinque paululum declivi, anticè convexo (sed juxta lunulam brevem distinctam incurvato), posticè convexiusculo et elevatiore; extremitate anticâ rotundatâ, obtusè biangulatâ; costâ umbonali subcarinatî flexurâque ventrali consp̧icuis; ligamento longo, infosso; dentibus lateralibus parvis, antico subapproximato.

Oboval, rather thin, somewhat ventricose, tortuous, nearly equilateral, dull white, with regular raised and moderately distant concentric sublamellar strix; the ventral margin arcuated, and rising belind; anterior side very slightly the longer, its extremity rounded, its dorsal edge near the short but distinct lunule incurved and scarcely sloping; extremity of the posterior side obtusely binngulated, its dorsal slope the more elevated slightly convex and moderately sloping; ligament elongated and sunken; umbonal ridge subcarinated, and as well as the ventral fold, very distinct; inside white; lateral teeth small, the anterior the more approximate.

Hab.? Mus. Cuming, Metcalfe.

- 89. Tellina crystaldiva (pl. lvii. f. 43.) Chem. vol. 11. p. 210. f. 1947, 1948; Hanl. Des. Cat. p.66. t.3.f. 10 ; Wood, Gen. Conch. p. 149.

T. testâ obovatâ, tenui, inæquivalvi, inæquilaterali, convexiusculâ, nitidâ, submargaritacê̂, candidâ, subpellucidâ, lamellis subremotis concentricis undique ornatî; interstitiis lævibus; margine ventrali valdè arcuato, posticè brevi et incurvato; latere antico longiore, rotundato; postico brevi, rostrato; natibus acutis; ligamento minimo, infosso ; costâ umbonali distinctâ ; dentibus lateralibus distinctis, subæquidistantibus.

Obovate, thin, inequivalve, inequilateral, moderately convex, glossy, pure white, subnacreous, with distant regular raised concentric strix, the interstices quite smooth; ventral edge greatly 
arcuated; anterior side much the longer, rather dilated, rounded, its dorsal edge convex and not greatly sloping; posterior side terminating in a short beak, which is placed very high up owing to the shortness and small slope of the incurved dorsal edge; fold promineut ; ligament minute and sunken; beaks acute; inside wlite; lateral teeth distinct, subequidistant.

St. Elena, West Columbia. W.

90. Tellina Bunveri (pl.lviii. f. 99.) Broderip and Sowerby, Zool. Jour. vol. 4. p. 362. t. 9. f. 2 ; Hanl. Des. Cat. p. 72 . t. 13. f. 51 .

T. testâ trigonâ, suborbiculari, subtenui, subæquilaterali, inæquivalvi, compressâ, candidâ, submargaritaceâ; valvulâ planulatâ lineis elevatis concentricè striatâ; valvulâ convexiore sulcis dilatatis concentricis obsoletissimè anticè et supernè ornatâ ; margine ventrali arcuato; dorsali utrinque valde declivi et dentato, anticè valdè incurvato, posticè subrecto; natibus acutissimis, anticè incumbentibus; ligamento minimo lunulâque maximâ infossis; flexurâ distinctâ; dentibus lateralibus distinctis, subæquidistantibus.

Triangular, rather thin, inequivalve, subequilateral, compressed, subnacreous, white; the convex valve with obsolete distant dilated concentric grooves, which are most visible in front and towards the elevated acute and curving beaks (one of which projects over the other); the flat valve with elevated fine rather irregular and close concentric striæ, which become obsolete posteriorly; ventral edge arcuated; dorsal edges strongly sloping on either side, and armed with large tooth-like projections, the front one greatly incurved, the hinder nearly straight ; ligament minute; dorsal slopes excavated; fold and flexure distinct; lateral teeth distinct, rather remote, and subequidistant.

Salango, WT. Columbia.

91. Telliva lyra (pl. Lxii. f. 187.) Hanley, Zool. Proc. 1844.

T. testâ ellipticî, tenui, compressâ, nitidiusculâ, intus extusque albâ, striis concentricis elevatis ornatâ; striis anticè et infernè confertioribus, interstitïs lævigatis; margine ventrali medio convexiuseulo, utrinque arcuato; dorsali posticè elevatiore convexo satisque declivi, anticè prope lnnulam excaratam, aut horizontali aut leviter acclivi; latere antico paululum longiore, rotundato; extremitate posticâ obtusî; ligamento infosso; natibus acutis, prominentibus, incumbentibus; flexurî obsolctî́; dentibus lateralibus distiuctis, antico approximato, postico parvo, remotiore. 
Elliptic, thin, depressed, scarcely glossy, white both within and without (sometimes subnacreous), witl regular elevated concentric striæ, which are distant towards the very prominent and acute beaks, but become closer towards the ventral cdge (which is rounded at both extremities, but is little convex in the middle); the interstices of the strix quite smooth; anterior side very slightly the longer, the extremity rounded; situation of the umbonal ridge indicated by a linear carina almost adjacent to the convex and moderately sloping dorsal edge and separated from it by a narrow concavity; the beaks curved forwarls; the anterior dorsal edge the less elevated, and at first rumning almost horizontally or even slightly ascending; lunule and nymphal area excavated; front lateral tooth distinct and subapproximate, the hinder one small and distant.

Probably inequivalve, but as yet I liave only seen one of the valves.

Tumbez, Peru.

92. Teluiva Gouldir (pl. lvi. f. 26.) Hanley.

T'. testâ parvâ, obliquè subovatâ, solidâ, convexiusculâ, nitidissimâ, extus intusque niveâ, lærigatâ, valdè inæquilaterali ; margine ventrali anticè fortiter arcuato, posticè sursum acclinato; dorsali antico subdeclivi, prope nates acutas retuso, deinde arcuato; dorsali postico subrecto, subitoque declivi; latere postico brevissimo, obtusè angulato; extremitate anticâ rotundatâ ; lunulâ parvâ; flexurâ costâque umbonali subobsoletis ; ligamento minimo infosso; dente laterali antico parvo et haud approximato, postico rudimentali.

Obliquely suborate, solid, small, moderately convex, very glossy, quite smooth and both within and without of a pure white; ventral margiu much arcuated in front, ascending posteriorly; front dorsal edge moderately sloping, retuse near the acute beaks and then arcuated or convex; hinder dorsal edge nearly straight and suddenly sloping; sides very unequal, the hinder peculiarly short and obtusely angulated; front extremity rounded; fold and flexure almost obsolete; ligament minute and sunken; a small lunule; front lateral tooth small and not approximate, hinder almost rudimentary.

West Indies; (Guilding).

Named in honour of the talented author of the 'Report on the Invertebrata of Massachusets'.

- 93. Teluina hubicunda (pl. lxri. f. 255.) Gould, Proc. Boston Nat. Hist. Soc. $18+5$. 
T. testâ oblongo-ovali, inæquivalvi, compressâ, tenui, subnitidâ, inæquilaterali, pallidè aurantio-rosê̂, radiis subroseis ornatâ; sublævigatâ, concentricè exiliter striolatâ, valvulâ autem alterâ sulcis remotis concentricis posticè exaratâ; margine ventrali medio subrecto; dorsali anticè convexiusculo paululumque declivi, posticè subrecto et subdeclivi; latere postico brevi, angulato ; extremitate anticî rotundato-obtusâ; ligamento prominulo; costâ umbonali subinconspicılâ; dentibus lateralibus distinctis, subæquidistantibus.

Oblong-oval, inequivalve, compressed, thin, not very glossy, inequilateral, of a very delicate salmon-colour, with light pink rays; smoothish, being merely striolated concentrically, with a posterior space grooved concentrically and distantly in one of the valves only; ventral edge straightish in the middle; dorsal slightly convex and very little sloping in front, moderately sloping and nearly straight behind; posterior side short and angulated; anterior extremity obtusely rounded; ligament moderately projecting; fold by no means conspicnous; lateral teeth distinct, and tolerably equidistant.

* With a single anterior lateral tooth.

Africa, (Dr. Bates).

\section{Teluina Mars (pl. lxii. f. 1S0.) Hanley.}

T. testâ oblongâ, solidâ, subæequilaterali, compressiusculâ, extus intusque roseâ, concentricè et confertissimè striatâ, lineisque obsoletis radiatim impressâ; margine ventrali in medio subrecto, utrinque convexo, posticè incurvato; dorsali anticè convexiusculo et vix paululım declivi, posticè prope nates obtusas excavato deinde convexo et subdeclivi; extremitate anticâ rotundatâ; latere postico obtusè acuminato, subrostrato; flexurâ costâque umbonali valdè conspicuis; ligamento infosso; dente laterali quamplurimum approximato.

Oblong, solid, nearly equilateral, rather compressed, rose-coloured within and without, decussated by very crowded concentric strix and obsolete radiating lines; ventral edge nearly straight in the middle, convex at the sides, incurved posteriorly; dorsal edge but slightly convex and scarcely at all sloping in front, posteriorly excavated near the obtuse beaks and then convex and moderately sloping; front extremity rounded; posterior side subrostrated and obtusely acuminated ; fold and flexure very conspicuous ; ligament sunken; lateral tooth as approximate as possible.

The only specimen I have ever seen, (now in the possession of Mr. Cuming,) is stated to have come from Guinea. 
95. Teluiva foliacea (pl. lxiv. f. 253.) Lin. Sys. 1117; Lin. Mus. Ulr. p. 479 ; Chem. vol. 6. f.95 ; Wood, Gen. Conch. t. 36. f. 1 ; Lam. no. 12 ; Haul. Des. Cat. p. 62. t.3. f. 20 ; Knorr.vol.v. t. 29. f. 2 .

T. testâ oblongâ, tenui, planulatâ, nitidissimâ, subæquilaterali, aurantiâ, sublævigatâ, concentricè et obsoletè substriatâ, et supra carinam umbonalem alterâ in valvulâ punctis squamosis radiatâ; margine ventrali subrecto; latere antico subattennato, rotundato; postico biangulato; margine ligamentali convexo, paululum declivi, et spinis lanceolatis armato; umbonibus valdê compressis; natibus inconspicuis ; ligamento infosso; dente laterali approximato, parvo.

Oblong, thin, and flattened, very glossy, subequilateral, bright orange-yellow, nearly smooth but substriated in front with very fine concentric lines, and roughened in one valve beyond the subcarinated umbonal ridge by radiating rows of scaly dots ; ventral edge nearly straight ; anterior side rounded, and rather attenuated; posterior side obtusely biangulated; ligamental edge convex, but little sloping, elongated, and armed with lanceolate spines; ligament elongated and sunken; beaks not prominent; umbones much flattened, plicated; inside somewhat tinged with purple; lateral tooth small and approximate.

San Nicolas, Zebu (Cuming); Amboyna; Moluccas.

96. Tellina magra (pl. kiv. f. 239, and pl. liiii. f. 201. young.) Spengler, loc. cit. (1798); T. acuta, Wood, Gen. Conch. p. 157. t. 44. f. 1; Dillw.Des. Cat. p. 81 ; Hanl. Des. Cat. p. 63. t. 3. f. 25 ; T. elliptica, Lam. no. 16.

T. testî oblongâ, solidâ, inæquilaterali, compressâ, nitidissimâ, lævigatâ, albidâ, pallidè aurantio supernè radiatâ (in junioribus aurantiâ, radiis angustis pallidioribus ornatâ); margine ventrali convexo, posticè sursum acclinato; dorsali anticè convexo et paululum declivi, posticè supernè subretuso satisque declivi; latere antico longiore, rotundato; postico angustato, angulato; natibus roseis, comp̣ressis ; ligamento infosso ; flexurâ costâque umbonali satis conspicuis; dente laterali subapproximato.

Oblong, solid, inequilateral, compressed, smooth and polished, white with pale orange rays near the umbones; the beaks compressed and rosy (in the young the surface is deep orange with narrow paler rays); ventral edge convex and rising posteriorly; anterior side the longer, rounded at the extremity, its dorsal edge more or less convex and but little sloping; posterior side narrow and angu- 
lated, its dorsal edge (in the adult) retuse above and moderately sloping; ligament sunken; fold and flexure distinet; interior whitish tinged with orange; lateral tooth tolerably close.

West Indies; (Wood).

97. Teluina Sol (pl. lxiv. f. 240.) Hanley, Zool. Proc. 1844.

T. testâ oblongo-ellipticâ, solidiusculâ, compressâ, nitidâ, rubroaurantiâ, alterî valvulâ concentricè substriatâ, alterâ sublævigatâ; margine ventrali convexo, posticè sursum acclinato; dorsali utrinque subdeclivi, convexiusculo; latere antico longiore, ad extremitatem rotundato ; extremitate posticâ in junioribus subacuminatâ, in adultis obtusè angulatâ; natibus planulatis; ligamento infosso; dente laterali distincto.

Oblong-elliptic, tolerably strong, compressed, glossy, orange red (rayed in some specimens with paler streaks); one valve with concentric striulx, the other nearly smooth; ventral edge simply convex, ascending posteriorly; dorsal edges moderately sloping, and slightly convex ; anterior side the longer, its extremity rounded; hinder extremity somewhat acuminated in the young, obtusely angulated in the adult; beaks flattened and devoid of colour; ligament sunken; lateral tooth distinct.

Hab.?

The adult is in the cabinet of Mr. Cuming, the young in that of Mr. Metcalfe.

- 95. Teluna strigosa (pl. lxiii. f. 211.) Gmelin, 3239; Dillw. Des. Cat. 82 ; Lam. no. 19 ; Hanl. Des. Cat. p. 63. t. 4. f. 61 ; Le Vagal, Adanson, Seneg. t. 17. f. 19.

T. testâ ovato-oblongâ, solidâ, maquivalvi, convexiusculâ, nitidâ, candidâ, subpellucidî, sublævigatî; margine ventrali subrecto, medio paululum subretuso, posticè sursum acclinato; dorsali anticè arcuato declivi et elevatiore, posticè prope nates subretuso et vix declivi, deinde convexiúseulo et obliquo ; latere postico longiore, ad extremitatem attenuatam subrostrato; extremitate anticî rotunclatâ; flexurâ costâque umbonali satis conspicuis; ligamento infosso; superficie internâ candidâ, plerumque roseo subradiatim tinctâ ; dente laterali approximato, plerumque obsoleto.

Ovate-oblong, solid, inequivalve, moderately convex, of a glossy subpellucid white, with the marks of growth tinged with zones of violet grey, nearly smooth, but the convex valve posteriorly grooved near the beaks with most delicate but distinct crowded strix; ventral margin somewhat retuse in the middle, rising behind; anterior side rather the shorter, its extremity rounded, its dorsal edge 
arcuated; hinder extremity attenuated and subrostrated; fold and flexure distinct ; the ligamental edge at first incurved, and then oblique and slightly convex; within often stained with rose colour; ligament sunken; the approximate lateral tooth almost or entirely obsolete.

Senegal.

99. Telina planata (pl. Ixi. f. 174.) Lin. Sys. 1117 ; Born, t. 2. f. 9 ; Lam. no. 20 ; Philip. En. Mol. Sic. vol.1. p.26; Hanl. Des. Cat. p. 63. t. 3. f. 24 ; Poli. vol. 1. t. 14. f. 1 to 5.

VAR. (?) T. flarescens operculata, Chem. vol. 6. f. 98.

T. testâ ovali, solidiusculâ, inæquivalvi, æquilaterali, convexiusculâ, nitidâ extus intusque albido-carneâ, sublævigatâ; margine ventrali convexiusculo, medio subrecto; dorsali anticè convexiusculo paululumque declivi, posticè subdeclivi et prope ligamentum infossum subretuso ; latere antico rotundato; postico subangulato; flexurâ costâque umbonali satis conspicuis; dente laterali parvo, approximato.

Oval, tolerably strong, inequivalve, equilateral, moderately convex, nearly smooth, pale flesh colour; ventral margin moderately convex, but nearly straight in the middle; anterior side rounded, its dorsal edge convex and scarcely at all sloping ; posterior extremity subangulated; the ligamental margin moderately sloping, retuse near the sunken ligament; fold and flexure tolerably distinct; inside flesh-coloured; lateral tooth small, approximate.

Mediterranean.

The shell represented by Chemnitz (vol. vi. f. 98) is probably a variety. It is slightly more elongated, with the radiating lines more distinct. 1844.

100. Tellina imbellis (pl. lx. f. 155.) Hanley, Zool. Proc.

T. testâ oblongo-ovali, solidâ, inæquivalvi, inæquilaterali, convexâ, nitidâ, extus intusque albidâ, valvulâ convexiore strïs elevatis concentricis posticè notatâ; valvulâ alterâ lævigatâ; margine ventrali convexo, posticè sursum acclinato ; dorsali anticè convexinsculo paululumque declivi, posticè magis minusve declivi et subretuso; latere antico producto, rotundato; postico brevi, obtusè angulato; flexurâ costâque umbonali obsoletis; ligamento prominente ; dente laterali parvo, approximato.

Oblong-oval, solid, inequivalve, inequilateral, convex, rather glossy, whitish (inside white), smooth, excepting upon the posterior side of the more convex valve, which is finely striated by raised 
concentric lines; ventral margin convex and rising behind ; anterior side produced, its dorsal edge tolerably convex and but little sloping; posterior side short and obtusely angulated; ligamental edge straightish or subretuse, more or less sloping; ligament prominent; fold and flexure obsolete; lateral tooth small, approximate.

Hab.?

The unique specimen which I purchased without a locality, is now in the possession of $\mathrm{H}$. Cuming, Esq.

101. Teluina mera (pl. lxvi. f. 268.) Say, Amer. Conch. pl. 64. f. 2 .

T. testâ ovato-suborbiculari, inæquilaterali, convexâ aut convexiusculâ, vix nitidâ, haud solidâ, extus intusque albâ, lineis exilibus elevatis concentricè asperatâ; margine ventrali convexo et posticè sursum subacclinato; dorsali utrinque declivi, anticè convexo, posticè subrecto; latere postico breviore, et inferne obtusissimè angulato ; extremitate anticû rotundatâ ; natibus acutis ; ligamento subinfosso ; flexurâ costâque umbonali haud conspicuis ; dente laterali haud magno, haud approximato.

Rounded ovate, moderately inequilateral, more or less convex, not solid nor highly polished, white both within and without, most delicately striated by raised concentric lines, (which however are scarcely visible in the young); ventral margin convex, and somewhat rising posteriorly; dorsal edges sloping, the front one more or less straight, the linder decidedly convex; posterior side the shorter, very obtusely angulated below ; anterior side rounded; beaks acute; ligament ratlıer sunken ; fold and flexure just evident; lateral tooth neither large nor approximate.

Guayaquil ; soutl coast of U. States.

102. Tellixa cycladiforyis (pl. lvii. f. 61.) Hanley, Zool. Proc. 1844.

T. testâ rotundato-subtrigonâ, temui, ventricosî, intus extusque incarnatâ aut pallidè roseâ, sublævigatâ, aut concentricè tenuissimè striolatâ ; margine ventrali convexo; dorsali utrinque declivi, eonvexiusculo; latere antico rotundato, paulo breviore; extremitate posticâ obtusè subangulatî ; ligamento prominulo ; flexurâ costâque umbonali obsoletis; dente laterali parvo, approximato.

Small, subtriangularly orbieular, thin, ventricose, nearly smooth, (or marked with most minute concentric strix), both within and without of a pale rose or flesh-colour; ventral edge convex, both dorsal edges sloping and moderately curved; anterior side rather the shorter, rounded; hinder extremity obtusely subangnlated; 
ligament tolerably large, and somewhat prominent; fold and flexure obsolete; lateral tooth small, approximate.

San Nicolas, Zebur.

103. Telinina Listeri (pl. lxv. f. 251.) Hanley, Zool. Proc. 1844; Lister, Hist. Conc. t. 288. f. 235 ; T. scutra Gould, Proc. Boston Nat. H. Soc.

T. testâ obovatâ, solidâ, ventricosâ, (anticè subventricosâ), æquilaterali, glabrâ, extus intusque candidâ; margine ventrali medio subrecto ; dorsali anticè arcuato paululumque declivi, posticè recto et declivi; latere antico dilatato, obtusè rotundato ; posticè obtusissimè biangulato; ligamento magno, infosso; natibus obtusis; umbonibus plerumque subplanulatis; flexurâ costâque umbonali satis distinctis; dente laterali parvo subapproximato.

Obovate, solid, more or less ventricose, equilateral, white both externally and internally, almost smooth, (being merely marked with the concentric wrinkles of growth), rather glossy; the ventral edge nearly straight in the middle; the anterior side dilated, its extremity obtusely rounded, its dorsal edge scarcely sloping and much arcuated; hinder extremity most obtusely biangulated, the dorsal edge straight and much sloping; umbonal ridge and ventral flexure not very conspicuous; ligament large and sunken; umbones rather flattened; beaks obtuse; lateral tooth small, and nearly approximate.

Senegal. 1844.

104. Teluina indequalis (pl.lvii. f.44.) Hanley, Zool. Proc.

T. testâ subovatâ, valdè inæquilaterali, solidâ, convexâ, candidâ, tenuiter striatâ; striis supernè obliquis, infernè concentricis, flexuosis; supra costam umbonalem inconspicuam, rugis erectis flexuosis asperatâ; margine ventrali convexissimo; dorsali anticè subincurvato et valdè declivi, posticè brevi recto subdeclivi; latere antico producto, ad extremitatem attenuato, rotundato; extremitate posticâ obtusâ ; natibus acutis ; lunulâ distinctâ ; superficie internâ candidâ, aut flavescente; dente laterali magno, subremoto.

Subovate, very inequilateral, solid, convex, white with fine striæ, which are oblique near the acute beaks, but become concentric and flexuous towards the very convex ventral margin; the surface beyond the umbonal ridge (which is not prominent), covered with elevated flexuous oblique wrinkles, which project so as to form three radiating lines; anterior side produced, attenuated but rounded at the extremity, its dorsal line rather concave and greatly 
sloping; linder side very short, its extremity obtuse but slightly angulated above, its dorsal edge moderately sloping; beaks acute; a distinct lunule; inside yellowish; lateral tooth moderately distant.

Ceylon. 1844.

105. Teluina pumila (pl. lvii. f. 41.) Ilanley, Zool. Proc.

T. testâ T. Philippinurum simillimâ, sed angustiore; margine ventrali medio subrecto; dorsali utrinque recto aut subconcavo, anticè paululum declivi; margine antico recto, verticali; latere postico cuneiformi.

Bearing a very close resemblance to $T$. Philippinarum, but decidedly narrower; both dorsal edges (except in the young) straight or even concave, and the front one which is longer and less sloping than in the next species, forming an angle with the straight and direct anterior margin; the hinder extremity wedge-shaped, the ventral margin (which is nearly straight in the middle) not being elevated posteriorly.

Valparaiso.

106. Tellina Philippinarum (pl. Ivii. f. 55, 56.) Hanley, Zool. Proc. 1844.

T. testâ ovatâ aut subovatâ, tenui, subæquilaterali, intus extusque candidâ, (sæpe umbones versus incarnatầ aut pallidè aurantiâ), submargaritaceâ, concentricè et tenuissimè striatâ; margine ventrali arcuato, posticè sursum acclivi; dorsali anticè brevi recto subdeclivi, posticè declivi et convexiuscnlo; extremitate anticâ obtusâ; latere postico subcuneiformi, aut obsoletè subangulato; ligamento prominulo; concavitate dorsali auticâ lunulam simulante; dente laterali subapproximato, (in junioribus subobsoleto).

Ovate or suborate, thin, subequilateral, rather depressed, whitish (with a pearly gloss), often tinged near the beaks with fleshcolour or pale orange, most delicately striated concentrically ; ventral edge arcuated, inclining upward towards the posterior side, which varies from subcuneiform to obsoletely subangulated; anterior side very slightly the longer, its dorsal edge slightly sloping and not convex, its extremity obtuse; an obsolete lunule; a distinct subapproximate lateral tooth which is nearly obsolete in the young.

Plilippincs. 1844.

107. Teluina culter (pl. lvii. f. 51.) Itanley, Zool. Proc. 
T. testâ parvâ, ovatâ, inæquilaterali, tenuiusculâ, conrexâ, nitidâ, intus extusque aurantio-roseâ, lævigatâ; margine ventrali anticè arcuato, posticè sursum acclivi; dorsali anticè magis minusve convexo satisque declivi; latere antico producto, ad extremitatem obtusè rotundato; postico acuminato; natibus acutis; ligamento vix prominulo; costâ umbonali ferè et flexurâ ventrali omnino obsoletis; dente laterali parvo, approximato.

Small, ovate, inequilateral, thimnish, tolerably convex, both externally and internally of a rosy-orange, nearly smooth, in young specimens there are indications of concentric striæ near the arcuated front of the ventral edge, which latter ascending posteriorly in nearly a straight line, acuminates the short anterior side at its junction with the straight and much sloping ligamental margin; front dorsal edge always convex and not greatly sloping, extremity obtusely rounded; ligament scarcely prominent; ventral flexure entirely obsolete, umbonal ridge nearly so; beaks acute; lateral tooth small, approximate.

Mindanao, Philippines.

108. Teluina Corbuloides (pl. lvii. f. 50, 57.) Hanley, Zool. Proc. 1844.

T. testâ subovali, inæquivalvi, solidâ, subventricosâ, sublævigatâ, roseo-incarnatâ, epidermide tenuissimâ et opali coloribus nitente indutâ; margine ventrali sinistræ valvulæ ultra marginem convexiusculum alterius prominente; margine dorsali anticè convexiusculo et declivi, posticè subrecto et valdè declivi; latere antico breviore, obtusè acuminato; extremitate posticâ rotundatâ; ligamento prominulo; areâ dorsali posticâ in adultis planulatâ; natibus obtusis ; flexurâ ventrali distinctâ ; superficie internâ plerumque aurantio-rubrâ ; dente laterali parvo, approximato.

Var. Z. Oblongâ; margine ventrali subrecto; flexurâ obsoletâ. Var. c. Extus intusque candidâ.

Suboval, inequivalve, solid, nearly smooth, more or less ventricose, covered when fresh with a very thin opalescent epidermis, under which the shell is dull, and of a rosy flesh colour; ventral edge moderately convex and in the left valve projecting beyond that of the right; anterior side shorter, and obtusely acuminated, its dorsal edge nearly or quite straight and much sloping; hinder side rounded, its dorsal edge convex and moderately sloping; hinder dorsal area flattened in the adult; beaks obtuse; ventral flexure distinct; inside usually orange-red; a single small approximate lateral tooth. 
Var. b. Oblong, the ventral edge nearly straight; flexure obsolete. Var. $c$. Entirely wlite.

Catbalonga, Philippines, and Bay of Manila (var. ४.).

109. Teluixa Rhodora (pl.lix. f. 105.) Hinds, Zool. Sulphur, vol. 2. t. 21. f. 3. p. 67.

T. testâ oblongo-triangulari, solidâ, convexâ aut subventricosâ, subæquilaterali, nitidissimâ, lævi, extus intusque albido-roseâ, marginibus roseis; margine ventrali convexiusculo, et anticè convexo; dorsali utrinque subrecto, anticè subdeclivi; latere postico breviore, cuneiformi ; extremitate anticâ obtusè rotundatâ ; flexurâ subobsoletâ; ligamento depresso; dentibus primariis parvis ; laterali antico maximo et subapproximato, postico rudimentali et subremoto.

Oblong-triangular, solid, rather ventricose, nearly equilateral, perfectly smooth and glossy, within and without of a pale pink, becoming rose-coloured near the margins; ventral edge convex in front, dorsal edges nearly straight, the anterior one scarcely sloping; hinder side the shorter, wedge-shaped; front extremity obtusely roumded; ligament depressed; primary teeth small, front lateral close and very large, a rudimentary remote hinder oue.

Straits of Macassar. 1844

110. Telliva felix (pl. Iviii. f. 52.) Hanley, Zool. Proc.

T. testâ subovali, solidiusculâ, valdè inæquilaterali, convexiusculâ, nitilâ, intus extusque roseâ, lævigatâ ; margine ventrali vix convexiusculo; dorsali anticè vix declivi convexo, posticè valdè declivi; latere postico brevissimo, obtusè subtruncato, inferuè obtusè angulato; extremitate anticâ rotundatâ ; costâ umbonali ct flexurâ ventrali subobsoletis; ligamento brevi, prominulo; dente laterali magno, approximato.

Suboval, tolerably strong, very inequilateral, slightly convex, both within and without of a glossy rose-colour, quite smooth; the ventral edge nearly straight; the anterior side produced aud rounded, its dorsal edge convex and little sloping; hinder side extremely sliort, and obtusely but rather obliquely subtruncated; umbonal ridge and fold, nearly obsolete; ligament rather prominent; a single large approximate lateral tooth.

Panama. 1844.

111. Teldisa hilaris (pl. lvii. f. 54.) Hanley, Zool. Proc. 
T. testâ oblongo-cuneiformi, tenui, compressiusculâ, inæquilaterali, nitidâ, lævi, intus extusque roseâ, albo biradiatâ; radiìs latis submediis ; margine ventrali convexiusculo (flexurâ obsoletâ); dorsali anticè vix convexiusculo et subdeclivi, posticè subrecto et valdè declivi ; extremitate lateris antici longioris rotundatâ ; extremitate posticâ brevi, cuneiformi ; dente laterali parvo, subapproximato.

Oblong-wedge-shaped, thin, rather compressed, inequilateral, glossy, smooth, rosy both within and without, with an anterior and posterior subcentral broad white ray; ventral margin slightly convex and devoid of flexure; anterior side the longer, its extremity rounded, its dorsal edge scarcely convex and little sloping; hinder extremity short and wedge-shaped, the ligamental edge nearly straight; the lateral tooth small and nearly approximate.

Red Sea (M. Clery.)

112. Teluina Hiberna (pl. lvii. f. 53.) Hanley, Zool. Proc. 1844.

T. testâ oblongâ, solidâ, compressiusculâ, valdè inæquilaterali, subnitidâ, extus intusque candidâ, lævigatâ ; margine ventrali subrecto; dorsali anticè convexiusculo et paululum declivi, posticè primùm convexo deinde subincurvato ; latere antico producto rotundato ; postico brevi, cuneiformi ; flexurâ subobsoletâ ; ligamento prominulo ; dente laterali, magno, approximato.

Oblong, solid, rather compressed, very inequilateral, rather glossy, white both within and without, smooth; ventral edge straightish; front dorsal margin slightly convex and scarcely sloping, hinder one first convex and then somewhat incurved; anterior side produced and rounded; posterior short and wedge-shaped; flexure nearly obsolete; ligament rather prominent; lateral tooth large, approximate.

Panama; Bay of Guayaquil.

113. Tellina polita (pl. Ivii. f. 60.) Say. Jour. Ac. N. S. Philad. 2. p. 276. ; Say. Amer. Conch. t. 65. f.2. ; Hanl. Des. Cat p. 65. Sup. t. 9. f. 39 .

T. testâ T. Tenerce affini, minus autem inæquilaterali ; extremitate posticâ acutâ, cuneiformi ; margine ligamentali, recto.

Allied to T. Tenera, but less inequilateral, the ligamental edge straight, and the hinder extremity acute and wedge-shaped.

Massachusets to Georgia, North America.

114. Teluina tenera (pl. lvii. f. 59.) Say. Jour. Ac. N. Sc. Philad. 2.p. 303.; Hanl. Des. Cat. p. 65. sup. t. 9. f. 38.; Gould Invert. Massa. f. 44. p. 68. 
T. testâ oblongo-ovali, tenui, inæquilaterali, compressiusculâ, nitidâ, intus extusque candidâ, submargaritaceâ, sublævigatâ; margine ventrali convexiusculo; dorsali anticè subrecto paululumque declivi, posticè declivi et vix convexiusculo ; latere antico producto, rotundato; extremitate posticâ obtusè cunciformi ; flexurâ obsoletâ; ligamento prominulo; dente laterali distincto, approximato.

Oblong-oval, thin, inequilateral, rather compressed, and both within and without of a nacreous white, nearly smooth or with delicate and almost obsolete concentric striæ; ventral edge moderately couvex; dorsal straightish and but little sloping in front, slightly convex and decidedly sloping behind; anterior side produced and rounded; posterior extremity very obtusely wedgeshaped; flexure obsolete ; ligament slightly prominent; lateral tooth distinct and approximate.

North America.

- 115. Tellina incarnata (pl. Ix. f. 142. pl. lxvi. f. 265.) Lin. Syst. 1118; (from his collection); Poli. 1. t. 15. f. 1.; T depressa Lam. no. 22.; Wood Gen. Con. t. 45. f. 3 ; Plilip. En. Moll. Sic. 1. p. 27 ; Hanl. Des. Cat. p. 63. t. 4. f. 48; Turt. Biv. Brit. p. 105. t. 8. f. 6 ; T. squalida Mont. Test. Brit. p. 56.

T. testâ oblongo-ovali, subtenui aut solidiusculâ, subcompressâ, subæquilaterali, subnitidâ, albido-aurantiâ and roseo-aurantiâ, concentricè substriatâ, striis alterâ in valvulâ obsoletis ; margine ventrali convexo ; dorsali anticè convexiusculo paululumque (in junioribus vix minimè) declivi, posticè subrecto aut subretuso et subdeclivi ; latere antico longiore, rotundato ; extremitate anticâ angulatâ subrostratâ ; flexurâ satis distinctâ ; ligamento infosso ; coloribus superficiei internæ plerumque saturatioribus; dente laterali subapproximato.

Oblong-oval, rather thin or but moderately strong, somewhat compressed, subequilateral, more or less glossy, of a pale orange or deep flesh colour, with (in the young chiefly,) two whitish approximate posterior rays, concentrically substriated in one of the valves; ventral edge convex; anterior side rounded and rather the longer its dorsal edge slightly convex and but little sloping; posterior extremity angulated and subrostrated; the ligamental edge straightish or subretuse and moderately sloping; ligament sunken ; fold and flexure tolerably distinct; internal colouring usually darker; lateral tooth subapproximate.

Britain, and Mediterranean. $181 \%$.

116. Tellixa Valtonis (pl. lvii. f. 68.) Hanley, Zool. Proc. 
T. testâ subovali, tenui, compressâ, subæquilaterali, nitidâ, albido-roseâ radio angusto pallidiore (nonnunquam duobus) posticè ornatâ, sublævigatâ, pellucidâ, anticè rotundatâ; margine ventrali convexiusculo; dorsali utrinque convexiusculo, posticè declivi, anticè subdeclivi; latere postico paululum breviore, obtusè cuneiformi ; flexurâ costâque umbonali obsoletis; ligamento prominulo; dente laterali parvo, approximato.

Suboval, thin, compressed, subequilateral, pink with one or two narrow posterior whitish rays, nearly smooth, glossy, pellucid, rounded in front, rather shorter and obtusely wedge-shaped belind; ventral and dorsal edges tolerably convex, very moderately sloping in front, but more so behind ; fold and flexure quite obsolete; ligament moderately prominent; lateral tooth small, approximate.

Hab.? Mus. Metcalfe.

117. Teluina exilis (pl.hix. f.104.) Lam. no. 26 ; Deshayes, Ency. Mèth. vol. iii. p. 1013; Hanl. Des. Cat. p. 64. sup. t. 13. f. 2 ; Deles. t. 6 . f. 6 .

T. testâ subovali, tenuissimâ, compressâ, nitidâ, inæquilaterali, pellucidâ, roseâ, radio uno vel altero posticè ornatâ, minutissimè striatâ; striis anticè concentricis, medio obliquis ; margine ventrali subrecto; dorsali anticè convexiusculo et subdeclivi, posticè subrecto et declivi; latere postico cuneiformi et paulo breviore; extremitate anticâ rotundatâ ; flexurâ costâque umbonali obsoletis; ligamento prominulo; dente laterali parvo, subapproximato.

Suboval, very thin, pellucid, compressed, rosc-coloured, with two narrow white posterior rays, nearly smooth being only marked with very delicate and almost imperceptible regular striæ, which, concentric in front, become oblique on reaching the middle of the shell; ventral margin nearly straight; anterior side rather the longer, rounded, its dorsal edge not much sloping and slightly convex; posterior end wedge-shaped, the ligamental edge nearly straight; fold and flexure obsolete; ligament moderately prominent; lateral tooth small, approximate.

Hab.? Mus. Walton. 1844.

118. Tellina virgo (pl. lvii. f. 42.) Hanley, Zool. Proc.

T. testâ subovali, teunissimâ, compressiusculâ, inæquilaterali, nitidâ, pellucidâ, candidâ, striis obliquis subremotis regularibus ornatâ; margine ventrali subrecto; dorsali anticè convexo et subdeclivi, posticè subrecto ct declivi; latere antico longiore, 
rotundato ; extremitate posticû obtusè cumeifor'ni ; flexurâ costâque umbonali subobsoletis; ligamento satis prominente; dente laterali listincto, subipproximato.

Suboval, ineguilateral, rather compressed, very thin, pellucid, white, with regular and not very close oblique strix ; rentral edge nearly straight; dorsal margin more or less ronvex and not greatly sloping in front, nearly straight and moderately sloping behind; anterior side the longer, rounded; posterior extremity obtusely wedge-shaped; ligament morlerately prominent; fold and flexurn obsolete; lateral tooth distinct, subapproximate.

Chiriqui, West Columbia.

119. Teluina stmuls (pl. lvii. f. 65.) Soverby, Brit. Miscel. 1). 75 ; Mont. Test. Brit. Sup. p. 167 ; Turt. Biv. Brit. p. 102; Philip. Ab. und Bes. Conch. part 9. pl. 5. f. 7.

'T. testâ subovali, solidiusculâ, inæquilaterali, convexâ, nitidâ, extus intusque albidî, concentricè et oblique striatî; striis obliquis, minutis, confertissimis; ultimî parte posticî alterâ in valvulâ sublævigatâ, in alterâ autem striis subimbricatis laudque confertis concentricè exarntî; margine ventrali subrecto; dorsali anticè convexiusculo, posticè brevi subretıso, utrinque paululum dcclivi; latere antico longiore, rotundato; extremitate posticâ obtusè biangnlatâ; costâ umbonali satis conspieuî; ligamento prominente; dente laterali magno, approximato.

Suboval, moderately strong, inequilateral, convex, glossy, whitish both within and without, with a few concentric and crowded minute oblique strix, which do not extend to the obtuse limder extremity, but are replaced before reaching the distinet umbonal ridge, by not very close subimbricated striæ (obsolete in one of the valves); ventral edge straightish; dorsal not greatly sloping on either side, convex in front, short and retuse behind; anterior side the longer, rounded; ligament promiment; lateral tooth large, approximate.

West Indies.

we f. 260.) Say, Jour. Acad. Philad. vol. v.

T. testâ 'T. simili simillimî, sed minore, magis convexî, magis inequilatcrali, radiis angustis roscis ormatâ ; margine eardinali roseo sub ligamento.

Very like a roung Simitis (of which it may possibly prove a varicty), but decidedly more comex than specimens in that stage, and when adult much more incruilatcral than full grown shells of 
the preceding species; delicately coloured by narrow lighter or darker tinged crimson rays, and the linge margin stained with rose-colour beneath the ligament; ventral edge decidedly convex.

Honduras (Dyson); Florida.

121. Teldina iris (pl. lxvi. f. 267.) Say, Jour. Ac. Nat. Sc. Philad. vol. ii.

T. testâ subovatâ, solidiusculâ, valdè inæquilaterali, nitidâ, satis convexâ, extus intusque albidâ, anticè radio subluteo obsoletè pictâ, striisque obliquis confertis utrâque in valvulâ insculptâ ; margine ventrali anticè subarcuato, posticè sursum acclinato; dorsali utrincue convexiusculo, anticè declivi, posticè valdè declivi; extremitate anticî rotundatâ; latere postico brevi, cuneiformi ; flexurâ costâque umbonali subinconspicuis; dentium lateralium antico subapproximato, postico subobsoleto.

Subovate, tolerably strong, very inequilateral, moderately convex, glossy, white both within and without, with a yellowish anterior indistinct ray at the umbones, and very distinct and numerous oblique strix, which in both of the valves reach even to the but little prominent umbonal ridge; ventral edge subarcuated in front, and rising posteriorly; dorsal edges moderately convex, sloping, the linder one particularly so; front extremity rounded; posterior side short and werlge-shaped; front lateral tooth distinct and rather close, hinder almost obsolete.

Carolina to Georgia, United States.

Very closely resembling $T$. similis from which it may be distinguished by the much greater slope of its dorsal edges, its pointed posterior termination, the greater extension of its oblique strix, and the presence of a second (though indistinct) lateral tooth. Mr. Say adds, "it has generally a rosaceous disk and one or two posterior (i.e. anterior) rays."

122. Tellina iridescens (pl. lviii. f. 88.); Sanguinolaria, Benson, Annals Nat. Hist. 1842. vol. ix.

T. testâ oblongâ, solidiusculâ, nitidâ, subæquilaterali, convexiusculâ, lævigatâ, albido-aurantiâ (iutus aurantiî), cpidermide tenuissimâ subirridescente inclutâ; margine ventrali subrecto; dorsali anticè subrecto paululumque declivi, posticè vix convexo et valdè declivi ; extremitate anticâ rotundatî ; latere postico, vix breviore, cuneiformi; ligamento haud prominente; flexurâ costâque umbonali obsoletis; dente laterali parvo, approximato.

Oblong, moderately strong, tolerably convex, subequilateral, smooth, glossy, pale orange, covered by a very thin slightly irri- 
descent epielermis; ventral edge nearly straightit; anterior side slightly the longer, rounded at its extremity, its dorsil edge scarccly convex and strongly sloping; ligament not prominent; fold and flexurc obsolete; inside orange, a single snall approximate lateral tooth.

Cliusan, China.

I liave received the sjecies from Dr. Philippi witl the proposed name of T? carnea, but know not whether he has subsequently published it.

- 123. Teluna fabula (pl. lvii. f.62.) Gmelin, 3239 ; Donov. Brit. Shells. vol. iii. t. 97 ; Wood, Gen. Conch. p. 156. t. 45. f. 4 ; Lam. no. 24; Philip. En. Mol. Sic. p. 26 ; IIanl. Des. Cat. p. 64. t. 3. f. 23.

T. testâ ovato-oblongâ, tenui, compressî, nitidî, cxtus intusque candidâ, subrquilatcrali, anticè rotunditâ, posticè cunciformi; valvulî alterî lævigatî ; margine ventrali subrecto, posticè sursum acclinato; dorsali anticè subdeclivi et convexo, posticè declivi et juxta ligamentum prominens retuso, deinde magis minusve convexo ; flexurâ obsoletâ ; dente laterali approxinato, distincto.

Ovate-oblong, thin, compressed, glossy, white within and without, nearly equilateral, rounded in front, wedge-shaped behind; one valve smootli, the other with crowded oblique striæ; ventral edge nearly straight, and rising posteriorly; front dorsal margin moderately sloping and convex, posterior one declining and near the prominent ligament retuse, but afterwards more or less convex; lateral tooth approximate, distinct.

Britain, Europe.

T. fragillissima of Chemnitz, vol. vi. f. 101, (T. vitrea of Gmelin), is usually considered as a bad representation of this species.

- 124. Teldina tenuis (pl. lviii. f. 81, 82.) Da Costa, Brit. Conch. p. 210. Wood. Gen. Conch. p. 155. t. 44. f. 3, 4.; Mont.'Tes. Brit. 1. p. 59.; Lam. no. 25. Hanl. Des. Cat. p. 64. t. 3. f. 22.; Plilip. En. Mol. Sic. 1.p. 27.; T. balaustina, Dillw. D. Cat. p. 93.

T. testâ ovali, tenuiusculî, compressî, nitidissimî, subæquilaterali, intus extusque albâ, aurantiâ aurantio-rubrî aut rosê̂, lævigatî; margine ventrali anticè convexo, posticè sursum acclinato; dorsali anticè convexo subleclivi, posticè declivi et juxta ligamentum prominens retuso ; latere antico paulo longiore, rotundato ; antico obtusè angulato; flexurî costaque umbonali subinconspicuis; dente laterali minimo, approximato. 
Var. (T. exigua, Poli. 'T'rst. Sicil. 1. t. 15. f. 15, 17.) testâ abbreviatî et idcirco margine dorsali utrinque magis declivi ; Hexurâ ommino obsoletî.

Oval, thinnish, compressed, extremely glossy, subequilateral, smooth both within and without, of an orange, white, orange-red, yellow or rose colour; the ventral edge convex in front, straightish and ascending behind ; anterior side rather the longer, rounded, its dorsal edge moderately sloping; posterior extremity obtnsely angulated; ligamental edge sloping, at first retuse, then rather convex ; ligament prominent ; fold and flexure not quite obsolete ; lateral tooth very small, approximate.

Var. Shortened, the dorsal edges consequently more sloping; the flexure quite obsolete.

Britain, Europe.

I agrec with Dr. Philippi, in regarding the T. liyalina of Deshayes (Exped. Morea, t. 18. f. 12, 13, 14.), as a narrow variety of this very variable shell. 1844 .

125. Tellina uuvenilis (pl. lvii. f. 63.) Ilanley, Zool. Proc.

T. testâ ovatâ, subtrigonâ, tenui, pellucidâ. compressiusculâ, niticlâ, rubro-aurantiâ, læevigatâ, inæequilaterali; margine ventrali convexo aut convexiusculo; dorsali anticè subrecto et declivi, posticè convexo et valdè declivi; latere antico longiore, subattemnato, rotundato; postico brevi, et obtusè subcuneiformi ; flexur:̂ costâcue umbonali subobsoletis; ligamento satis conspicuo; dente laterali parvo.

Subtriangularly ovate, inequilateral, thin, pellucid, slightly compressed, smootl, glossy, orange-red; ventral margin more or less convex; anterior side the narrower, romded at the extremity, its dorsal edge nearly straight; posterior extremity short, and obtusely wedge-shaped, the ligamental edge being convex and abruptly sloping; ligament distinct; fold and flexure almost entirely obsolete; lateral tooth small.

Philippines.

126. Teluna lux (pl. lvii. f. 71.) IIanley, Zool. Proc. 1844.

T. testâ subovali, tenui, pellucidâ, compressî, nitidâ, aurantî̂, sublævigatâ, inæuuilaterali; margine ventrali convexiusculo ; dorsali utrinque subdeclivi, anticè convexinsculo, posticè brevi et incurvato; latere postico breviore, obtusissinè biangulato ; extremitate anticî obtusè rotundatâ ; flexurâ costâque umbonali obsolctis ; ligarmento prominente; dente laterali approximato, distiucto. 
Somewhat oval, thin, pellueil, compressed, inechilateral, nearly smooth, and of an uniform glossy orange-flesh colonr' the ventril margin morlerately convex ; the dorsal but little sloping on eithel' sille, but inoderately convex in front, incurved and short behind; anterior extremity obtusely rounded; the posterior side much the shorter, and very obtusely biangulated; fold and flexure obsolete; ligament prominent; lateral tooth distinct and approximate.

Philippines. 1844 .

127. Teldina vervalis (pl. Iviii. f. 84.) Hanley, Zool. Proc.

T. testâ subovali, tenuissimâ, compressiusculâ, pellucidâ, nitidissimâ, lævi, valdè inæquilaterali, albido-roseâ, utrinque rotundatâ ; margine ventrali convexiusculo, anticè sursum acclinato; dorsali utrinque paululum convexiusculo, posticè declivi, anticè vix minimè declivi; latere antico producto, postico brevi; flexurâ obsoletâ; dente laterali minimo, subapproximato.

Somewhat oval, extremely thin and pellucid, slightly compressed, very inequilateral, uniform glossy pink, rounded at botlı extremities ; margins slightly convex, the ventral rising in front, the anterior dorsal scarcely sloping; flexure obsolete; anterior side short and cuneiform; lateral tooth minute and nearly approximate.

Singapore. 184.

125. Telinna maculpta (pl. lx. f. 136.) Hanley, Zool. Proc.

T. testâ oblongo-elongatî, solidiusculâ, compressâ, æequilaterali, extus intusque candidâ ; sulcis confertis concentricè exaratâ, striisque temuissimis radiantibus (presertim posticè) decussatâ; ultra costam umbonalem subobsoletam subsquamosâ; margine ventrali elongato, subrecto; dorsali utrinque subrecto, subdeclivi; extremitate posticî̀ subbiangulatâ; flexurî̀ ventrali distinctâ; dente laterali quamplurimum approximato.

Elongated-oblong, tolerably solid, compressed, equilateral, extermally and internally white, with concentric crowded sulci, and most minute posterior radiating striula; beyoud the almost obsolcte umbonal ridge, the surface roughened by small scales or interrupted delicate lamellæ; ventral edge nearly straightit, and much elongated; dorsal margins nearly straight and but moderately sloping; hinder extremity somewhat biangulated ; ventral flexure distinct; lateral tooth extremely approximate.

Chiriqui, W. Columbia. 
129. Teluna Psamotela (pl. lx. f. 131.) Lamarck, no. 30. IJanl. Des. Cat. p. 65. sup. t. 14. 1. 6.

T. testâ oblongo-ovali, snbtenui, convexiusculâ, nitidâ, extus intusque pallidâ, lævi, inæquilaterali; margine ventrali convexiusculo ; dorsali utrinque subdeclivi, subrecto ; latere antico producto, subattenuato, rotundato; extremitate posticî obtusè biangulatî; ligamento satis prominente; flexurâ obsoletâ; dente laterali distiucto, subapproximato.

Oblong-oval, inequilateral, rather thin, moderately convex, glossy, smooth, both within and without of a very pale dull orange yellow ; ventral margin moderately convex; dorsal edges but moderately sloping, and nearly straight; anterior side produced, rounded, and rather attenuated ; ligament moderately prominent; flexure obsolete; lateral tooth distinct, approximated.

Hab. (?) Mus. Cuming and Walton.

130. Tellina (Tellinides) emarginata (pl.lvii.f. 70.) Sou. Tankerv. Cat. App. p. 3 ; Hanl. Des. Cat. p. 74. sup. t. 13, f. 55.

T. testî oblongâ, tenui, subinæquivalvi, convexiusculâ, niticlâ, pallidâ, radio brevi rubro-aurantio ntrinque ad umbones notatâ, lævigatâ, valdè inæequilaterali; margine ventrali subrecto, anticè sursum acclinato; dorsali anticè recto et subdeclivi, posticè convexo et valdè declivi ; latere antico producto, rotundato, attenuato; cxtremitate posticâ brevi, obtusâ, emarginatâ; flexurî obsoletî; dente laterali distincto, approximato.

Oblong, rather inequivalve, tolerably convex, glossy, very pale orange, with a short deeper tinged ray on either side of the beaks, smooth, subpellucid, very inequilateral, produced rounded and attenuated in front, obtuse short and emarginated behind; ventral and anterior clorsal edges nearly straight, the latter not much sloping; posterior dorsal much sloping and convex beyond the ligament; flexure obsolete; lateral tooth distinct, approximate.

Singapore.

The Oblonga of Guelin, (p. 2314. from Chemnitz, vol. 6. f. 87.) inay possibly prove to be this or the preceding, but the resemblance is not sufficiently exact for identification, the figure bearing a greater resemblance to Cumana, or Aurora, but the description of the teeth by no means coinciding with the linge of either.

131. Tellina (Tellinides) truncatula (pl. lvii. f. 69.) Sowcrly, Tankerv. Cat. $\Lambda_{1}$ p. p. 3 ; Hanl. Des. Cat. 1. 73. 
'T. testî 'T. Vestali simillimâ, sed fulvo-aurantî̀, valdè com-

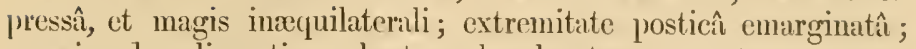
margine dorsali postico subretuso, hand autem excavato.

Very like Vestalis, but more compressed and inequilateral, of a tawny orange, with the linder extremity clearly notched, and the posterior dorsal edge not at all excavated, but simply and slightly retuse.

Ilo Ilo, Isle of Panay, Philippines (Cuming.) 1844.

132. Teluina vestalis (pl. Ivii. f. 67.) Manley. Zool. Proc.

T. testâ oblongo-angustâ, tenuissimâ, convexiusculâ, nitichâ, læri, intus extusque niveâ, inæquilaterali ; margine ventrali subrecto, pauInlum convexiusculo, anticè sursum acclinato ; dorsali anticè minimè declivi et pauluhum convexiusendo, posticè prope ligamentum excavato, deinde convexo et subdeclivi; extremitate lateris antici longioris rotundatâ; extremitate posticâ subemarginatâ, subattcmuatî, obtusè biangulatî ; flexurâ obsoletâ; dente laterali approximato.

Elongated-oblong, extremely thin, slightly convex, inequilateral, smootl, glossy, snowy white botl within and without; ventral margin but very sliglitly convex, and somewhat rising in front; anterior side rather the longer, its extremity rounded, its dorsal edge searcely convex and hardly at all sloping; hinder dorsal edge excavated at the ligament, afterwards convex and slightly sloping; posterior extremity rather attenuated, slightly emarginated, and obtusely biangulated ; flexure obsolete; the lateral tooth approxiinate.

Isles of Negros and Luzon, Philippines.

133. Teldina lanceolata (pl. lviii. f. 86, 87.) Chemnitz, vol. vi. p. 111. f. 103; Wood, Gen. Conch. p. 167. t. 45. f. 2; Ilaul. Des. Cat. p. 67. t. 4. f. 40 ; Psanmotrea pellucida, Lam. 110. 4; Deles. t. 5. f. 10.

'T. testâ oblongo-elongatî, tenui, compressâ, nitidiusculî, æquúlaterali, roseî aut albido-rosê̂, concentricè et confertissimè striattî, anticè rotundatî, posticè lanceolatî; margine ventrali subrecto; dorsali utrinque convexiusculo, anticè subhorizontali, posticè subdeclivi; costî̀ umbonali conspicuâ; liganento sutis prominente; costellî̀ internî ex umbonibus posticè radiante; dente laterali distiucto, subapproximato.

Elongated oblong, equilateral, thin, compressed, rather glossy, 
rose-coloured or white with a rosy tinge; concentrically striated, the stria extremely close; ventral edge nearly straight; clorsal but moderately convex on either side, ncarly horizontal in front, and not greatly sloping behind; anterior extremity rounded; posterior lanceolate; ligament tolerably prominent; fold conspicuous; an internal posterior radiating riblet; the lateral tooth distinet, subapproximate.

Isle of Negros, Philippines (Cuming).

134. Tellina hyalina (pl. lxi. f. 167.) Gmelin, 3235; Dillw. Des. Cat. p. 85 ; Hanl. Des. Cat. p. 67. t. 4. f. 39 ; T. complanata pellucida, Chem. vol. vi. f. 99.

T. testâ oblongâ, inæquivalvi, tenuissimâ, compressâ, valdè inaquilaterali, nitidâ, albidâ, subpellucidâ, lævigatâ ; margine ventrali convexo et posticè acclivi; dorsali posticè subrecto vixque declivi, anticè areuato et declivi; latere antico perbrevi, rotundato; postico producto, rotundato, attenuato ; natibus inconspicuis; ligamento infosso ; flexurâ obsoletî́ ; costellis duabus internis posticè radiantibus ; dente laterali quamplurimum approximato.

Oblong, inequivalve, very thin, much compressed, very inequilateral, of a brilliant smooth semi-transparent white; the ventral margin convex and rising behind; the hinder area of the dorsal edge, which is but slighitly convex and not greatly sloping posteriorly, and sloping and arcuated anteriorly, flattened; anterior side short and rounded; posterior side produced, rounded, and attenuated ; ligament sunken ; beaks not prominent ; fold obsolete; two internal rib-like lines radiating from the linge posteriorwards; the lateral tooth almost touching the primary ones.

The only perfect specimen I have ever beheld of this extremely rare shell, belongs to Dr. Bates, who most courteously forwarded it from the United States, for my inspection.

135. Tellina (Tellinides) Timokensis (pl.lxi. f.158, 172)

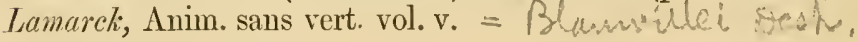

T. testâ oblongâ, tenuiusculî, subæquilaterali, compressiusculâ, nitidâ, subpellucidâ, extus intusque candidâ (nomnuncuam marginibus roseo tinctis) concentricè substriatâ, anticè rotundatî, posticè attenuatâ et supernè obtusè angulatâ; margine ventrali subrecto; dorsali utrinque subrecto et subrleclivi, anticè paululum convexiusculo, postieè subretuso ; flexurî̀ costâque umbonali obsoletis; ligamento magno, prominente; dente laterali, approximato.

Oblong, rather thin and semi-trinsparent, nearly equilateral, rather compressed, both within and without of a glossy white 
which is often tinged with yellow and rarely with rose-colour at the margins, concentrically substriated; the ventral edge nearly straight, and usually very indistinctly inflated belind; anterior side slightly the shorter, rounded at the extremity; posterior side rather attenuated, and obtusely angulated above; clor:al edges scarcely sloping and nearly straight, the front being very slightly convex, the hinder somewhat retuse; ligament large and prominent; umbonal ridge and fold quite obsolete; tectl distinct and generally tinged with rosc-colour, the lateral one approximate.

Isle of Negros, Plilippines; \&c.

\section{Teluina conspicua (pl. lviii. f. 100.) Hanley.}

T. testâ T. Timorensi simillimâ, sed abbreviatî, et ovali-subtrigonâ; margine dorsali utrinque magis declivi, posticè convexiusculo.

Very like Timorensis, but not so elongated; the dorsal edges much more sloping, and the front one not retuse.

This may eventually prove but a young variety of Simuata, but the only specimen I have ever secu (purchased with this name attached, and now in the collection of Mr. Cuming) lias been pronounced distinct by every Conchologist who has inspected it.

337. Teluiva sinuata (pl. lxiii. f. 203.) Spengler, loc. cit.; Tellinides Timorensis, Sow. Gen.; Reeve, Conch. Syst. t. 56. f. 2; Young, T. nivea, Wood, Gen. Conch. p. 177. t.46. f. 1; Dillwyn, D. Cat. p. 89 ; Index Test. t. 4. f. 92.

T. testâ subovali, solidiusculâ, inæc|uilaterali, compressiusculâ, niticlâ, extus intusçue albidâ, concentricè striolatî, striïsque obliquis anticis infernè decussatâ; margine ventrali subrecto, posticè sinuoso; dorsali anticè brevi subrecto declivi, posticè incurvato vixque declivi ; extremitate posticî latî, rotundatâ ; anticâ obtusâ; costâ umbonali obsoletâ; ligamento magno, prominente; dente laterali approximato.

Oval, rather oblique, tolerably strong, and somewhat compressed, glossy, whitish, with concentric strinlæ which are decussated in front by fine raised oblique and rather distant ones; ventral edge sinuated posteriorly, and somewhat swollen in the middle; anterior side clearly the shorter, its extremity obtuse, its dorsal edge nearly straight and moderately sloping; posterior extremity obtuse, rounded below, but forming a rounded-ofl' angle with the short concave and scarcely sloping dorsal margin ; ligament large and prominent; umbonal ridge obsolete; inside white, teetlo as in the last, but nerer tinged witl rose-colour.

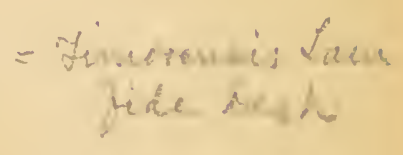


Closely allied to Timorensis, but differs in shape, sinuosity, and the decided inequality of its sides. The anterior oblique strix, which in some specimens extend along the ventral edge posteriorward, are rarely present in that species.

Tranquebar; Sumatra.

138. Tellina triangularis (pl.lx.f.150.) Chemnitz, vol.vi. p. 96. f. 85 ; Dillwyn, D. Cat. p. 79 ; Desh.ed.Lam. vol.vi. p. 209 ; Tellinides triangularis, Hanl. Des. Cat. p. 74. t.4. f.33; Tellinides politus Sow., Tanker. Cat. App. p. 4 ; 'T. trilatera, Gmel.; T. obliqua, Lam. no. 47.

T. testâ ovato-trigonâ, inæquilaterali, solidiusculâ, compressâ, nitidissimâ, sub epidermide flarescente-candidâ, anticè et prope marginem ventralem convexum concentricè striatâ, alterâque in valvulâ striis flexnosis obliquis posticè ornatâ; margine dorsali anticè brevi et arcuato, posticè subrecto et producto; extremitate posticâ obtusè acuminatâ; anticâ rotundatâ; ligamento prominente; flexurâ nullâ ; dente laterali approximatissimo.

Ovate-triangular, tolerably solid, compressed, inequilateral, both internally and externally white, the epidermis yellowish and very glossy; with concentric striæ in front, and towards the convex ventral margin which rises a little behind; anterior side rounded, its dorsal edge convex ; posterior side produced and obtusely acuminated, the dorsal edge nearly straight and very oblique; ligament prominent; flexure obsolete; the lateral tooth quite close to the beaks.

Molnceas? Mus. Cuming, \&c.

139. Tellina (Tellinides) aciminata (pl.lx.f.141.) Hanley, Des. Cat. p. 73. sup. t. 13. f. 53.

T. testâ elongatâ, subovatâ, solidiusculâ, valdè inæquilaterali et inæquivalvi, compressâ, politî, lævigatâ, extus intusque albidâ aut albido-aurantiâ; margine ventrali subarcuato; dorsali anticè subarcuato satisque declivi, posticè elongato subrecto et declivi ; latere antico breviore, rotundato ; postico valdè producto, acuminato, ad extremitatem rotundato ; ligamento infosso ; flexưuâ costâque umbonali obsoletis ; dente laterali approximato.

Elongated, subovate, moderately strong, very inequilateral and inequivalve, both valves compressed, but one much shallower than the other; smooth, polished, both within and without of a pale orange becoming white towards the subarcuated rentral edge; anterior side the shorter, rounded, its dorsal edge arched and moderately sloping; posterior sirle much produced, acuminated, 
with the tip rounded, the dorsal edge nearly straight, moderately sloping, and very long; ligament sunken; umbonal ridge and flexure obsolete; lateral tooth approximate.

Hab.? Mus. Britannicum.

140. Telutina planissima (pl. lix. f. 124. and pl. lxii. f. 197.) Anton, Verzin. Conch. p. 4 ; Ab. und Bes. Conch. part 5. t. 5. f. 2 ; Tellinides rosea, Sow. Gen. Shells, 1. 1; Reeve, Conch. Sỵst. t. 56. f. 1 .

T. testâ ovatâ, tenuiusculâ, inæquivalvi, inæ(quilaterali, compressî, extus intusque rosê̂, concentricè substriatấ; margine ventrali convexiusculo; dorsali utrinque declivi, anticè convexo, posticè subrecto; latere antico rotundato; postico longiore, rotundato-cuneiformi; ligamento prominente; flexurâ subobsoletâ; costellâ internâ in valvulâ complanatâ posticè radiante; dente laterali parvo, approximato.

Var. Candida.

Ovate, rather thin, inequivalve, inequilateral, compressed, rosecoloured both within and without, concentrically substriated ; ventral margin moderately convex, the flexure not quite obsolete; dorsal edges sloping, the anterior convex, the posterior nearly straight; anterior extremity rounded; posterior side the longer and of a roumded wedge-shape; ligament prominent; an internal rib radiating posteriorward in the flattened valve; lateral tooth small, approximate.

Var. Quite white.

Moluccas.

The Opalina of Chemnitz is closely allied to, if not identical with, the white variety of this shell.

141. Teline (Telminides) purpurascens (pl. lxii. f. 194.) Broderip and Sowerly, Zool. Jour. vol. iv. p. 363 ; Hanl. Des. Cat. p. 74. sup. t. 9. f. 1S; Zool. Beechey's Voy. t. 42. f. 2. , 2 th xe.

T. testâ oblongo-ovali, tenui, compressî, niticlinsculî, subæequilaterali, roseo-purpurascente, pellucidâ, striis radiantibus et concentricis confertissimè decussatî ; margine ventrali convexiusculo; dorsali utrinçue paululum dechivi, anticè convexiusculo, posticè subrecto; latere antico minimè longiore, rotundato; extremitate posticâ subangulatî, subemarginatî; ligamento prominente; flexurî omnino obsoletî ; dente laterali approximato.

Oblong-oval, thin, compressed, rather glossy, nearly equilateral, purplish-rose coloured, pellucid, decussated by most crowded radi- 
dorsal but little sloping on either side, slightly convex in front, nearly straight behind; anterior side very slightly the longer, rounded; posterior extremity subangulated, subemarginated; ligament prominent; flexure quite obsolete; lateral tooth approximate.

Real Leijos, Central America (Cuming).

142. Teluiva (Teluinides) ovalis (pl.lx. f. 147.) Sowerly, Tank. Cat. App. p. 3 ; Hanl. Des. Cat. p. 73. sup. t. 13. f. 56 ; T. tridentata? Anton, in Wiegm. Arch. 1837.

T. testâ ovali, tenuissimâ, pellucidâ, subæquilaterali, compressâ, nitidâ, rosen̂, radiis angustis albidis frequentibus ornatâ, concentricè substriatâ; margine ventrali convexiusculo ; dorsali utrinque paululum declivi; latere antico longiore, rotundato; extremitate posticâ olstusâ, aliquantulum latiore ; flexurâ costâque umbonali obsoletis; natibus inconspicuis; ligamento prominente; dente laterali approximato, distincto.

Oval, pellucid, subequilateral, compressed, extremely. thin, concentrically substriated, and variegated with crowded narrow whitish rays on a rose-coloured ground; the ventral margin slightly convex; the dorsal but little sloping on either side, the ligament edge slightly retuse; posterior extremity obtusely rounded, and ratlier broader than the rounded termination of the more elongated anterior side; fold and flexure obsolete; beaks not prominent; ligament projecting; a distinct approximate lateral tooth.

Noluccas; San Nicolas, Zebu; (Cuming).

The Solen striutus, of Gmelin (from Chemnitz, vol. vi. f. 57,58.), seems closely allied if not identical.

143. Tellina coccinea (pl. lviii. f. 90.) Chemnitz, vol. vi. p. 11s. f. 109 ; Dillw. Des. Cat. p. 87 ; Tellinides coccinea. Hanl. Des. Cat. p. 74. t. 4. f. 42.

T. testâ ovali, tenuissimâ, compressâ, æquilaterali, pellucidâ, roseo-purpurascente, ntrinque rotundatâ ; concentricè striatâ, striis anticis frequentibus, posticis remotis et subimbricatis; margine ventrali convexiusculo ; dorsali utrinque panlulum declivi ; flexurâ costâque umbonali obsoletis; ligamento prominente; costellis duabus internis (in junioribus) posticè radiantibus ; dentibus primariis subobsoletis, dente laterali approximato, distincto.

Oval, compressed, very thin, equilateral, of an uniform pellucid purple-rose colour, with concentric striæ which are crowded in front, but distant and subimbricated behind; the ventral edge morlerately convex; the dorsal but little sloping on either side of 
the little prominent beaks; extremities rounded and nearly equally broad; the fold and Hlexure obsolete; the ligament prominent; two rather indistinct internal rib-like lines radiating (in the young only) posteriorward; cardinal teeth nearly obsolete, the approximate anterior lateral very distinct (when young).

San Nicolas, Zebu (Cuming). 1844 .

144. Teldina rhodon (pl. lviii. f. 93.) Hanley, Zool. Proc.

T. testâ oblongâ, tenuissimâ, compressiusculâ, nitidissimâ, lævi, roseâ, pellucidâ, valdè inæquilaterali, utrinque rotundatâ ; margine veutrali convexiusculo, anticè sursum acclivi; dorsali anticè convexiusculo et vix declivi, posticè subdeclivi; latere postico brevi subattenuato; natibus inconspicuis; flexurâ costâque umbonali obsoletis ; dente laterali approximato.

Oblong, very inequilateral, extremely thin, rather compressed, smooth, polished, and of an uniform purplish rose-colour; the ventral margin slightly convex, and rising in front; the dorsal but slightly convex on either side, scarcely sloping in front, but moderately so behind; the extremities rounded, and the shorter posterior side somewhat attenuated; beaks not prominent; the fold and flexure obsolete; lateral tooth approximate.

- Hab. ? Mus. Cuming.

145. Tellina Oudardi (pl. lxvi. f. 262.) Payraud. Cat. Corse, p. 40. t. 1. f. 16, 17, 1S; Desh. ed. Lam. vol, vi. p. 210 ; Hanl. Des. Cat. p. 65. sup. t. 14. f. 8.

“T. testâ ovatâ, compressâ, nitidâ, pellucidâ, obliquè cancellatâ, lineis transversis albis parvulisque longitudinalibus rubris ornatâ; anticè et posticè radiis luteo-rubescentibus; intus et extus rubrâ.

Ovate, compressed, glossy, transparent, obliquely cancellated, adorned with transverse white lines and small longitudinal red ones; rays of a yellowish red both in front and behind; red botls within and without."

I have been obliged to content inyself with reprinting the original description, and giving a representation of the typical shell deposited in the Museum at Paris, as I am unable to procure a specimen in England for the purpose of comparison. Had it not been for the mention of sculpture on the surface of one of its valves, I should have doubted its distinctiveness as a species. "The valves are furnished with transverse strix in lozenges, accompanied by a multitude of silvery-white little rays both which are crossed by very delicate longitudinal lines of a deeper red than the 
ground-colour of the shell." There seems from the drawing to be but a single anterior moderately distant lateral tooth, and no erternal appearance of rays in the front of the shell. The sculpture must indeed be minute, to lave escaped the attention (as it has) of our very accurate artist.

\section{Teluiva subrosea (pl. lvii. f. 64.) Hanley.}

'T. testâ oblongî, tenuissimâ, compressâ, valdè inæquilaterali, roseâ, pellucidâ, lævi, nitidâ, posticè breviore et obtusè cuneiformi, anticè obtusâ ant rotundatâ; margine ventrali subrecto; dorsali anticè paululum declivi, posticè declivi, utrinque subrecto aut conrexiusculo; Hexurâ inconspicuâ; dente laterali subobsoleto, approximato.

Oblong, extremely thin, compressed, smooth, pellucid, rosy, very inequilateral and highly glossed; ventral margin straightish; dorsal edges straightish or but slightly convex, very slightly sloping in front, moderately so behind; anterior extremity rounded or obtuse; posterior side the shorter and obtusely wedge-shaped; flexure very inconspicuous; lateral tooth approximate and almost obsolete.

Catbalonga, Isle of Samar, soft mud; (Cuming).

The specimens closely resemble the young of the Punicea group, but both locality and dentition are adverse to this conclusion. They appear, however to be scarcely adult.

147. Tellist margaritisa (pl. livi. f. 257.) Lam. no. 15; Deless. Rec. t. 6. f. 4.

T. testâ ovali, tenui, pellucidâ, nitidâ, margaritaceâ ; latere antico (postico) attenuato.

Oval, thin, transparent, glossy, nacreous white, front (hinder) side attenuated.

New Holland.

The representation of the species in Delessert's magnificent folio, enables me to refer this shell to the present division. I an unable, however, to add a more lengthened description than the rery meagre outline furnished in the 'Animaux sans vertèbres'. The only specimens I have ever seen were the original types of the French IIuseum; but they sufficed to convince me of the clear distinctness of the species from any possessing a similar dentition.

* * Devoid of lateral teeth.

145. Teluisa Cumana (pl. lviii. f. 73.) Psammobia Cumana, 
Costa Cat. T'est. Sicil. 20. t. 2. f. 7.; Tellina Costæ Philip. Èn. Mol. Sic. 1. p. 25. t. 3. f. 11.

T. testâ oratâ aut orali-oblongâ, tenuiusculâ, inæquilaterali, valdè convexâ, subnitidâ, lærigatâ, extus intusquc albidâ, nmbonibus hyalinis et plerumque pallidè aurantiis ; margine ventrali satis convexo ; dorsali utrinque subrecto, posticè satis, anticè paululum declivi; latere antico longiore ad extremitatem rotundato; postico angustato, obtusè subtruncato; natibus acutis, et rectè incurvatis ; costâ umbonali satis distinctâ, haud autem conspicuâ; ligamento infosso ; dentibus parris.

Varring from orate to oval-oblong, rather thin, inequilateral, not very glossr, smooth, both within and without whitish, with the umbones usually hyaline and often tinged with orange; rentral edge moderately convex, but not arcuated; dorsal edges nearly straight, sloping behind, and but moderately so in front; anterior side the longer and rounded at its termination; posterior side narrowed, and obtusely subtruncated; beaks acute and not inclining to either side; ligament sunken, umbonal ridge not prominent but tolerably erident; teeth small.

Very closely resembling Plebeia, but proportionally more ventricose, with the ventral edge less arcuated, \&c.

Mediterranean.

- 149. Tellina plebela (pl. lix. f. 129, and f. 151.) Hanley, 'Zool. Proc. 1814.; Psammobia lærigata (?) Lamarck.

T. testâ suboratâ, solidiusculâ, convexâ, subnitidâ, lærigatâ, intus extusque, albidâ, umbonibus hyalinis et rubro-aurantiis; margine ventrali convexo aut subarcuato; dorsali anticè prope nates recto et paululum declivi, posticè recto satisque declivi; latere antico longiore, rotundato ; extremitate posticâ obtusè angulatâ ; ligamento infosso ; costâ umbonali conspicuâ; flexurâ obsoletâ. Var. Ovatâ ; castâ umbonali minus conspicuâ ; umbonibus sæpe albidis.

Suborate, tolerably strong, convex, not very glossy, smooth, both within and without whitish, with the umbones hraline and orange-red; rentral edge convex or subarcuated; anterior side the longer, rounded, its dorsal edge strajght and scarcels sloping near the beaks; posterior extremity obtusely angulated, the ligannental edge straight and sloping; ligament sunken; flexure obsolete.

Tar. (from Africa) orate, the rentral edge more regularly arcuated, the fold less prominent, and the umbones often colourless.

Real Lejjoc, Central America; Senegal. 
150. Telitina umbonelda (pl. lvi. f. 13.) Lamarck, no. 48. Hanl. Des. cat. p. 70.

T. testâ obovali, solidiusculâ, subinæquilaterali, convexâ aut convexiusculâ, subimpolitâ, extus intusque albidâ, umbonibus hyalinis et roseo tinctis, epidermide tenui fugaci cinerascente indutâ, lævigatâ; margine ventrali convexo aut subarcuato; dorsali utrinque subrecto et paulo declivi; latere antico paulo longiore, rotundato; postico subangulato; natibus haud prominentibus; ligamento infosso ; costâ umbonali obsoletâ ; dentibus minimis.

Oboval, tolerably strong, slightly inequilateral, merely convex, not glossy, both within-and without whitish under a thin ashy epidermis, with the beaks somewhat hyaline and tinged with rose-colour, smooth or with a few antiquated lines; ventral edge decidedly convex; the dorsal edges but little sloping, and nearly straight; anterior side rather the longer, rounded at its extremity; posterior side subangulated; ligament sunken; beaks not prominent; unbonal ridge obsolete; teeth minute.

Very like Plebeia in all but the shape, which is much more elougated in that species.

Port Lincoln, Australia.

151. Tellina nobilis (pl.lx. f. 143.) Manley,Zool.Proc. 1844.

T. testâ ovali, solidiusculâ, convexâ, inæquilaterali, nitidissimâ, intus extusque roseâ, lævigatâ; margine ventrali convexiusculo medio plerumque subrecto; dorsali anticè convexiusculo et vix declivi, posticè subdeclivi et subrecto aut convexiusculo; latere antico longiore, ad extremitatem obtusè rotundato; postico obtusè angulato; natibus obtusis ; flexurâ costaque umbonali subobsoletis ; ligamento prominulo; dentibus parvis.

Oval, tolerably strong, convex, inequilateral, very glossy, smooth, rosy within and without; ventral edge moderately convex; dorsal tolerably convex and scarcely sloping in front, moderately sloping and varying from straightness to slight convexity beluind; auterior side the longer, obtusely rounded at its extremity; posterior side obtusely angulated; fold and flexure nearly obsolete; ligament rather prominent; beaks obtuse; teeth small.

Luzon, Pliilippines. 1844

152. Telitna lucerna (pl. Iviii. f. 98.) Hanley, Zool. Proc.

T. testâ oblongâ, solidiusculâ, subventricosî, nitidiusculâ, lævigatâ, albidâ, umbonibus aurantiis, anticè longiore et rotundatâ, posticè obtusè cuneiformi, margine ventrali subrecto; dorsali pos- 
ticè declivi, anticè paululum declivi, utrinque subrecto; flexurî obsoletâ; ligamento subinfosso ; disco interno anrantio.

Oblong, tolerably solid, rather ventricose, slightly glossy, smooth, whitish, with the umbones ormge, anteriorly longer and rounded, posteriorly obtusely wedge-shinped; rentral and dorsal edges straightish, the latter posteriorly sloping, anteriorly scarcely sloping; flexure obsolete; ligament rather sunken; inner dise orange.

Isles of Negros, Mindanao, and Panay.

153. Teluina aurora (pl. lviii. f. 76.) Hantey, Zool. Proc. 184t.p. 147 .

T. testâ T. Psammotella simillimâ, convexiore autem, ct umbonibus rubro-aurantiis; ligamento infosso; dentibus lateralibus nullis.

Very like T. Psammotella but more convex, and with the umbones of an orange-red. The ligament too is sunken and the hinge devoid of lateral teeth.

Panama.

154. Teldiva Galatea (pl. lxiv. f. 223.) Psammobia Galatæa Lam. no. 1S; Hanl. Des. Cat. p. 58. sup. t. 13. f. 44. 'T. Sericina Jonas, Ab. mud. Bes. Conch. part 3. t. 5. f. 1.

T. testâ oblongâ, solidiusculâ, convexâ, valdè inæquilaterali, subnitidâ, extus intusque candidâ, punctis minutissimis elevatis confertis radiation asperatî; margine ventrali subrecto; dorsali anticè subhorizontali, posticè brevi reeto et declivi; latere antico producto, rotundato ; extremitate posticâ truncato-cuneiformi ; ligamento infosso ; Hexurâ obsoletâ ; dentibus parvis.

Var. ('T. Diana, Zool. Proc. 1S44.) subovatî, punctis obsoletis; margine dorsali utrinque magis declivi; extremitate postieâ magis obtusâ.

Oblong, tolerably strong, convex, very inequilateral, rather glossy, white within and without, roughened by crowded radiating rows of minute raised dots; ventral edge nearly straight ; anterior side produced, rounded at the extremity ; dorsal edge convex and nearly horizontal; posterior side of a truncated wedge-shape ; the ligamental edge straight, short, and much sloping; ligament sunken; flexure obsolete; teeth very small.

Var. Subovate, the dots obsolete; dorsal edges more sloping; posterior end more obtuse.

China.

- 155. Telma candina (pl. lxii. f. 195.) Psammotai candida Lam. no. 6. Hanl. Des. Cat. p. 60. 
T. testâ elongato-oblongâ, subæuuivalvi, maximè inæquilaterali, extus intusque candidâ, lævigatâ, convexâ aut subventricosâ; margine ventrali posticè convexiusculo, anticè arcuato et sursum acclinato; dorsali auticè convexiusculo paululımque declivi, posticè retuso et valdè declivi, extremitate anticâ rotunclato-attenuatâ; latere postico brevissimo, obtusè cuneiformi ; ligamento subinfosso; costâ umbonali subobsoletâ; dentibus minimis.

Elongated-oblong, subequivalve, extremely inequilateral, white both within and without, convex or snbventricose, smootl, with however obsolete radiating lines, and very indistinct striulæ towards the ventral margin, which latter is straightish behind, but curves upward in front, so as somewhat to attenuate the rounded anterior extremity ; front dorsal edge scarcely at all sloping, rather convex ; posterior side very short and obtusely wedge-shaped, the dorsal edge retuse and decidedly sloping; ligament rather sunken; fold nearly obsolete; teeth minute.

Clina (?) Mus. Metcalfe.

Very closely allied to Galatiea, but narrower, more convex, and utterly devoid of those radiating lines of raised dots, which are so characteristic of that species. The posterior extremity is more regularly cuneiform, and the anterior termination more attenuated. 1844

156. Tellina eloxgata (pl. lxii.f. 199.) Hanley, Zool. Proc.

T. testâ elongatâ, angustî, tenuiusculâ, satis convexâ, extus intusque candidâ, lævigatî, valdè inæquilaterali; margine ventrali medio subretnso, anticè obliquè arcuato; dorsali anticè subhorizontali et subrecto, posticè subdeclivi et subretuso; extremitate lateris antici longioris obtusâ posticî aeuminato-truncatâ; ligamento infosso ; flexurâ obsoletâ; dentibus parvis.

Elongated, narrow, thinnish, moderately convex, smooth, white, very inequilateral; ventral edge rather retuse in the middle, and obliquely arcuated anteriorly; anterior side the longer, its extremity obtuse, its dorsal elge almost horizontal and nearly straight; hinder extremity with a truncated acumination, the ligamental edge slightly incurved and moderately sloping; flexure obsolete; ligament surken ; inside white; teeth small.

Chiriqui, West Columbia. 1844.

157. Tellina assimluis (pl. lviii. f. 95.) Ilanley, Zool Proc.

T. testâ T. elongatæe simillimâ, convexiore autem, et latere postico obtusc̀ cuneiformi paululumąue subrostrato. 
Closely resembling a young Elongata, but more convex, and the hinder side obtusely wedge-shaped and slightly beaked; the hinder extremity not in the slightest degree truncated, but the ligamental edge sweeping to the lower margin in a concave and then convex curve.

Luzon, Philippines. 184.4 .

158. Teldina ulium (

T. testâ ovato-oblongî, tenuiusculâ, convexâ aut subventricosâ, extus intusque albâ; concentrieè substriatâ, striis supra costam umbonalem elevatis; margine ventrali subreeto anticè sursum acclinato; dorsali anticè subrecto paululumque declivi, posticè valdè dechivi et prope ligamentum prominulum reeto deindeque convexo; extremitate lateris antici producti infernè et obliquè rotundatâ; cxtremitate posticâ brevi, cumeiformi.

Ovate-oblong, rather thin, convex or subventrieose, white both within and without, with concentric striula, and obsolete radiating lines, which latter are most pereeptible in the younger specinens, the striulæe elevated upon and beyond the tolerably distinct fold; anterior side produced, its dorsal edge nearly straight, and scarcely sloping, its extremity obliquely rounded near the straight ventral margin; posterior side short and wedge-shaped; the ligamental edge straight, but convex at the extremity; ligament small, and moderately prominent.

Isles of Burias and Negros, Philippines.

159. Telliva tenta (pl. lxvi. f. 266.) Say, Am. Conch. t. 65. f. 3; Gould, Tnvert. Massach. p. 68. f. 43.

T. testâ oblongâ, tenuissimâ, snbflexuosî, convexiusculâ, extus intusque albidâ, lævigatî, valdè inæquilaterali; margine ventrali subrecto; dorsali anticè convexo (aut subarcuato) et paululum declivi, posticè retuso et subdeclivi; latere postico brevi, ad extremitatem angustato et paululum subrostrato ; extremitate auticû rotundatâ; costâ umbonali subinconspiculî; ligamento parvo, prominente; superficie intcrnâ lincis radiantibus ornatâ ; dentibus minimis.

Oblong, very thin, rather flexuons, moderately convex, whitish, very inequilateral, very nearly if not quite smooth, rentral margin straightish; front dorsal elge convex or subarcuated, and very little sloping; linder one retuse and moderately sloping; posterior side short, narrowed and very slightly beaked at its termination, the tip truncated or subemarginated; anterior end rounded; fold 
not very conspicnous; ligament small, projecting; inside whitish, and distinctly marked with radiating lineoles; teetlı very small.

Boston. $18+1$.

160. Teldiva ancilla (pl. Miiii. f. 94.) Hanley, Zool. Proc.

T. testâ oblongo-elongatâ, temuiusculâ, satis convexâ, nitidissimâ, extus intusque candidâ, concentricè substriatâ, lineisque obsoletis radiantibus ornatâ ; striis supra costam umbonalem subobsoletam remotioribus, distinctis, subimbricatis ; margine ventrali subrecto ; dorsali anticè subdeclivi et convexiusenlo, posticè subrecto et declivi; extremitate lateris antici producti rotundatâ; latere postico breviore, obtusè cuneiformi.

Elongated-oblong, thimnish, moderately convex, very glossy, pure white both within and without, with concentric striulæ, which are most perceptible at the nearly straight ventral margin, and become subimbricated distinct and rather distant upon and beyond the almost obsolete fold ; anterior side produced, its extremity rounded, its dorsal edge slightly convex and not much sloping; posterior side obtusely wedge-shaped, ligamental edge straightish, tip rounded.

Lord Hood's Island.

161. Tellina Bodegersis (pl.lix. f.102.) Hinds, Zool. Sulphur, vol. ii. t. 21. f. 2. p. 67.

T. testâ oblongo-elongatâ, inæquilaterali, solidiusculâ, compressâ, nitidâ, extus intusque candidâ, concentricè et subimbricatim sulcatâ; margine ventrali subrecto, anticè sursum acelinato; dorsali utrinque subrecto, anticè vix minimè declivi; latere postico breviore, cuneiformi ; extremitate anticâ rotundatâ; flexurî obsoletâ ; ligamento satis prominente; dentibus lateralibus nullis.

Elongated-oblong, inequilateral, rather solid, compressed, of a glossy ivory white, with regular moderately distant concentric subimbricated sulci, (which in the only specimen I have ever seen disappear in one valve at the posterior end); the ventral margin nearly straight, rising in front, the anterior dorsal scarcely at all sloping; posterior side the shorter, wedge-shaped; front extremity rather obtusely rounded; fold and flexure obsolete; ligament moderately projecting; inside white; no lateral teeth.

Russian Bodejas.

162. Tellina Rhomboides (pl. lviii. f. 92, 96, 97.) Quoy and Gaim., Voy. Ast. Zool. vol.iii. p.502. t.81. f.4-7 ; T. clathrata, 
Desh. Lam. vol. vi. p. 208; Hanl. Des. Cat. p. 65. sup. t. 14. f. 12.

T. testâ ovali-oblongâ, solidiusculî, valdè inæquilatcrali, magis minusve convexâ, subnitidî, albidî, pallidè luteâ, aurantiâ aut albido-roseâ, striis anticè concentricis et medio obliquis confertim ornatâ; margine ventrali subrecto aut paululum convexo ; dorsali anticè subrecto et paululum declivi, posticè satis declivi; extremitate lateris autici producti obtusè rotundatâ; extremitate posticâ magis ninusve obtusè cuneiformi ; ligamento prominente; Hexurû vix perspicuâ.

Var. Pallidè luteâ, radiis angustis roseis ; striis obl quis majoribus et fortioribus.

Oval-oblong, very inequilateral, tolerably strong, more or less convex, rather glossy, whitish pink, pale yellow, or orange, with very delicate striæ, which are concentric in front but become oblique in the middle; ventral edge straightish, or not much convex; anterior side produced, its extremity rounded, its dorsal edge straightish and but little sloping; posterior side rather variable in shape, but short, and more or less obtusely wedge-shaped; ligament prominent; flexure not quite obsolete.

Var. Pale yellow with narrow rosy rays, the oblique striæ larger and strouger.

Isles of Zebu and Ticao, Philippines, (Cuming). 1544 .

163. Telliva formosa (pl. lviii. f. S3.) Hanley, Zool. Proc.

T. testâ obovatâ, solidiusculâ, nitilk̂̀, convexiusculî, subpellucidâ, albidâ, radiis interruptis roseis striisque minutis obliquis confertis undique ornatâ; margine ventrali convexo; dorsali utrinque convexiusculo, anticè subdechivi, posticè valdè dcclivi; extremitate lateris antici producti rotundatî, lateris postici brevissimi obtusissimè angulatâ; natibus roseis; ligamento parro et satis prominente; flexurâ subobsoletî.

Obovate, moderately strong, glossy, scarcely convex, somewhat pellucid, white, with numerous narrow rosy interrupted rays, and crowded minute oblique strix; ventral margin convex; dorsal moderately convex on both sides, little sloping in front but greatly so behind; anterior side produced, its extremity rounded; posterior side short, its extremity very obtusely angulated; beaks rosy ; ligament small, moderately prominent; Hexure nearly obsolete.

Dalegnete, Zebu. 
164. 'l'ellisa dispar (pl. lix. f. 108, 113, 114.) Conrad, Jour. Ac. N. S. Philad. vol. vii.

T. testâ ovatâ, solidiusculâ, satis convexâ, nitidâ, candidâ aut roseâ, subæquilaterali, posticè breviore et obtusè angulatâ aut obtusissimè cuneiformi, anticè rotundatâ ; alterâ valvulâ lævi, alterâ striis tenuissimis anticè concentricis deinde obliquis confertim ornatî; margine ventrali convexiusculo; dorsali utrinque haud multum declivi aut convexo; ligamento prominente; flexurâ obsoletâ.

Ovate, tolerably strong, moderately convex, glossy, white or rose-coloured, nearly equilateral, rounded in front, rather shorter and very obtusely wedge-shaped or obtusely angulated behind; one valve smooth, the other with fine strix, which are concentric in front and then become oblique and crowded; ventral margin but slightly convex; dorsal edges not greatly sloping or convex; ligament prominent; flexure obsolete.

Sandwich Isles; and Isle of Bohol, soft mud, eight fathoms, (Cuming).

In some specimens there is a tinge of rose-colour near the dorsal edges.

165. Tellina lutea (pl. lix. f. 103, and lxv. f. 249.) Gray $(1828$ )

in Index Test. Sup. t. 1. f. 3 ; Hanl. Des. Cat. p. 67. sup. t. l. f.3.

T. Guildfordiæ, Gray in Grif. Cuvier, Mol. t. 19. f. 2.

Young; T. alternidentata, Brod. and Sow., Zool. Jour. vol. iv. p. 363 ; Zool. to Beechey Voy. t. 44. f. 5.

T. testî orali-subtrigonâ, subæquilaterali, subinæquivalvi, compressiusculâ, sublævigatâ, albidî̀ aut pallidè roseâ,, epidermide subviridi fugaci (in jumioribus) indutâ, anticè rotundatâ; margine ventrali subrecto aut convexiusculo; dorsali anticè subdeclivi et convexinsculo, posticè declivi et prope ligamentum magnum subretuso deindeque convexo ; latere postico obtussissimè cuneiformi ; natibus erosis; flexurâ obsoletâ; superficie internâ albido-roseâ, utrinque saturatius fucatâ, ant roseo subradiatâ; dentibus primarïs in utrâque valvulî̀ duobus, altero simplici, altero bicuspidato, alternatim inter se insertis.

Oral-subtriangular, subequilateral, rather compressed, slightly inequivalve, nearly smooth, whitish or pale rose-colour under (in young specimens only) a thin fugacious greenish epidermis; ventral edge but slightly (if at all) convex; anterior side rounded, its dorsal edge but slightly convex and not much sloping; posterior extremity very obtusely redge-shaped, the dorsal edge near the 
great ligament retuse but afterwards convex; beaks eroded; flexure obsolete; inside pink witl a darker ray or stain on either side; primary tecth two in each valve, a simple and a bicuspiclate, which are alternately inserted.

Icy Cape.

166. Teluiva Columbiexsis (pl. lxv. f. 246.) Manley, Zool. Proc 1844, p.z/.

T. testâ ellipticâ aut oblongo-cllipticî, compressiusculâ, subtenui, lævigatâ, extus intusque albidâ, epiclemide tenuissimâ fulvocincreâ indutî; margine ventrali medio convexiusculo, utrinque arcuato; dorsali utrinque convexo, anticè paulo, posticè satis declivi; latere antico longiore, rotundato; extremitate posticî acuminatî; flexurâ costâque umbonali subobsoletis; ligamento prominulo; dentibus minimis.

Elliptic or elongated-elliptic, fragile, subinequivalve, rather compressed, whitish, covered by a very thin opalescent palc drab epidermis, quite smooth; ventral edge arcuated, ascending posteriorly; anterior side much the longer, its extremity rounded and somerhat attenuated, its dorsal edge convex and scarcely sloping; posterior end acuminated, hinder dorsal edge at first hollowed out for the slightly prominent ligament, then very convex and considerably sloping; flexure and umbonal ridge all but obsolete; inside white, teeth minute.

Monte Christi, TTest Columbia.

Its more compressed valves and minute teeth will distinguish it from the few species which are allied to it in outline. The hingemargin is very short and rather brond.

167. Teluna rufescens ${ }^{\dagger}$ (pl. lxiii. f. 213.) Chemnitz, vol. vi. f. 97. (malè); Dillw. D. Cat. p. S5 ; T. operculata, Gmel. 32:35 ; Wood, Gen. Conch. p. 165. t. 42. f. 1 ; Lam. no. 13; Sow. Gen. Shells ; Hanl. Des. Cat. p. 62. t. 4. f. 37 ; Knorr. vol.vi. t. 12. f.1.

T. testâ oblongâ, inæquivalvi, inæquilaterali, solidâ, subnitidâ, rubro-roseâ (intus saturatius fucatâ), sublævigatâ, lineis obsoletis radiantibus plerumque notatâ; alterâ ralvulâ convexî, alterâ complanatâ; margine ventrali medio subrecto, utrinquuc (presertion posticè) sursum acclinato; dorsali antico convexo, et vix declivi; dorsali postico subdeclivi, prope ligamentum magnum prominensque retuso, deinde magis minusve convexo; latere antico paululum breviore, rotundato; postico attenuato obtusissimè acuminato; costâ umbonali latâ, obtusâ ; flexurâ subobsoletâ.

Oblong, inequivalve, rather strong, scarcely glossy, within and

$+$

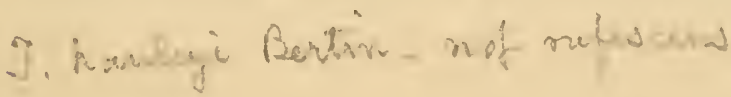


without of a lighter or darker reddish rose-colour, nearly smooth, often with obsolete radiating lines, covered when fresh with a very thin epilermis; one valve convex, the other flat; ventral edge nearly straight or subretuse in the middle, rising at the extremities and particularly posteriorly; anterior side rather the shorter, its extremity rounded, its dorsal edge convex but scarcely sloping; posterior side very obtusely acuminated, the dorsal edge at first retuse and little sloping, then moderately sloping and convex; fold broad and obtuse; flexure nearly obsolcte; ligament large.

Tumbez, Peru; soft sandy mud, five fathoms (Cuning).

168. Tellisa nitida (pl. lix. f. 101.) Poli, Test. Sic. vol. i. t. 15. f. 2, 3, 4; Lam. no. 2S ; Philip. En. Moll. Sic. vol. i. p. 27 ; Hanl. Des. Cat. p. 64. sup. t. 14. f. 4.

T. testâ oblongâ, valdè compressî, æquilaterali, satis solidâ, nitidâ, pallidè carneâ aut fulvâ ; concentricè striatâ, striis tenuissimis, confertis, sed alterâ in valvulâ posticè magis remotis alterâque in valvulâ posticè obsoletis; margine ventrali medio subrecto ; dorsali anticè convexo et subdeclivi, posticè declivi et subrecto ; latere antico rotundato, postico cuneiformi ; flexurâ nullâ.

Oblong, much compressed, equilateral or nearly so, tolerably strong, very glossy, pale flesh-coloured or fulvous, within of a deeper hue, with fine regular and close concentric strix, which at the posterior end of one valve are quite obsolete, and in the other are there replaced by stronger, more distant, and subimbricated ones; ventral edge nearly straight in the middle; anterior side rounded, its dorsal edge convex, and but moderately sloping; hinder side wedge-shaped, ligamental edge nearly straight; no flexure.

Mediterranean.

169. Teluiva Souleyeti (pl. lix. f. 111.) Hanley, Zool. Proc. 1844.

T. testâ oblongâ, tenuiusculâ, convexo-depressâ, extus intusque albidâ, lærigatâ; margine ventrali convexiusculo; dorsalianticè convexiusculo et subdeclivi, posticè recto aut subretuso et valdè declivi ; flexurâ costâque umbonali distinctis ; latere antico longiore, rotundato ; extremitate posticâ subrostratâ; ligamento infosso; natibus acutis.

Oblong, tolerably convex, nearly equilateral, but rather longer in front, of a rather dull white, not very thick, and quite smooth; the ventral edge more or less convex ; the flexure as well as the umbonal ridge quite distinct ; dorsal edge moderately convex and scarcely sloping in front, nearly straight or slightly retusc belind; anterior 
extremity rounded, posterior somewhat beaked; beaks acute ; ligament sunken ; inside white.

San. Nicolas, Zebu.

In the young, there is a slight appearance of rudimentary lateral teeth.

170. Teldixa micans (pl. lix. f. 106.) Manley, Zool. Proc. 1844.

T. testâ ovato-oblongâ, tenui, compressiusculâ, subinæquilaterali, nitidissimâ, pellucidâ, nivế ; striis paucis remotis subobsoletis concentricis, etiamque in adultis, striis subobliquis remotis, anticè oruatâ; margine ventrali anticè obliquè arcuato, posticè subrecto; dorsali anticè vix declivi et convexiusculo, posticè dechivi subretuso et angulum obtusum cum margine postico subincurvato formante; latere postico breviore, cuneiformi ; extremitate anticâ obtusè rotundatâ; flexurâ obsoletâ.

Ovate-oblong, thin, rather compressed, slightly inequilateral, extremely glossy, pellucid, snow-white, with a few indistinct and rather distant concentric striæ in front, which are crossed in adult specimens by very slightly oblique and distant ones; ventral edge obliquely rounded anteriorly, and straightish behind; anterior side slightly the longer, obtusely rounded, its dorsal edge scarcely sloping; hinder extremity wedge-shaped, the ligamental edge subretuse near the moderately projecting ligament, and forming a very obtuse angle with the slightly incurved posterior edge; flexure obsolete.

Catbalonga, Isle of Samar.

Bias, Isle of Negros.

171. Telinna Miles (pl.lxii. f.1SS.) Ilanley,Zool.Proc.1844.

T. testâ T. cuspidi affini sed oblongâ, rostratâ, compressiore; margine antico dorsali vix paululum declivi; ventrali convexo; valvulâ alterâ lineis elevatis concentricis undique striatî.

Like T. cuspis but oblong, beaked, and more compressed; front dorsal edge scarcely at all sloping; ventral edge convex; one valve nearly smooth, the other with regular fine elevated concentric striæ.

Hab.? (Mus. Metcalfe.)

172. Telliva cuspis (pl. lix. f. 125.) ILanley, Zool. Proc. 1844.

T. testî ovatâ, solidiusculâ, convexî, nitidiusculâ, roscâ, anticì et infernè substriatî; margine ventrali arcuato; dorsali utrinque subdeclivi, anticè convexo, posticè recto aut subretuso; flexurû costâque umbonali distinctis; latere antico paululum longiore, rotundato; postico subacuminato, subrostrato ; liganento infosso. 
Ovate, moderately strong, convex, rather glossy, deep rose-colour, substriated in front and towards the lower margin; ventral edge arcuated; dorsal but slightly sloping on either side, convex in front, straight or subretuse behind; fold and flexure perceptible; anterior side slightly the longer, rounded; posterior subacuminated, and somewhat beaked; ligament sunken.

Hab. ? (Mus. Cuming, Metcalfe.)

173. Teldisa scalpellum (pl. lix. f. 116.) Hanley, Zool. Proc. 1844.

T. testâ oblongâ, tenuissimâ, compressâ, nitidissimâ, valdè inæquilaterali, saturatius roseâ, pellucidâ, sublærvigatâ ; margine ventrali recto aut subrecto; dorsali antico paululum declivi, subrecto; latere postico brevi, obtusè subcumeiformi ; extremitate lateris antici longioris, rotundatâ; ligamento parro, prominulo; flexurâ obsoletâ.

Oblong, very thin and pellucid, very inequilateral compressed, nearly smooth or concentrically substriated, of a very glossy deep rose-colour; ventral edge more or less straight; front side produced, rounded at its extremity, its dorsal edge nearly straight and very little sloping ; hinder side obtusely wedge-shaped; ligament small and prominent; flexure almost entirely obsolete.

Isle of Zebu. 1944 .

174. Tellixa exdulata (pl. lix. f. 107.) Hanley, Zool. Proc.

T. testâ oblongâ, tenuissimâ, compressâ, impolitâ et valdè inæquilatcrali, intus extusque albidâ, subobliquè et concentricè undulatî ; margine ventrali convexo ; dorsali anticè subrecto et vix declivi, posticè incurvato satisque declivi; latere postico brevi, attenuato, rostrato, ad extremitatem biangulato; flexurâ costâque umbonali distinctis; natibus acutis ; ligamento infosso.

Oblong, very thin, compressed, very inequilateral, whitish both within and without, not glossy, with oblique undulations which become concentric near the short attenuated and beaked posterior extremity, of which the tip is acute and biangulated ; ventral edge convex; dorsal anteriorly straightish and scarcely sloping, posteriorly incurved and moderately sloping; anterior side produced, its extremity obtusely rounded; fold and flexure perceptible; ligament sunken; beaks acute.

St. Elena, West Columbia.

175. Telina cygrus (pl. lix. f. 122.) Manley, Zool. Proc. 184.4 . 
T. testî ovatî aut ovato-oblongî, solidiusculî,, subæquilaterali, convexî, niticlì, candidâ, concentricè substriatî; margine ventrali convexiusculo; dorsali anticè subrecto et paululum declivi, posticè recto et valdè declivi; extremitate anticî rotumdato-obtusî́; latere postico cunciforni, subrostrato; llexurâ ventrali distinctî́ ; ligàmento infosso; superficie internâ candillâ, submargaritaceî.

Ovate or ovate-oblong, tolerably firm, nearly equilateral, convex, glossy, white, concentrieally substriated; ventral margin slightly convex; dorsal nearly straight and very slightly sloping in front; quite straight and much sloping behind; anterior end obtusely rounded; posterior side wedge-shaped, and subrostrated; llexure distinct; ligament sunken; outsile white and somewhat pearly.

Bias, Isle of Negros, Philippincs.

176. Teluiva ala (pl.1x. f. 137,146.) Manley, Zool. Proc.1S44.

T. testâ ovatâ, solicliusculî, subinæquivalvi, subæquilaterali, nitidâ, convexinsculâ, cxtus intusque albidâ, radio brevi pallidè aurantio in adultis utriuque oruatî, concentricè substriat $\hat{\imath}$; margine ventrali magis minusque convexo ; dorsali auticè convexo et, subdeclivi, posticè declivi et prope nates subretuso; latere antico rotundato, longiore; postico angulato, subrostrato; flexurî costâque tumbonali conspicuis; ligamento infosso; cardine dentibus primariis parvis, et nommunquam dente laterali antico rudimentali, instructo.

Var. ovato-trigonî, solidĥ, lævi ant sublævigatâ, convexâ, nequaquam rostrat $\hat{i}$; flexurâ costîque umbonali subinconspicuis.

Ovate, tolerably solid, very slightly inequivalve, nearly equilateral, rather convex, of a silky gloss, concentrically substriated, whitish within and without, with (in adult specimens) a short pale orange streak radiating on either side from the beaks; ventral eilge nore or less convex ; anterior side rather the longer, rounded at its extremity, its dorsal cdge convex, and not greatly sloping; posterior side angulated and subrostrated, its dorsal edge retuse near the beaks, and decidedly sloping; fold and flexure conspicuous; ligament rather sunken; prinary teeth small, sometincs a rudimentary anterior lateral one

Var. Ovate-triangular, solid, conrex, nearly or quite smooth, not at all beaked, the orange rays clearly visible; fold and tlexure by no means conspicuous.

Ceylon.

177. Teldina xymphalis (pl. lxii. f. 196.) Lam. no. 50 ; Hanl. Des. Cat. p. 70. 
'T. testâ ovatî aut obovatî, magis minusve ventricoŝt, solidiusculâ, subnitillâ, sublævigatâ, subæcquilaterali, extus intusque albidâ, lineis obsoletis pallidioribus subradiatâ, epidermide pertenui lutescente indutâ; margine ventrali anticè arcuato, posticè sursum acclinato; dorsali anticè prope nates acutas subrecto deindeque arcuato et subdeclivi, posticè subretuso et valdè declivi; latere antico longiore, rotundato ; postico attenuato, angulato, et paululum subrostrato ; flexurâ costâque umbonali satis conspicuis ; ligamento prominulo; dentibus minimis.

Ovate or obovate, more or less ventricose, not very strong, rather glossy, nearly equilateral, whitish both within and withont, covered by a very thin yellowish ash-coloured epidermis, nearly smooth being merely wrinkled by the lines of growth, peculiarly marked with obsolete radiating lines; ventral edge arcuated in front and rising behind; anterior side rather the longer, its extremity rounded, its dorsal edge at first nearly straight and then arched and moderately sloping; posterior side attenuated, angulated, and very slightly beaked; fold and flexure tolerably distinct; ligament short and slightly prominent; teeth very small.

Gambia.

In typical examples there is a slight groove-like depression behind the fold, which does not exist in the next species.

178 Teluina Cayennensis (pl. lxii. f. 190.) Psammobia C. Lam. no. 11; Hanl. Des. Cat. p. 58. sup. t. 11. f. 48; Deles. Rec. t. 5. f. 7 ; 'T. constricta, Plil., Ab. und Bes. Conch. part 3. t. 5 . f. 5 ; T. intastriata, Say, Jour. Ac. Nat. Sc. Philad.

T. testâ ovali-trigonâ, solidâ aut solidiusculâ, magis minusve ventricosâ, subinæquivalvi, subinæquilaterali, nitidiusculâ, extus intusque albidâ, epiclermide cinerascente indutâ, sublævigatâ ; margine ventrali convexiusculo; dorsali anticè convexo et subdeclivi, posticè subrecto et declivi; latere antico paulo longiore, rotundato; postico cuneiformi; natibus rectè ineurvatis; ligamento promimulo, satis magno; flexurâ costâque umbonali satis conspicuis; dentibus haud parvis.

Triangularly-oval, more or less solid and ventricose, slightly inequivalve and inequilateral, scarcely glossy, nearly smooth, whitish within and without, covered by a very thin ashy epidermis; ventral edge slightly convex; dorsal convex and moderately sloping in front, straightish (never incurved) and strongly sloping behind; front side rounded, rather the longer; linder side wedge-shaped; beaks incurved; ligament little prominent, and as well as the teeth, of a moderate size; foll and flexure tolerably distinet. 
Closely resembling the last, of which it is possibly a varicty, but is more triangular, and not so distinctly marked with radiating lines.

Guiana, Mexico, Wlorida.

179. Telunda alba (pl. lxii. f. 193.) Quoy and Gaim., Voy. Astrol. Zool. vol. iii. p. 500 . t. S1. f. 1, 2, 3 .

T. testâ subovatâ, solidiusculâ, subcompressâ, subpellucidî, nitidiusculâ, extus intusque albâ, sublævigatâ ; margine ventrali convexo et posticè sursum acelinato; dorsali anticè arcuato et vix subdeclivi, posticè elongato declivi et subrecto; latere antico lato, multum breviore, rotundato ; postico attenuato, obtnsè cunciformi ; ligamento infosso; costâ umbonali et flexurâ ventrali inconspicuis ; natibus subacutis; dentibus bificlis, subvalidis, simplicibus subobsoletis.

Subovate, tolerably strong, rather flat, semi-transparent, nearly sinooth, somewhat glossy, white, one of the valves with obsolete concentric strix; the ventral edge convex and ascending posteriorly; anterior side broad, and distinctly the shorter, rounded at its extremity, arcuated and but little sloping at its dorsal margin; the posterior side obtusely cuneiform, its tip attenuated and obtusely angulated, its dorsal edge elongated scarcely convex and obliquely sloping; beaks rather prominent; ligament sunken; umbonal ridge not conspicuous; the bifid tecth rather strong, the simple nearly rudimentary.

In all the specimens I have seen, there are two or three obsolete radiating folds at ths anterior extremity.

Australia.

1S0. Tellina proxima (pl. lxvi. f. 264. and lix. f. 115.) Brown in Zoology to Beechey, p. 154. t. 44. f. 4 ; Phil. Ab. und Bes. Conch. part 9. pl. 5. f. 4 ; T'. sordida, Conthony, Bostou Jouru. Nat. Hist. vol. ii. p. 59. t. 3. f. 11 ; Sanguinolaria sordida, Gould, Invert. Massachusetts, p. 67 ; Macroma tenera, Leach, Appendix Ross. Voyage.

T. testâ obovali, tenuiusculâ, valdè inæquilaterali, conrexâ aut convexinsculî, impolitâ, extus albidâ, intus candidâ, epidermicle cinerascente fugaci indutî, concentricè obsoletè et subimbrication striolatî ; margine ventrali magis minusve convexo ; dorsali anticè arcuato et paulo declivi, posticè recto et valdè declivi; latere postico brevi, et infernè subangulato ; extremitate posticâ rotundatâ ; natibus plerumque erosis; ligamento maggno, prominente; costâ umbonali subobsoletâ; dentium altero iıı utrîque valvulâ bifurcato.

Oboval, thimish, fragile, very incquilateral, more or less con- 
vex, dull whitish (internally pure white), eovered by a thin ashcoloured fugacious epidermis ; ventral margin more or less convex; front dorsal edge arehed and slightly sloping, hinder one straight and greatly sloping; posterior side short, subangulated below; anterior extremity rounded; beaks usually eroded; ligament large and prominent; fold almost obsolete; one of the teeth bifurcate (when the hinge is perfect, which is rarely the case) in each valve.

Boston, (Gould); Arctic Ocean.

181. Teluina calcarea (pl. lxii. f. 183.) Chemnitz, vol. vi. p. 140. f. 136 ; Dillwyn D. Cat. p. 93 ; Hanl. Des. Cat. p.46. t.4. f. 43 ; 'T. sordida, Phil. Ab. und Bes. Coneh. part 9. t. 5. f. 6.

T. testâ ovatâ aut subovatâ, solidiusculâ, subinæquivalvi, convexiuseulâ, inæquilaterali, extus intusque albidâ, epidermide cineraseente indutâ, sublævigatâ; margine ventrali satis eonvexo, posticè acelinato; dorsali anticè convexo et subdeclivi, posticè declivi et subrecto ; latere antico longiore, ad extremitatem rotundato; postico obtusè cuneiformi ; natibus aeutis, prominentibus; costâ umbonali satis distinetâ; flexurâ ventrali subinconspicuâ; ligamento magno, prominulo ; dentibus parvis.

More or less ovate, moderately firm, very slightly inequivalve, tolerably convex, inequilateral, whitish both within and without, never polished but often slightly glossed, covered with an ashy epidermis, under which it is nearly smooth or merely marked with the lines of growth; ventral edge aseending behind, moderately convex; anterior side the shorter, rounded at its extrenity, its dorsal edge convex and somewhat sloping, but near the aeute and prominent beaks slightly incurved; hinder side obtusely wedgeshaped, the ligamental edge nearly straight; umbonal ridge tolerably evident; the ventral sinus almost obsolete; ligament large and moderately projeeting.

Iceland and Greenland.

182. Tellina nasuta (pl. lxiv. f. 224.) Conrad, Jour. Ae. Nat. Sc. Philad. vol. vii. p. 258 ; Hanl. Des. Cat. p. 71. sup. t. 14. f. 7 .

T. testâ ovato-oblongâ, solidâ, inæquilaterali, convexâ, impolitâ, sublævigatâ, albidâ, epidermide cinerascente plerunque indutâ; margine ventrali medio subretuso; dorsali anticè eonvexo paululumque declivi, posticè elongato reeto et deelivi; latere antieo breviore, rotundato; postico cunciformi; extremitate posticâ subbiangulatâ; natibus obtusis; lunulâ nullâ; flexurâ costâque um- 
bonali conspicuis; ligamento magno et satis prominente; superficie interuâ candidâ ; dentibus satis magnis.

Orate-oblong, solid, inequilateral, convex, dull, whitish, usually covered by an ashy epidermis, nearly smootl, flexuous; ventral margin convex at the sides, but retuse in the middle; anterior side rounded, its dorsal edge convex and but little sloping; posterior side wedge-shaped, its extremity nearly biangulated, its dorsal margin elongated sloping and nearly straight; fold and flexure conspicuous; ligament tolerably large and prominent; beaks obtuse; no lunule; inside white, the teeth of a moderate size.

California.

- 1S3. Tellina edextula (pl. lxv. f. 24.3.) Brod. and Som., Zool. Jour. vol. iv. p. 363; Zool. to Beech. Voy. t. 41. f. 5. and t. 44. f. 6 ; Hanl. Des. Cat. p. 71.

T. testâ obovali-subtrigonâ, solidiusculâ, subventricosâ, subimpolitâ, subinæquilaterali, sordidè albidâ, sublæevigatâ; margine ventrali convexiusculo; dorsali utrinque subdeclivi, anticè convexo, posticè subrecto; latere antico paulo longiore, rotundato; postico obtusè subangulato; flexurâ costâque umbonali subobsoletis ; ligamento magno, prominente; dentibus minimis, sublamellosis.

Var. Abbreviatâ et magis inæquilaterali.

Oboval, subtriangular, tolerably strong, more or less ventricose, of a rather dull dirty white, nearly smooth, more or less inequilateral; ventral edge moderately convex; dorsal not greatly sloping on eitler side, convex in front, straightish and rather short behind; anterior side the longer, rounded at its extremity ; posterior side obtusely subangulated; fold and flexure rather obsolete; ligament large and prominent; inside white; teeth very small, and usually sublamellar.

Var. Shorter and more inequilateral.

Behring's Straits.

- 1S4. Tellina inornata (pl. lix. f. 123.) Hanley, Zool. Proc. 1844. p.int?

T. testâ ovato-oblongâ, subtenui, subventricosâ, impolitâ, subxquilaterali, sordidè albicĥ, epidermide tenui et cinerê̂ indutâ, lævigatâ ; marginis ventralis parte mediâ rectâ aut subretusî̀ ; dorsalis parte anticâ convexiusculâ et paululum declivi, parte posticâ subdeclivi ; extremitate anticâ rotundatâ, posticî attenuato-rotundatâ; flexurâ costâque umbonali obsoletis.

Ovate-oblong, rather thin, subventricose, and nearly equilateral, 
smooth, dull dirty white under a thin ash-coloured epidermis; ventral edge straight or subretuse in the iniddle; dorsal slightly convex and very little sloping in front, moderately sloping behind; frout extremity rounded, the hinder rounded but attenuated; fold and flexure obsolete.

Conception, Chili.

A fossil-like shell, which much resembles an elongated and swollen Edentula.

155. Tellina Balthica (pl. lix. f. 121.) Lin. Sys. 1120 ; Chem. vol. 6. f. 128. Hanl. Des. Cat. p. 72. t. 4. f. 85.

T. testî suborbiculari, subtrigonâ, solidâ, æuuilaterali, subventricosâ, albidâ aut pallidè carnê̂, intus plerumque roseâ, lrevigatâ; margine ventrali arcuato et posticè sursum acclinato; dorsali antico brevi, subdeclivi, et prope nates prominentes subrecto, deindeque convexo; margine ligamentali subrecto aut convexiusculo, ct valdè declivi; latere antico rotundato; extremitate lateris postici angulati rotundatâ; ligamento magno, prominente; flexurầ costîque umbonali obsoletis; dentibus parvis.

Suborbicular, slightly triangular, thick, equilateral, more or less ventricose, white or pale flesh coloured, with the interior usually rosy, smooth, not glossy; ventral edge arcuated, rising behind; front dorsal edge, short and not much sloping, nearly straight adjacent to the prominent beaks, becoming convex subsequently; hinder dorsal edge nearly straight or but slightly convex, much sloping; anterior side rounded; posterior side angulated, but with the tip rounded; ligament large, and prominent; fold and flexure obsolete; teeth small.

Baltic.

Easily distinguished from the allied species, by its more rounded shape, its ventricoseness, and arcuation of its lower edge. T. Fabricii which approaches it in these respeets, is less angulated behind.

186. Teluta fusca (pl. lix. f. 117.) Psammobia fusca, Say, Jour. Ac. Nat. Sc. Philad. 5. p. 220. Sanguinolaria fusca Conrad. Am. Mar. Cone. p. 34. t. 7. f. 1 ; Gould, Inv. Massa. p. 66. f. 42 .

T. testâ obovatâ, solidiusculâ aut subtenui, subæquilaterali, compressâ aut convexiusculâ, subimpolitâ, albidâ, epidermide tenuissimâ cinerascente indutâ, lævigatâ ; margine ventrali maximè et regulariter arcuato; dorsali utrinque subdeclivi, anticè arcuato, posticè subrecto; latere antico rotundato; postico subangulato; 
natibus parvis aentis, prominentibus; tlexurî costîque umbonali obsoletis, ligamento pronimulo; dentibus angustissimis.

Obovate, rather thin, nearly if not quite equilateral, more or less compressed or but slightly convex, searcely at all glossy, whitish under a thin ashy epideruiv, smooth; ventral edge regularly and greatly arcuated; the dorsal edges not much sloping, areherl in front, and nearly straight behind; anterior side rounded, posterior snbangulated; beaks small, acute, and prominent ; ligament rather projecting; fold and flexure obsolete; tecth very narrow.

"Its varieties in size, strength, and eolour, are very great. In muddy bays, they grow to a larger size, and are thick and of a blucish and, sometimes, a rusty colour, and eovered with a firm dark epidermis. In clean sandy localities they are very thin, pure white, or sometimes of a delicate rose or lemon colour, and the epidermis very slight."-Gould.

North America.

157. Thluina incosspicua* (pl. lix. f. 120.) Broderip and Sow., Zool. Jour. vol. 4. p. 363; Zool. to Beech. Voy. t. 4.1. f. 6. Hanl. Des. Cat. p. 72.

T. testâ Solidulæ affini, sed impolitâ et epidermide fusco-cine-

* A species which bears some resemblance to a young Ineonspicua, or Fusca, but which nerertheless is probably distinct, at least judging from the figure, for I have never been able to proeure a specimen of the slicll, is the

Tellina petalum (pl. lxvi. f. 263.) Valexcienses in Zool. to IIumb. and Bonpl. Voy. vol. ii. p. 222. t. 48 . f. 2.

T. testâ suboratâ, temuiuseulâ, fragili, subrequilaterali, compressinsculâ, sublævigatî, supernè subroscâ, infernè albido-lutể, zonis subroscis plerumque ornatâ; margine ventrali satis convexo; dorsali anticè convexo et subdeclivi, posticè convexiuseulo et declivi; latcre antico rotundato; postico subangulato; ligamento parro, brevi; dentibus lateralibus mullis.

Subovate, thimnish, fragile, nearly inequilateral, rather compressed, nearly smootl, merely marked with the stria of growth, somewliat rosy near the beaks, beeoming pale yellowish with rosaceous zones towards the rentral edge, which is but modcrately convex; front dorsal edge convex and not much sloping, linder one but slightly eonvex and decidedly sloping; anterior cxtrenuity rounded; posterior side subangulated; ligament short and small; tecth small, no lateral ones.

Aeupuleo. 
rascente indutâ; latere antico breviore; postico haud acuminato; ligamento permagno; natibus et umbonibus plerumque erosis.

Very like Solidula, but the front side is the shorter one, and the posterior extremity is not at all acuminated. The surface is not glossy, is usually eroded near the beaks, and covered with an ashybrown epidermis near the ventral margin, which is regularly subarcuated. The ligament is very large and prominent.

Arctic Ocean.

183. Tellina Fabricur (pl. lix. f. 112.) Manley; Venus fragilis, Otho Fabr., Faun. Groen. p. 413.

T. testâ suborbiculari, solidâ, æquilaterali, convexâ aut subventricosâ, impolitâ, extus intusque albidâ, epidermide cinerascente indutâ, concentricè subrugulosâ; margine ventrali magis minusve arcuato; dorsali utrimque couvexiusculo, antici subdeclivi, posticè declivi; latere antico rotundato; postico vix etiam obtusissimè subangulato; natibus erosis; ligamento permagno, prominente; tiexurẩ obsoletâ; dentibus minimis.

Suborbicular, solid, equilateral, convex or subventricose, dull white, covered by an ashy epidermis, concentrically wrinkled by the lines of growth; ventral margin more or less arcuated; dorsal edges moderately convex, rather sloping in front, decidedly so behind; anterior side rounded, posterior scarcely at all angulated; beaks croded; ligament large, and prominent; flexure obsolete; teeth very small.

There being already a $\mathrm{T}$. fragilis, I am compelled to alter the orginal specific appellation of the shell.

Northern Seas.

199. Tellina solidula (pl. lix. f. 109, 110.) Pultney, Cat. Dorset. p. 29 ; Mont. Test. Brit. p. 63 ; Maton, Lin. Tr. 8 ; Wood, Gen. Con. 193. t. 46. f. 2 ; Lam. no. 51 ; Hanl. Des. Cat. p. 70. t. 4. f. S4; T. zonata, Dillw. D. Cat. p. 100 ; Psammobia solidula, Turton, Biv. Brit. p.95. t. S. f. 2; T. Balthica, Phil. En. Moll. Sic. vol. i. p. 28 ; T. rubra, Da Cost. Brit. Conch. t. 12. f. 14.

T. testâ rotundato-ovatâ, solidâ, subæquilaterali, convexâ aut subventricosî, magis minusve nitidâ, lævigatâ, albidâ, luteâ, aurantiâ aut roseî; margine ventrali anticè arcuato, posticè sursum acclinato; dorsali anticè arcuato et subdcclivi, posticè declivi et vix convexinsculo; latere autico paululum longiore, rotundato; postico acuminato; natibus acutis, prominentibus ; costâ umbonali obsoletâ; ligamento magno prominente; dentibus angustissimis et sæpe obsoletis. 
Rounded-ovate, solid, subequilateral, convex or subventriose, more or less glossy, smooth or with a few ridger's of growth, rery variable in colouring, being white ycllow oranges or rosy ; ventrial edge arcuated in frout, and rising behind so as to form a sharp angle with the slightly convex and moderately sloping ligamental margin; anterior side very slightly the longer and rounded; its dorsal edge arched and moderately sloping ; liganent promincut ; fold obsolete; beaks rather prominent and acute; tecth extremely narrow, and usnally obsolete.

Britain; Europe ; Senegal.

190. Tellina inus (pl. lx. f. 145.) IIanley, Zool Proc. 1844.

T. testâ ovatâ ant obovatâ, (rassî̀ (in adultis), subventricosî, subxquilaterali, impolitâ, extus intusque sordiclè albidâ; concentricè rugosâ, rugis interruptis, minutis, confertissimis, eleratis; margine ventrali magis minusve arenato; dorsali anticè convexo ct subdeclivi, posticè convexiusculo elongato declivi; latere intico paululum breviore, rotundato; postico inferuè angulato; lnnulâ (in adultis) parvâ, profundâ; ligamento infosso; costâ runbonali subobsoletâ ; dentibus satis maguis.

Ovate or obovate, solid, coarsc, subventricose, subequilateral, dull dirty white both within and without, the surface roughened by minute concentrically arranged but unconnected elevated wrinkles (reminding one of those upon Rrigosa but on a much smaller scale), which lowever are usually (except in portions) abraded; front dorsal edge convex after passing the small but distinct linmle; ligamental edge not greatly convex, and decidecily sloping so as to form an angle with the more or less arehed ventral margin ; beaks inclining to the rounded extremity of the slorter anterior side; ligannent sunken but distinct; a large bifid and a simple scarcely rudimentary tooth in one valve, two rather strong cliverging obtuse ones in the other.

Guinea? Mus. Cuming and Tralton.

191. Tellisa Fragitis (pl. lvi. 1. 14. and lx. İ. 149.) Lim. Syst. 1117 ; Chem. vol. vi. f. S4; Philip. Mol. Sic. p. 2S; Poli. Test. Sic. t. 15. f. 22, 24; Petricola ochrolcuca, Lam., no. 2 ; Payr. Cat. Cors. t. 1. f. 9, ]0; IIanl. Des. Cat. p. 52. sup. t. 1. f. 6 ; Psammobia fragilis, Turt. Biv. Brit. p. ss. t. 7. f. 11, 12.

T. testâ ovato-trigonâ, solicliusculî, subjecllucillâ, valılè imequilaterali, satis tumidâ, subimpolitî, albidâ ant palliclè croccâ, ad umbones flavescente aut croccû, striis remotinsculis elevatis concentricè asperâ; margine rentrali convexo, posticè sursum acclinato; 
dorsali utrinque satis declivi, anticè convexo, posticè prope nates subretuso deindeque convexiusculo; latere antico rotundato, breviore; postico obtusè acuminato et paululum subrostrato ; natibus obtusis; flexurâ costâque umbonali obsoletis; superficie internâ plerumque croceâ; dentibus satis magnis.

Var. Magis elongatâ, tumidâ; striis lamellosis; margine ventrali minus convexo; extremitate posticâ obtusè biangulatî.

Ovate-trigonal, moderately solid, slightly pellucid, very inequilateral, rather tumid; almost devoid of glossiness, whitish with a tinge of yellow or saffron colour (which sometimes but rarely pervades the entire surface) upon the umbones; rough with concentrie elevated rather distant strix; ventral edge convex; dorsal slightly retuse on either side of the obtuse beaks, and then convex and rather sloping in front, scarcely convex but decidedly sloping behind; anterior side short and rounded; posterior obtusely acuminater and very slightly subrostrated; fold and flexure obsolete; inside usually of a saffron colour ; teeth rather large, two diverging ones in one valve, a recurved one in the other.

Var. Elongated and not at all triangular, tumid; the strixe lamellar; ventral edge scarcely at all convex ; linder end obtusely biangulated.

Scarcely a Tellina, but with the teeth and general cliaracters of so many usually included in that genus, that I know not how to separate it. From the figure in Delessert, the Psammolcea Tarentina of Lamarck is probably a variety of this shell.

Britain, Europe.

192. Teluna Guivaica (pl. lix. f. 130.) Chemnitz, vol. xi. p. 348. f. 1651, 1652, 1653 ; Dillw. Des. Cat. p. 69 ; T. polygona, Gmel.; Lam. no. 43.

T. testâ ovatâ, solidâ, ventricosî, impolitâ, inæquilaterali, extus intusque albidâ, lineis rudioribus subremotis elevatis concentriè striatâ; margine ventrali magis minusve convexo; dorsali posticè subdeclivi ct subrecto, anticè magis declivi et subincurvato; latere antico brevi, rotundato ; latere postico rotundato-angulato aut obte sissinè cmeiformi, extremitate ejus semper rotundatî; costî umbonali subinconspicuâ; lunulâ distinctâ ; ligamento infosso ; dentibus magnis.

Ovate, solid, ventricose, dull, inequilateral, within and withont whitish, ronghened by coarse raised concentric and rather distant striae; ventral edge more or less convex; dorsal edge straightish and not much sloping behind, more sloping and somewhat incorved in front; anterior side short and rounded; posterior somewhat 
angulated below, or very obtusely wedgc-shaped, the tip always rounded; fold not very distinct; ligament sunken; it distinct short lunule; teeth very large.

Guinea.

This is probably the Abildgaardiana of Spengler.

193. Temina polygova (pl. lxii. f. 159.) Chemnitz, vol. vi. p. 91. f. 77 ; Dillw. Des. Cat. p. 77 ; Hanl. Des. Cat. p. 69. t. 3. f. 11 ; T. multangula, Gmel., 3230; Lam. no. 42.

T. testà ovato-oblongâ, solidlâ, veutricosî, inacquilatcrali, impolitî, cxtus intusque albidâ, lineis elevatis confertis concentricè striatî, anticè breviore, posticè subcunciformi; margine ventrali subrecto; dorsali anticè paululum declivi, posticè longo snbrecto declivi ; cxtrenitate anticâ obtusâ ; posticâ attenuatâ et liangulutû ; Hexurâ costâque umbonali perspicuis ; ligamento subinfosso; dentibus magnis.

Ovate-oblong, solid, ventricose, inequilateral, not glossy, whitish within and without, roughened by coarse crowded concentric raised stria, shorter in front, somewhat wedge-shaped behind; rentrul edge straightish, but rendered wavy by two extremcly obsolete and subcentral radiating ridges; anterior extremity obtuse, dorsil edge short and scarcely at all sloping; posterior tip narrow and biangulated, the ligamental margin long straightish and sloping; fold and flexure evident; teeth large.

Guinea.

194. Teluina Bruguieri (pl. lxii. f. 192.) Hanley, Zool. Proc. ] 814; Enc. Mèth. t. 231. f. 2.

T. testâ rotundato-trigonâ, solidâ, subæquilatcrali, convexî, impolitâ, cxtus intusque albidâ, sublacrigatâ, (ant striis exilibus obsoletis radiantibus strias concentricas tenuissimas decussantibus); margine ventrali convexo aut subarcuato; dorsali posticè clevatiore valdè declivi et paululum convexo, anticè arcuato et declivi; extrenitate anticâ obtusâ ; posticâ rotundatâ ; natibus prominentibus, et anticè incumbentibus; flexurâ costîque umbonali obsolctis; ligamento infosso; lunulâ parvâ ; dentibus maximis.

Suborbicular, subtriangular, solid, nearly equilateral, convex, white within and without, dull, nearly smooth, when closely examined some of the adult specimens present the appearance of a most minute decussation, cansed by the intersection of delicate obsolete radiating lines and very finc concentric stria, which latter are chiefly apparent near the convex or subarenated ventral margin; posterior dorsal edge abruptly sloping, slightly convex, and 
more elevated than the arcuated and moderately sloping anterior; front extremity broad and rounded, linder one obtuse; ligament sunken ; fold and flexure obsolete; beaks prominent and inclining forward; teeth extremely large.

Isle of Panay, Philippines (Cuming).

195. Teldina alta (pl. lxii. f. 200.) Conrad, Jour. Ac. N.S. Philarl. vol. vï. p. 25S; Hanl. Des. Cat. p. 71.

T. testâ obovali, subventricosâ, crassiusculâ, subinæquilaterali, impolitâ, concentricè et confertim rugosâ, extus intusque albilâ; margine ventrali subrecto; dorsali utringue paululum declivi, anticè convexo, posticè recto; latere antico longiore, rotundato; extremitate posticâ obtusè biangulatâ; costâ umbonali latâ, planullatî; nlatibus rectè incurvatis; ligamento infosso; dentibus angustis.

Oboval, slightly ventricose, thickish, slightly inequilateral, dull white, with crowded concentric wrinkles; ventral elge straightish ; dorsal little sloping on either side, convex in front, rectilinear behind; anterior side rather the longer, rounded at its extremity; posterior side obtusely biangulated; umbonal ridge broad but flattened ; beaks directly incurver ; ligament sunken ; inside white ; the teeth narrow; the hinge margin broad.

California.

196. Thluiva ephippium (pl. lxv. f. 244.) Spengler, loc. cit.

T. testâ Lacunosæe simillimâ, sed valdè inæquivalvi et planè inæquilaterali ; costâ umbonali angustissimâ, carinatâ.

Closely resembling Lacunosa, but decidedly inequivalve and inequilateral; the umbonal ridge narrow and carinated in the flatter valve, replaced by a linear indentation in the other.

East Indies (Spengler).

197. Tellina lacunosa (pl. lxv. f. 252.) Chem., vol. iv. p. 92. f. 78 ; Lam. no. 39 ; Enc. Mèth. t. 290. f. 14; Hanl. Des. Cat. p. 69. t. 3. f. 12 ; 'T. papyracea, Gmel.

T. testî obovali, ventricosâ, subinæquivalvi, subæquilaterali, tenuiusculâ, subpellucidâ, extus intusque candidâ, sublievigatâ, medio contorto-lacunosî; margine ventrali subrecto sed contorto; dorsali antico subarcuato; ligamentali subdeclivi, subrecto ; latere antico lato, rotundato; postico lato, obtuso; natibus prominentibus, incurvatis; ligamento subinfosso; costâ umbonali latâ, obtusî. 
Var. Testâ crassiore; parte superiore lateris postici partem inferiorem superante.

Oboval, rather thin, very slightly inequivalve, nearly inequilateral, ventricose, somewhat pellucid, white, nearly smooth or with delicate concentric wrinkles, which are chiefly apparent near the rounded anterior extremity; ventral edge nearly straight (as to convexity), but much twisted, owing to the concavity in front of the obtuse but prominent umbonal slope in one of the values; dorsal edge scarcely sloping, arcuated in front, straightish belind; extremity of the hinder side (which is slightly the shorter) very obtusely biangulated; ligament rather sunken; beaks broad and directly, incurved; teeth small.

Var. Thicker and coarser; a broader space from the umbonal ridge to the posterior end, which latter projects at its upper extremity.

Guinea.

195. Tellisa spectabilis (pl. lxv. f. 254.) Hanley, Zool. Proc. 1514.

T. testâ ovato-trapeziformi, subtenui, maximè inæquilaterali, ventricosâ, impolitâ, extus intusque albidâ; concentricè striatî, striis elevatis, tenuibus, rugosis; margine ventrali pauluhum convexo; dorsali anticè convexo et declivi, posticè recto aut subincurvato et maximè declivi; extremitate lateris antici longioris obtusî; extremitate posticâ truncato-cunciformi, obtusè biangulatî; flexurâ costâque umbonali conspicuis; ligamento magno, haud prominente; dentibus minimis.

Ovate, subtrapeziform, not solid, extremely inequilateral, ventricose, dull, white both internally and exterually, with fine raised concentric wrinkles, which are rather distant near the beaks, but become closer towards the but little convex ventral margin ; anterior side produced, its dorsal edge convex and sloping (in the young it is at first almost parallel with the ventral); its extremity obtuse or more rarely rounded; posterior side extremely short, its extremity truncato-cuneiform and obtuscly biangulated, the ligamental edge abruptly sloping and straight or slightly incurved; fold and flexure prominent, the former subcarinated in the young; ligament large but not projecting; teeth minute.

Bay of Manilla and Isle of Siquijor.

199. Teluna Donbei (pl. lxii. f. 192, and pl. lxiv. f. 222.) Hanley, Zool. Proc. 1844. Dermetreyi corr, in indexe.

T. testî obovatî aut ovali, subinæquivalvi, magis minusve so- 
lidâ, subventricosî, subimpolitî, sublævigatâ, extus intusque albidî, umbonibus aurantio-roseis; margine ventrali subrecto ant panlılum convexo ; dorsali antico vix declivi et prope nates prominulas subretuso, deinde magis minusve convexo; margine ligamentali declivi, subrecto; extremitate anticâ rotundatâ; latere postico breviore, obtusè cuneiformi ; flexurâ subobsoletâ, (rarius distinctâ); ligamento infosso.

Var. Testâ majore, impolitâ, opacî, concentricè subrugosî, umbonibus haud erubescentibus; flexurâ costâque umbonali distinetis.

Varying in form from oborate to oval, more or less solid, rather ventricose, rarely at all glossy, whitish with the umbones reddish crimson, nearly smooth, (in full grown individuals with a few concentric strix near the scarcely convex ventral margin, whose flexure is rarely distinct); anterior side the longer, sometimes greatly, at others scarcely so, its dorsal edge for about half its length from the rather prominent beaks somewhat retuse and nearly parallel to the lower edge, thence declining in a convex slope to the rounded termination; hinder extremity more or less obtusely wedge-shaped, the ligamental edge sloping strongly, and being more or less straight ; ligament sunken ; the inner disk red; one umbone projecting beyond the other.

Var. Larger, dull, opaque, the umbones not coloured, the surface somewhat wrinkled concentrically ; fold and flexure distinct.

Panama, the variety from Tumbez.

200. Tellina angulata (pl. lxv. f. 250.) Chemnitz, vol. vi. p. 89. f. 74, 75 ; Wood, Gen. Conch. p. 146. t. 43. f. 1; Schroet. Einl. vol. ii. t. 7. f. 8 ; Lutraria Tellinoides, Lam.; Deles. t.3. f. 5 ; Hanl. Des. Cat. p. 27. sup. t. 11. f. 33.

T. testî subovali, inæquivalvi, solidiusculâ, inæquilaterali, convexâ aut subventricosâ, extus intusque albâ, sublævigatî ; margine ventrali subrecto ant convexiusculo; dorsali utrinque paululum dechivi aut subdeclivi et subrecto, posticè elevatiore, anticè prope nates subineurvato; latere antico obtuso aut rotundato, longiore; extremitate posticâ obtusâ, subattenuatâ, aut obtussimè biangulatâ; natibus prominentibus incurvatis, acutis; costâ umbonali satis distinctâ; ligamento parvo, angusto, infosso ; dentibus obsoletis.

Somewhat oval, inequivalve, tolerably strong, moderately inequilateral, convex or subventricose, white both within and without, nearly smooth; ventral edge straightish or but slightly convex; anterior side the longer, its extremity rounded when the straightish 
dorsal edge (which is slightly incurved near the beaks) is modrrately sloping, when but little sloping obtuse; posterior extrenity very obtusely biangulated, or attenuated and obtuse; beaks acute prominent and incurved; fold tolerably distinct; ligament small narrow and smken; teeth obsolete.

Ceylon and Isle of Negros, Plilippines; (Cuming).

This is not the T. angulata of Limeus, which 1 believe to be a Psammotia.

201. Tellixa gubernaculum (pl. Kiii. f. 1S6.) Janley, Zoo!. Proc. 1544.

T. testâ subovatî, subinæquivalvi, tenui, compressiusculî, læri, extus intusque albidâ, valdè inæquilaterali; margine ventrali convexiusculo, anticè sursum acclinato ; dorsali anticè magis minusve convexo et declivi, posticè recto brevi rt subito declivi; extremitate lateris antici longioris rotundato-attenuatî; cxtremitate posticit brevissimâ, truncato-cunciformi ; flexurầ costâque umbonali obsuletis ; ligamento infosso ; dentibus parvis.

Var. Testâ magis clongatâ; latere postico brerissimo ; marginc dorsali posticè maximè declivi, anticè subrecto.

Suborate, rather inequivalve, thin, somewhat compressed, smooth, whitish, rery inequilateral ; ventral edge moderately convex, sloping uptrards in front; dorsal more or less convex and sloping anteriorly, but short straight and abruptly declining posterivily ; anterior side produced, its extremity attcnuated and rounded; posterior side extremely short and truncato-cuneiform; fold and flexure obsolete; ligament sunken; teeth small.

Var. More elongated ; linder side extremely short; dorsal edge nearly straight in front, most abruptly sloping bchind.

Real Lejos, Central America (Cuming).

202. Teldina truxcata. (pl. Kxii.f. 19S.) Jonas, Ab. und Bes. Concl. part 3. t. 5. f. 2.

T. testâ ovali-subtrigonâ, solidinsculâ, subinæquivalvi, subren-

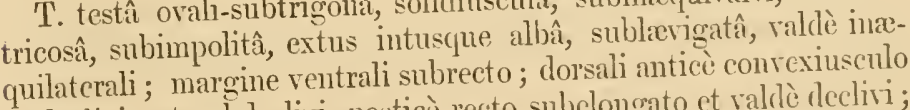
et declivi aut subdeclivi, posticè recto subclongato et valı̀e declivi; latere antico producto, ad extremitatem rotumdato-attemuato; latere postico subcuneiformi, ad cxtremitatem angusto ct subangulato; flexurâ subobsolctî; ligamento magno, infosso; dentibus primariis distinctis.

Oval-subtriangular, tolerably strong, slightly inequivalve, rather rentricose, rather dill white, ncarly smooth, very incquilateral; 
ventral edge nearly straight; anterior side attenuated, produced and rounded, its dorsal edge sloping and tolerably convex; posterior side nearly wedge-shaped, the extremity narrow and subangulated, the dorsal edge straight, rather long in proportion and strongly sloping; flexure almost entirely obsolete; ligament large and s unken; inside white; teeth distinct.

Bay of Manilla (Cuming).

Not unlike Gubernaculum but the hinder side in that species is less wedge-shaped, the tip being broader, and the ligamental edge decidedly shorter.

203. Tellina pellucida (pl. lix. f. 118.) Philippi, Ab und. Bes. Conch. part 3. t. 5. f. 4.

T. testâ ovatâ aut obovatâ, tenui, inæquilaterali, convexâ, nitidâ, extus intusque niveâ, lævigatâ; margine ventrali convexo, posticè sursum acclinato ; dorsali anticè convexo et paulo declivi, posticè convexiusculo et declivi ; extremitate lateris antici longioris rotundlatâ; extremitate posticâ obtusâ aut rotundatâ; natibus acutis, haud prominentibus; ligamento fulvo, infosso; costâ umbonali obsoletâ; dentibus angustis, minimis.

Var. Testâ abbreviatâ; margine dorsali utrinque magis declivi et minus convexo.

More or less ovate, thin, decidedly convex, inequilateral, pure glossy white both within and without, smooth, or with a few lines of growth; anterior sicle the longer, its extremity rounded, its dorsal edge convex and but little sloping; hinder side clearly the shorter, its dorsal elge sloping and but slightly convex, tip obtusely rounded; ventral edge convex (or even subarcuated) and inclining upward posteriorly; ligament yellow and sunken; beaks acute but not prominent; umbonal ridge obsolete; teeth minute.

Var. Abbreviated; the dorsal edges more sloping and less convex.

Bay of Manilla (Cuming).

\section{4 .}

204. Teluina Chinensis (pl.lvi. f. 18.) Hanley, Zool. Proc.

T. testâ ovali, solidiusculâ, convexâ, subinæquilaterali, inıpolitâ, extus intusque candidâ, lrevigatâ ; margine ventrali subrecto ; dorsali anticè convexiusculo et paululum declivi, posticè subrecto satisque declivi ; extremitate posticâ obtusâ ; latere antico longiore, rotundato ; ligamento —? ; costâ umbonali obsoletâ.

Oval, tolerably strong, convex, slightly inequilateral, dull white, smooth; ventral edge nearly straight; anterior side the longer, 
rounded at its extremity, its dorsil edge scarcely at all sloping and moderately convex; postcrior extremity obtuse, the limcler dorsal edge moderately sloping and nearly straight; ligancnt - ? umbonal ridge obsolete; inside white.

China (Mus. Brit.). 1844 .

205. Teluina frigida (pl. lix. f. 119.) Hanley, Zool. Proc.

T. testâ ovali, solicliusculâ, convexâ, inæquilaterali, nitidâ, albidâ (intus candidâ), lævigatâ, utrinque rotundatâ; margine ventrali convexo; dorsali antico subdeclivi, convexo; latere postico planè breviore; natibus inconspicuis; flexurâ costîque umbonali obsoletis; dentibus minimis.

Oval, tolerably strong, convex, inequilateral, glossy, whitish, sinootl, rounded at each extremity; ventral edge convex; front dorsal convex and moderately sloping; posterior side decidedly the shorter; beaks not prominent; fold and flexure obsoletc; teeth minute; inside white.

Kamskatclika.

206. Teluina grandis (pl. lxv. f. 247.) Hanley, Zool. Proc. 1544.pe $18 \%$,

T. testâ ovali, subtrigonâ, solidâ, subinæquivalvi, lævi, convexâ, subimpolitâ, extus intusque albilâ, anticè rotundatâ; margine ventrali convexiusculo; dorsali utrinque declivi, posticè recto aut subrecto, anticè vix convexiusculo; extrenitate lateris antici brevioris obtusâ; flexurâ costâque umbonali subobsoletis; ligamento magno

Subtriangularly oval, solid, slightly inequivalve, convex, smootl, rather of a dull white under an almost imperceptible epidermis, which is only visible near the but little convex ventral margin; anterior side clearly the longer, its extremity rounded, its dorsal edge but little convex and moderately sloping, ligamental edge straight, and strongly sloping; posterior termination obtusc; fold and flexure almost entirely obsolcte; inside white, the linge-plate strong, the teeth of a moderate size.

Tumbez, Peru.

207. Tellina secta (pl. lxv. f. 245, 248.) Conrad, Jour. Ac. N. S. Philad. vol. vii. p. 257. Hanl Des. Cat. p. 67.

T. testâ solidiusculâ, inæquivalvi, nitidî, extus intusque candidâ, lævigatâ; alterâ valvnlâ convexî, alterâ complanatâ ; margine ventrali subarcuato; dorsali utrimque haud multum declivi, 
et prope ligamentum magnum inciso; extremitate anticâ rotundatâ ; costâ umbonali magis minusve conspicuâ; dentibus primariis distinctis; margine cardinali sub ligamento intus incrassato, superficie internâ impolitâ.

Téstá seniore obovali, xequilaterali ; margine dorsali subhorizontali, convexiusculo; latere antico lato ; extremitate posticâ obtusâ; margine postico angulum obtusum cum margine ventrali formante; ligamento maximo.

Testa juniore sicut in seniore, sed ovali, inæquilaterali ; margine dorsali antico subdeclivi; latere antico longiore, attenuato.

Var. Testâ ovali, inæquilaterali, margine dorsali antico subdeclivi; latere antico longiore, plerumque ad extremitatem attenuato ; extremitate posticâ angulatâ; margine ventrali posticè subincurvato ct magis sursum acelinato.

Inequivalve, tolerably strong, smooth, glossy, rounded in front; one valve convex, the other flattened; ventral margin subarcuated; dorsal edges not greatly sloping, near the large ligament (under which the hinge margin is internally thickened) with an incision; unbonal ridge more or less conspicuous; teeth distinct.

Aclult. Oboval, equilateral, hinge-margin subhorizontal and slightly convex; anterior side broad; hinder extremity obtuse; posterior edge forming one obtuse angle with the ventral; ligament very large.

Young. Resembling the adult, but oval and inequilateral; the front dorsal edge moderately sloping; anterior side the longer, attentated at its termination.

Tar. Oval, inequilateral ; front dorsal edge moderately sloping; anterior side the longer, and generally attenuated at its extremity; posterior end angulated, the hinder ventral edge being somewhat incurved and sloping upward.

California.

To this section belong, likewise, the T. lateralis and brerifions of Say, which, however, I am unable to identify; and as the species lave not been recognised by any subsequent conchologists, and are unknown even to the naturalists of the United States, I cannot, consequently, add to descriptions which will not exactly apply to any Tellens I am acquainted with.

"Teldina lateralis, Say, Journ. Ac. Nat. Sci. Philad.

Transversely suborate, subequilateral; posterior (anterior) mar- 
gin regularly rounded, anterior (posterior) margin beaked, the rostrum turned to the left and slightly gaping, ligament slope straight; basal margin regularly arcuated, a little contracted near the beak ; valres whitish, often tinged with ferruginous, with small concentric wrinkles and slight waves; within white, a little sculptured by the extenal wares; no lateral teeth, two cardinal in one valve, and one with another hardly elerated filiform one in the other.

South coast of the United States."

Telemsa Bretifroxs Say, Am. Conch. t. 61. f. 1.

Ovate, thin, fragile, not rerr conrex, white, tinged particularly on the umbo with pale dull fulvous; mith transterse (concentric) slender striæ, and in a particular light obsolete longitudinal (radiating) striæ are visible; beaks much anterior (posterior) to the middle, forming an angle in consequence of the anterior and posterior hinge-margin being rectilinear to a considerable distance, the latter parallel to the base; anterior (posterior) side short and abrupt, rounded at the tip, and with a submarginal undulation; posterior (anterior) side more than as long again as the anterior (posterior), rounded at tip; within much more deeply coloured with fulvous! cardinal teeth, two in the left and one in the right valre; lateral teeth none."

The shell is represented in the drawing as nearly an inch long, of a pale rose-colour (!), and of a subelliptical contour, a shape neither agreeing with the description nor with the further statement that "its outline corresponds with $T$. donacina, but is more convex" (!). I regard it as a rery doubtful and ill-defined species. A single specimen only has been met with by Dr. Rarenel in South Carolina.

The T. lintea of Conrad, which, being described in company with recent shells, I had introduced into my 'Descriptive Catalogue,' I have since ascertained to be fossil. 


\section{TELLINA.}

\section{LIST OF PLATES LVI. TO LXVI.}

Fig.

1. Tel. Guildingii, Sp. 16.

2, 3. - robusta, 56 .

4. - pulchella, 17.

5. - virgulata, 18 .

6. - distorta, 19 .

7. - pudica, 46 .

8. - semen, 51.

9. - casta, 57.

10. - balaustina, 58 .

11. - obliquilineata, 59 .

12. - donacina, 20.

13. - umbonella, 150 .

14. - fragilis, 191.

15. - carnicolor, 75.

16. - bimaculata, 52.

17. - Senegalensis, 68.

18. - Chineusis, 204.

$\left.\begin{array}{l}19,20 . \\ 21,22 .\end{array}\right\}$ - bimaculata, 52 .

23, 24. - ampullacea, 60.

25. - tulipa, 21.

26. - Gouldii, 92.

27. - decora, 120.

28, 29. - flexuosa, 72 .

- 30. - pisiformis, 71 .

31. - Cyrenoidea, 66.

32. - Lucinoides, 53.

33. - nux, 54.

34. - pinguis, 55 .

35,36 . - lineata, 22 .
Fig.

37, 38. Tel. carnaria, Sp. 69. 39. - splendida, 67. Plate LVII.

40. - spinosa, 77.

41. - pumila, 105.

42. - virgo, 118.

43. - crystallina, 89 .

44. - inæqualis, 104.

45. - ostracea, 87.

46, 47. - lineata, 22.

48. - subtruncata, 83 .

49. - mera, var. 101.

50. - Corbuloides, 108.

51. - culter, 107.

52. - felix, 110.

53. - Hiberna, 112.

54. - hilaris, 111.

55, 56. - Philippinarum, 106.

57. - Corbuloides, 108.

58. - inæquistriata, 31.

59. - tenera, 114.

60. - polita, II3.

61. - Cycladiformis, 102.

62. - fabula, 123.

63. - juvenilis, 125.

64. - subrosea, 146.

65. - similis, 119.

96. - Deshayesii, 2.

97. - vestalis, 132.

68. - Valtonis, 116. 
Fig.

69. Tel. truncatula, Sp. 131.

70. - cmarginata, 130.

71. - lux, 126.

\section{Plate LVIII.}

72. - Cumingii, 3.

73. - Cumana,148.

74, 75. - Antonii, 5.

76. - aurora, 153.

77. - verrucosa, 6 .

78. 79. - crucigera, 4.

S0. - inæquistriata, 31.

81, 82. - tenuis, 124 .

83. - formosa, 163.

84. - vernalis, 127.

85. - lilium, 158.

86, 87. - lanceolata, 133.

88. - iridescens, 122.

89. - punicea, 33.

90. - coccinea, 143.

91. - eburnea, 36 .

92. - rhomboides, 162.

93. - rhodon, 144.

94. - ancilla, 160 .

95. - assimilis, 157 .

96,97. - rhomboides, 162.

98. - lucerna, 152.

99. - Burneti, 90.

100. - conspicua, 136.

Plate LIX.

101. - nitida, 168 .

102. - Bodegensis, 161.

103. - lutea, 165.

104. - exilis, 117.

105. - rhodora, 109.

106. - micans, 170.

107. - undulata, 174.

108. - dispar, 164 . rig.

109, 110. Tel. solidula, Sp. 189.

111. - Soulcyeti, 169.

112. - Fabricii, 188.

113,114 . - dispar, 164 .

115. - proxima, v.macroma, 180.

116. - scalpellum, 173.

117. - fusca, 186.

118. - pellucida, 203.

119. - frigida, 205.

120. - inconspicua, 187.

121. - Balthica, 185.

122. - cygnus, 175 .

123. - inornata, 184.

124. - planissima, 140.

125. - cuspis, 172.

126. - obliquilineata, 59 .

127. - decora, 120.

129. - deltoidalis, 62 .

129. - plebeia, 149 .

130. - Guinaica, 192.

Plate LX.

131. - Antonii, 5.

132. - fimbriata, 73.

133. - Owenii, 25.

134. - Psammotella, 129.

135. - asperrima, 9.

136. - insculpta, 128

137. - ala, 176.

139. - sulcata, 10.

139. - perplexa, 86 .

140. - regia, 35 .

141. - acuminata, 139

142. - incarnata, 115.

143. - nobilis, 151 .

144. - sincera, 70 .

145. - irus, 190 .

146. - ala, 176.

147. - ovalis, 142. 
Fig.

148. Tel. staurclla,Sp. 15.

149. - fragilis, 191.

150. - triangularis, 138.

151. - plebeia, 149.

152. - prora, 39.

153. - rubescens, 38 .

154. - punicea, 33.

155. - imbellis, 103.

Plate LXI.

156. - gargadia, 76 .

157. - rostrata, 1.

15s. - Timorensis, 135.

159. - altemata, 37 .

160. - pristis, 84 .

161. - striata, 34 .

$162,163$. - vulsella, 27.

164. - albinella, 29.

165. - pulcherrima, 8.

166. - albinella, 29.

167. - hyalina, 134 .

168. - laceridens, 40.

169. - crassa, 78.

170. - rosea, 30 .

171. - staurclla, 15.

172. - Timorensis, 135.

173. - crassa, 78.

174. - plauata, 99.

175. - striatula, 61 .

176. - laceridens, 40.

177. - plectrum, 79.

Plate LXII.

178. - crucigera, 4.

179. - Brasiliana, 45.

180. - Mars, 94.

181. - gargadia, 76 .

182. - Dombei, 199.

183. - calcarea, 181.
Fig.

184. Tel. decussata, Sp. 74.

185. - Capsoides, 85.

186. - gubernaculum, 201.

187. - lyra, 91.

1ss. - miles, 171.

159. - polygona, 193.

190. - Cayennensis, 178.

191. - plicata, S8.

192. - Bruguieri, 194.

193. - alba, 179.

194. - purpurascens, 141.

-195. - candida, 155.

196. - nymphalis, 177.

197. - planissima, 140.

199. - truncata, 202.

199. - elongata, 156 .

200. - alta, 195 .

\section{Plate LXIII.}

201. - magna, 96,

202. - perna, 28.

203. - sinuosa, 137 .

204. - virgata, 12.

205. - Sowerbii, 47.

206. - princeps, 32 .

207. - interrupta, 11.

20S. - chlorolenca, 49.

209. - Tongana, 42.

210. - - chlorolcuca, 49.

211. - strigosa, 98.

212. - virgata, 12.

213. - rufescens, 167.

214. - jubar, 13.

215. - Pharaonis, 26.

216. - marginalis, 14 .

217. - perma, 28.

218. - Madagascariensis, 41.

219. -- perna, 28. 
Fig.

221, 220. Tel. radiata, Sp. 4 .

\section{Plate LXIV.}

222. - Dombei, 199

223. - Galathea, 154 .

224. - nasuta, 182.

225. - levigata, 50 .

226. - remies, 65 .

227. - lævigata, 50 .

228 . - diseus, 64 .

229. - deltoidalis, 62 .

230. - fausta, 63 .

231. - rastellum, var. 7 .

232. - diseus, 64 .

233. - rugosa, 82.

234. - fausta, 63 .

-235. - scobinata, 80 .

- 236 . - lingua-felis, 81 .

237. - lata, 48 .

238, - rugosa, 42.

\section{Plate LXV.}

239. - magna, 96.

240. - Sol, 97.

241. - elegans, 43.

212. - rastellum, 7 .

243. - edentula, 183.
Fig.

24. Tel. ephippium, s.1. 19».

$2+5$. - sceta, 207.

246. - Columbiensis, 16,6 .

247. - grandis, $201 ;$.

248. - secta, 207.

249. - lutea, 165.

250. - angulata, 200 .

251. - Listeri, 103.

252. - lacunosa, 197.

253. - foliacea, 95 .

254. - spectabilis, 195 .

Plate Lxyi.

- 255. - rubicunda, 93.

256 . - serrata, $\not 4$.

257. - margaritiona, $1+7$

258. - laceridens, var. 40.

259. - donacina, v. Lantivi, 20 .

260. - decora, 120 .

261. - staurella, v. scalaris. 15.

262. - Ondardi, 145 .

263. - petalım, p. 317, note.

264. - proxima, 180 .

-265 . - incaruata, 1].5.

266. - tenta, 159.

267. - iris, 121.

269. - mera, 101.

\section{ALPIIABETICAL INDEX}

acuminata, Sp, 139.

ala, 176 .

alba, 179.

albinella, 29.

alta, 195 .

- alteruata, $3 \%$.

anıullacea, 60 . ancilla, Sp. 160.

imgulata, 200.

- Antonii, 5. i $\therefore$.

assimilis, $1.5 \%$.

asperrima, 9.

aurora, $15 \%$.

balaustina, 58 . 
Balthica, Sp. 185.

- bimaculata, 52.

Bodegensis, 161.

Brasiliana, 45.

Bruguieri, 194.

Burneti, 90.

calcarea, 181.

- candida, 155.

Capsoides, 85,

carnaria, 69.

carnicolor, 75 .

casta, 57.

Cayennensis, 178. W. $\therefore$

Chinensis, 204.

chloroleuca, 49 .

coccinea, 143.

Columbiensis, 166 .

conspicua, 136.

Corbuloides, 108.

erassa, 78.

crucigera, 4 .

crystallina, 89. IV. 2.

culter, 107.

Cumana, 148.

Cumingii, 3 .

cuspis, 172.

Cycladiformis, 102.

cygnus, 175.

Cyrenoidea, 66.

decora, 120.

decussata, 74 .

deltoidalis, 62 .

Deshayesii, 2.

discus, 64 .

dispar, 164.

distorta, 19.

Dombei, 199.

donacina, 20.

eburnca, 36 .
-edentula,Sp. 183.

elegans, 43.

elongata, 156 .

emarginata, 130.

ephippium, 196.

exilis, 117.

Fabricii, 188.

- fabula, 123.

fausta, 63. W.2.

felix, 110.

fimbriata, 73 .

flexuosa, 72.

foliacca, 95 .

formosa, 163.

fragilis, 191.

frigida, 205.

fusca, 186.

Galathæa, 154.

gargadia, 76 .

gelida, 23.

Gouldii, 72 .

grandis, 206.

gubernaculum, 201.

Guildingii, 16.

Guinaica, 192.

Hiberna, 112.

hilaria, 111.

hyalina, 134 .

imbellis, 100.

in:qualis, 104.

inæquistriata, 31.

incarnata, 115.

inconspicua, 187.

inornata, 184.

insculpta, 128.

interrupta, 11. W :

iridescens, 122.

iris, 121. Ni,

irus, 190. 
- jubar, Sp. 13. juvenilis, 125. laceridens, 40 . lacunosa, 197.

- lævigata, 50. ฟ.

lauceolata, 133. lata, 48 .

lilium, 158.

- lingua-felis, 81. lineata, 22. W. 9 .

- Listeri. 103. lucerna, 152 .

Lucinoides, 53.

lutea, 165 .

lux, 126.

lyra, 91 .

- Madagascariensis, 41 . magna, 96 . W. S. margaritiua, 147 . marginalis, 14 .

Mars, 94 .

mera, 101.

micans, 170.

miles, $17 \mathrm{I}$.

$\checkmark$ nasuta, 182.

nitida, 168.

nobilis, 151 .

mux, 54 .

- nymphalis, 177.

obliquilineata, 59.

ostracea, 87.

Oudardi, 145.

ovalis, 142.

Owenii, 25.

pellucida, 203.

pernä, 28.

perplexa, 86 .

petalun, p. 317, notc.

Pharaonius, 26.
Philippinarum, sp. 106.

pinguis, 55.

pisiformis, 71 .

planata, 99.

planissima, 140.

plebeia, 149.

plectrum, 79.

plicata, 88.

polita, 113.

polygona, 193.

princeps, 32.

pristis, 84 .

prora, 39 .

proxima, 180.

Psammotella, 129.

pudica, 46.

pulchella, 17. ․

pulcherrima, 8.

pumila, 105.

punicea, 33 . W.

purpurascens, $1+1$.

radiata, 44.

rastellum, 7.

regia, 35 .

remies, 65 .

rhodon, 144 .

rhodora, 109.

rhomboides, 162.

robusta, 56 .

rosea, 30 .

- rostrata, 1.

rubescens, 38 .

rubicunda, 93.

rufesceus, 167. irs

- rugosa, 82.

scalpellum, 173.

- scobinata, 80.

secta, 207.

semen, 51 . 
Senegalensis, Sp. 68.

serrata, 24.

similis, 119.

sincera, 70.

sinuata, 137.

sol, 97 .

- solidula, 189.

Souleyeti, 169.

Sowerbii, 47.

spectabilis, 198.

spinosa, 77.

splendida, 67.

staurella, 15.

striata, 34 .

striatula, 61 .

strigosa, 98.

subrosca, 146

subtruncata, 83.

sulcata, 10.

tenera, sp. 114. N.9.

tenta, 159.

tenuis, 124.

Timorensis, 135.

Tongana, 42.

triangularis, 138.

truncata, 202.

truncatula, 131.

tulipa, 21.

umbonella, 150 .

undulata, 174.

Valtonis, 116.

vernalis, 127.

verrucosa, 6 .

vestalis, 132.

- virgata, 12.

virgo, 118.

virgulata, 18.

- vulsella, 27.

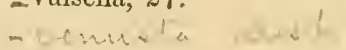




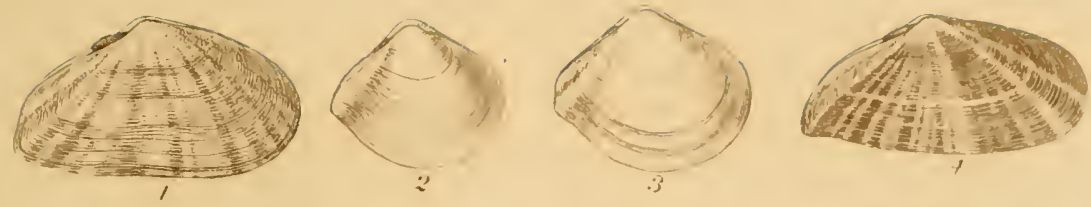

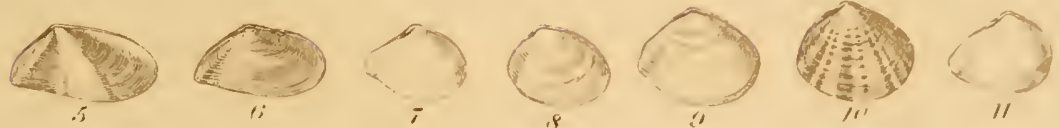
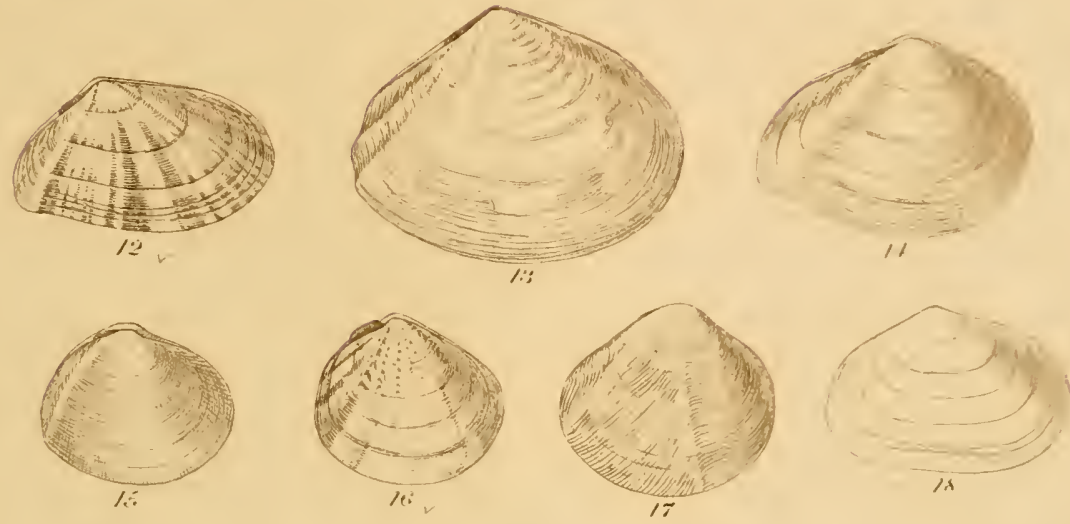

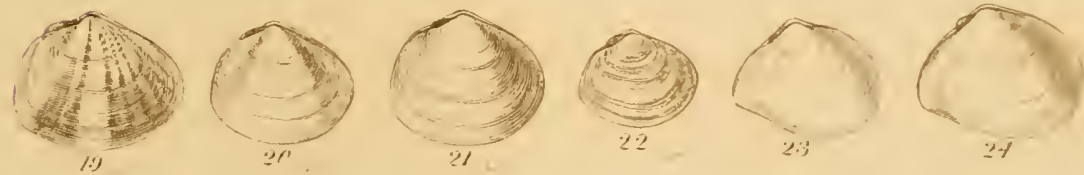
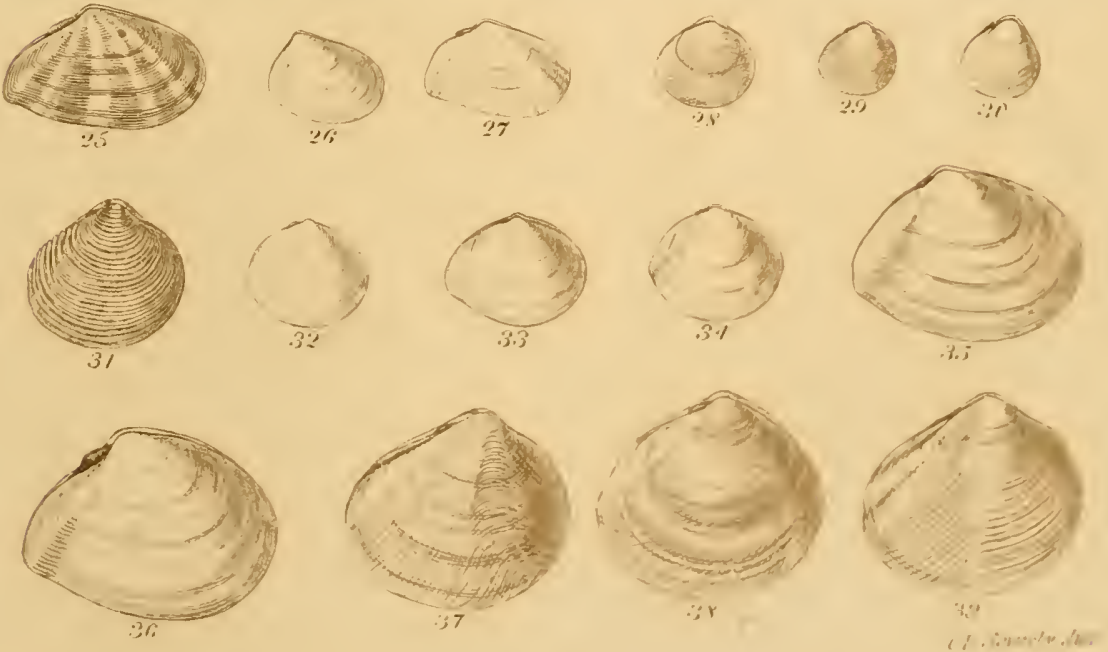


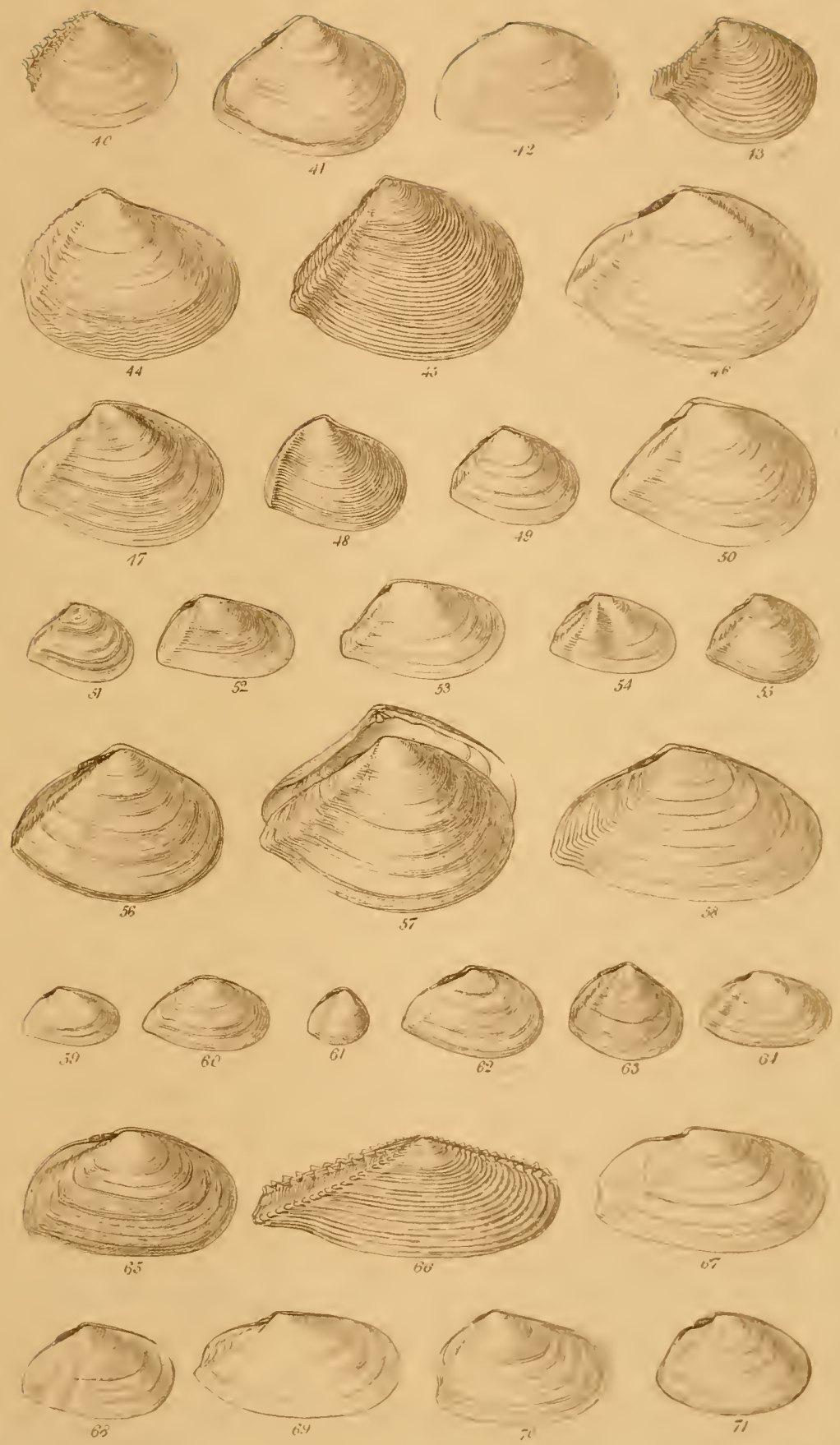

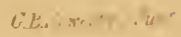



LIIII
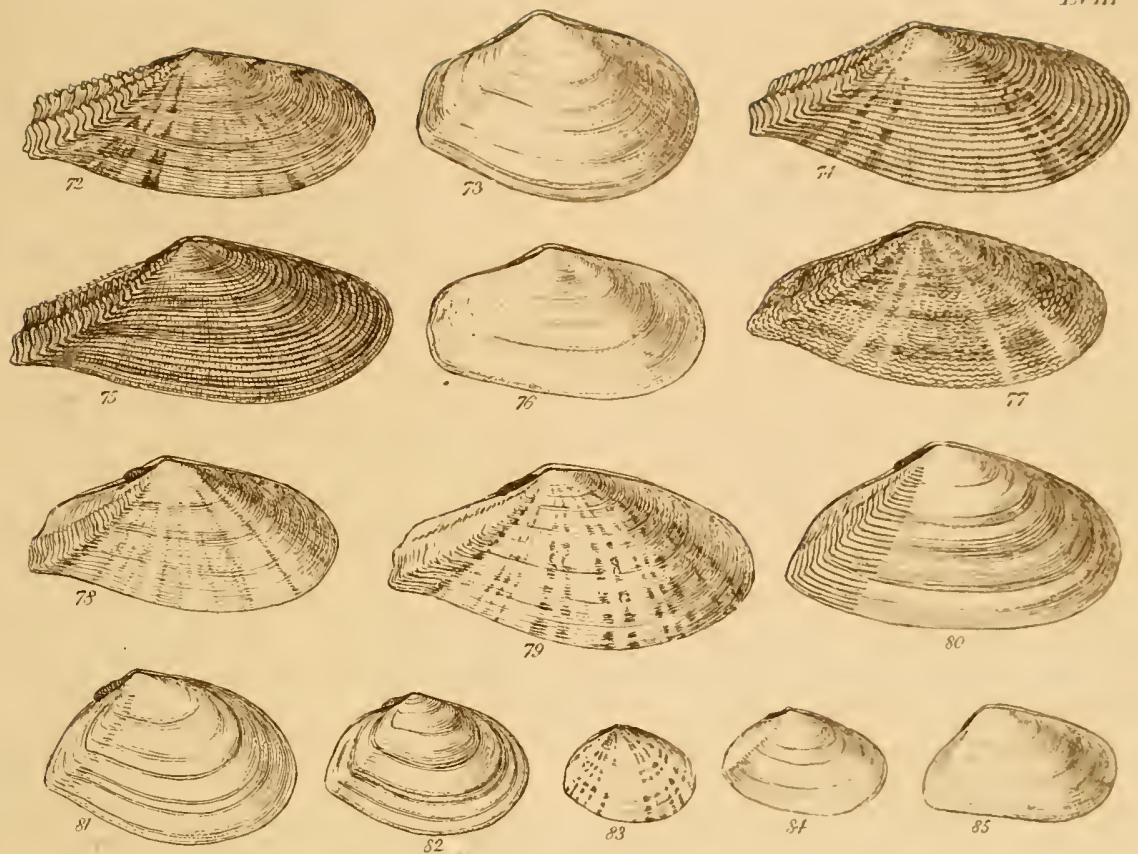

$\left(\frac{13}{25}\right.$
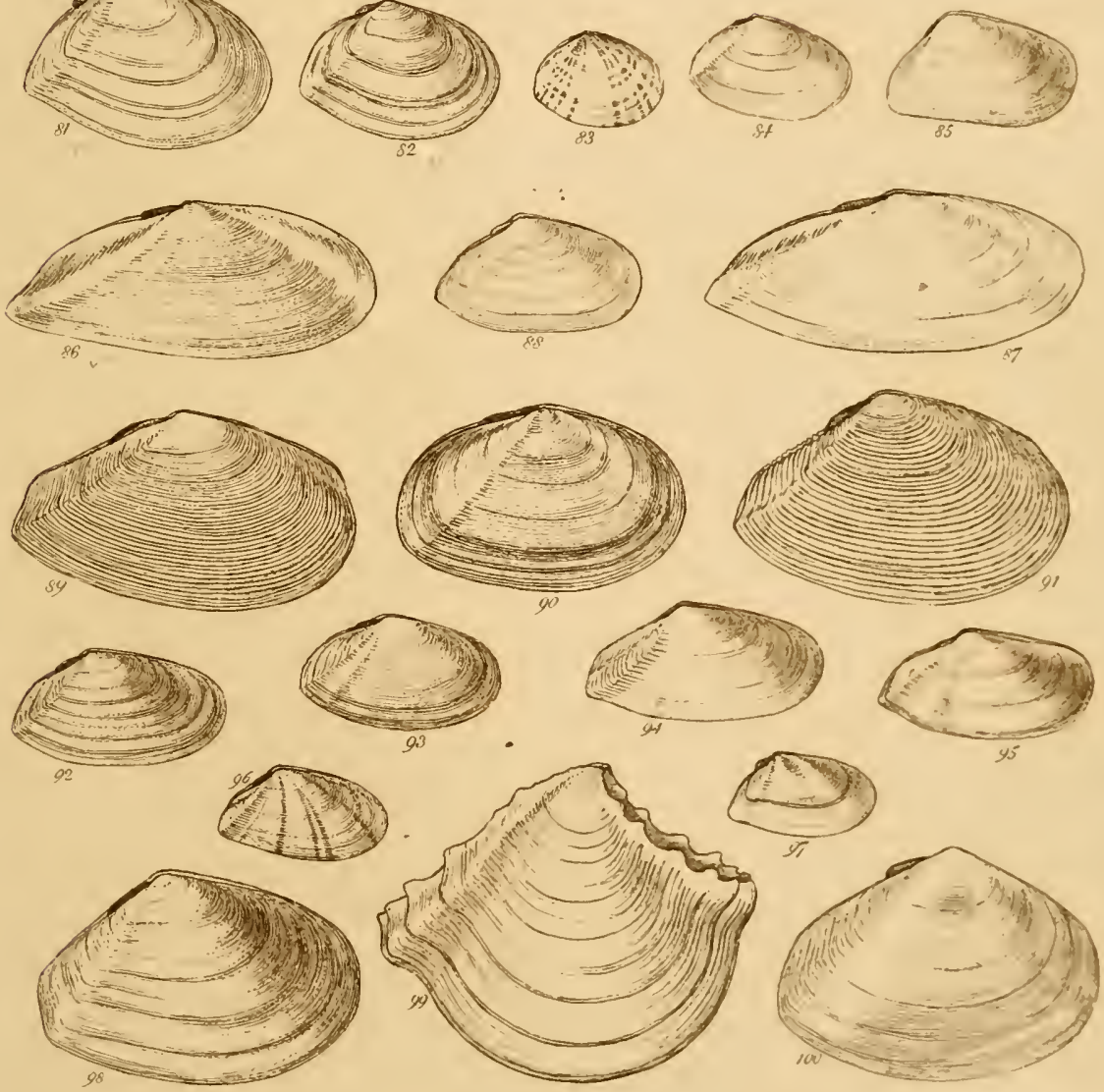


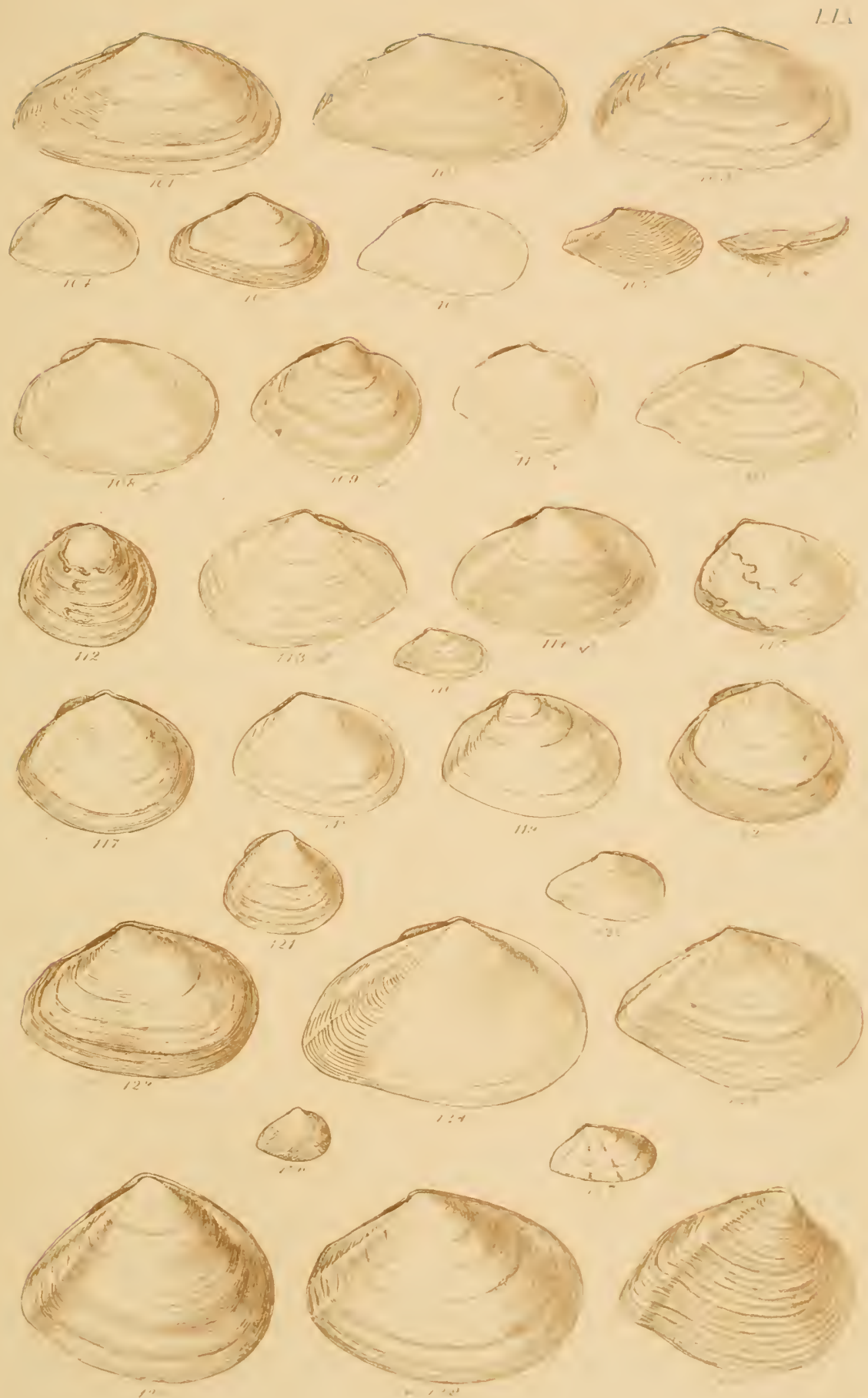



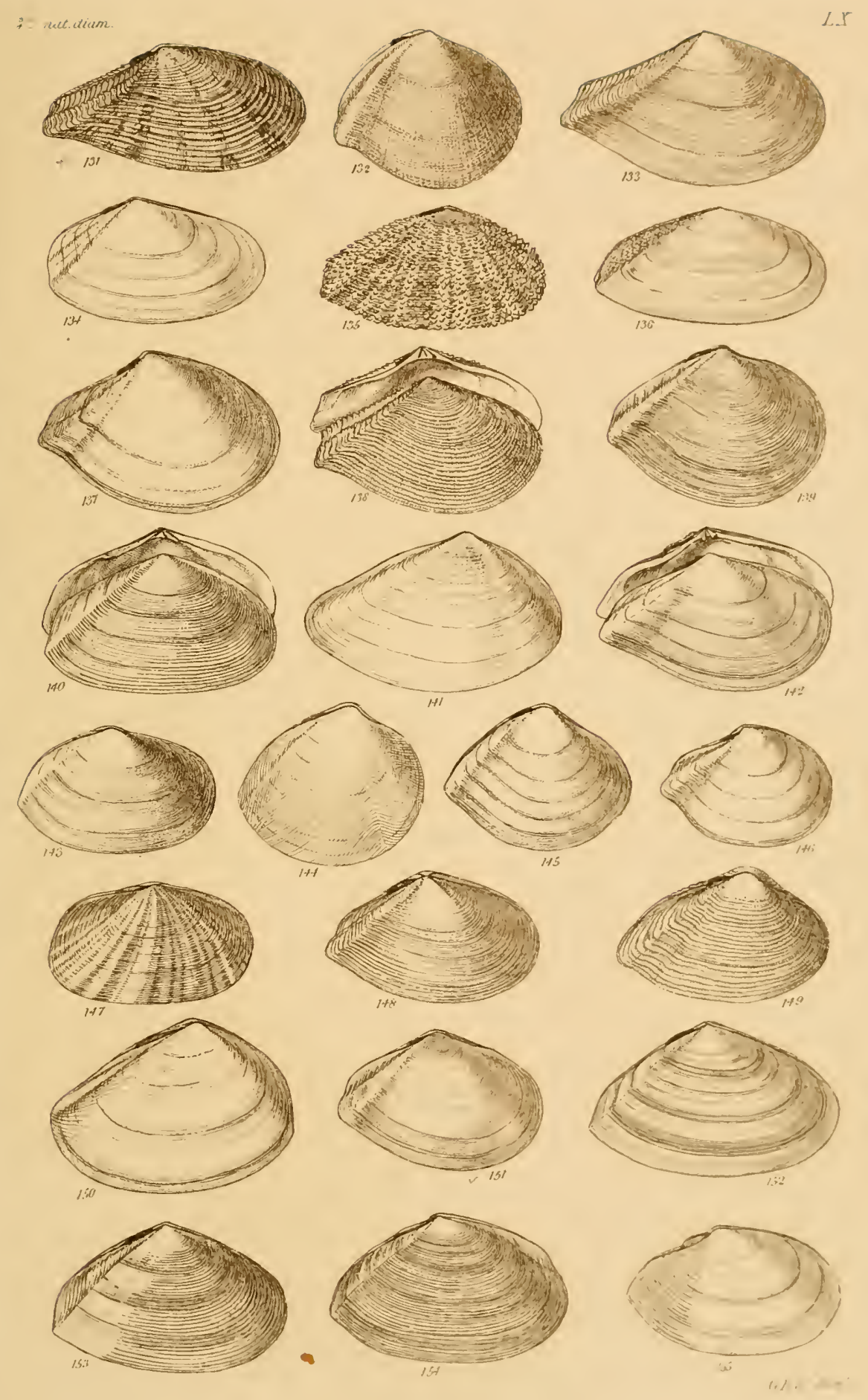





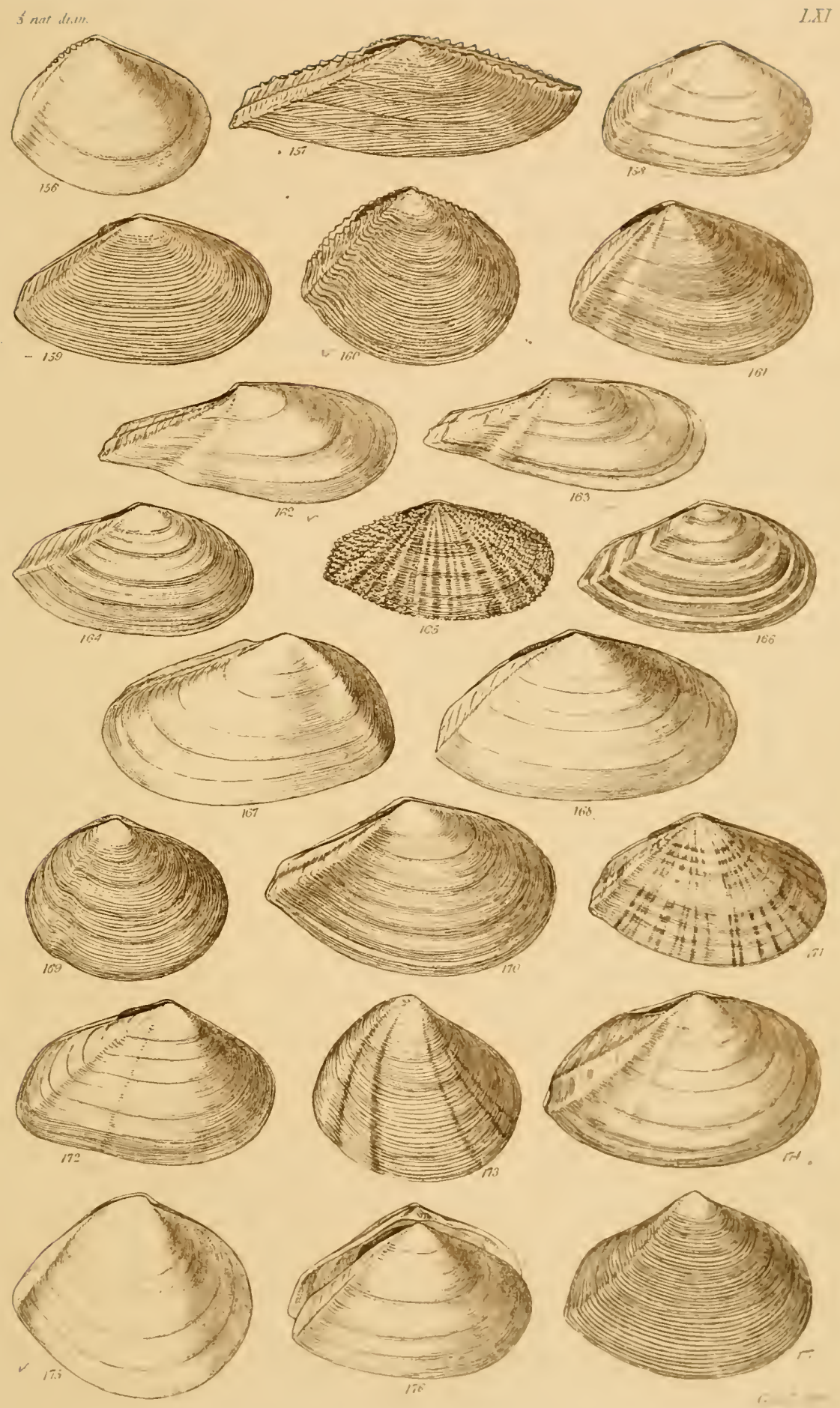





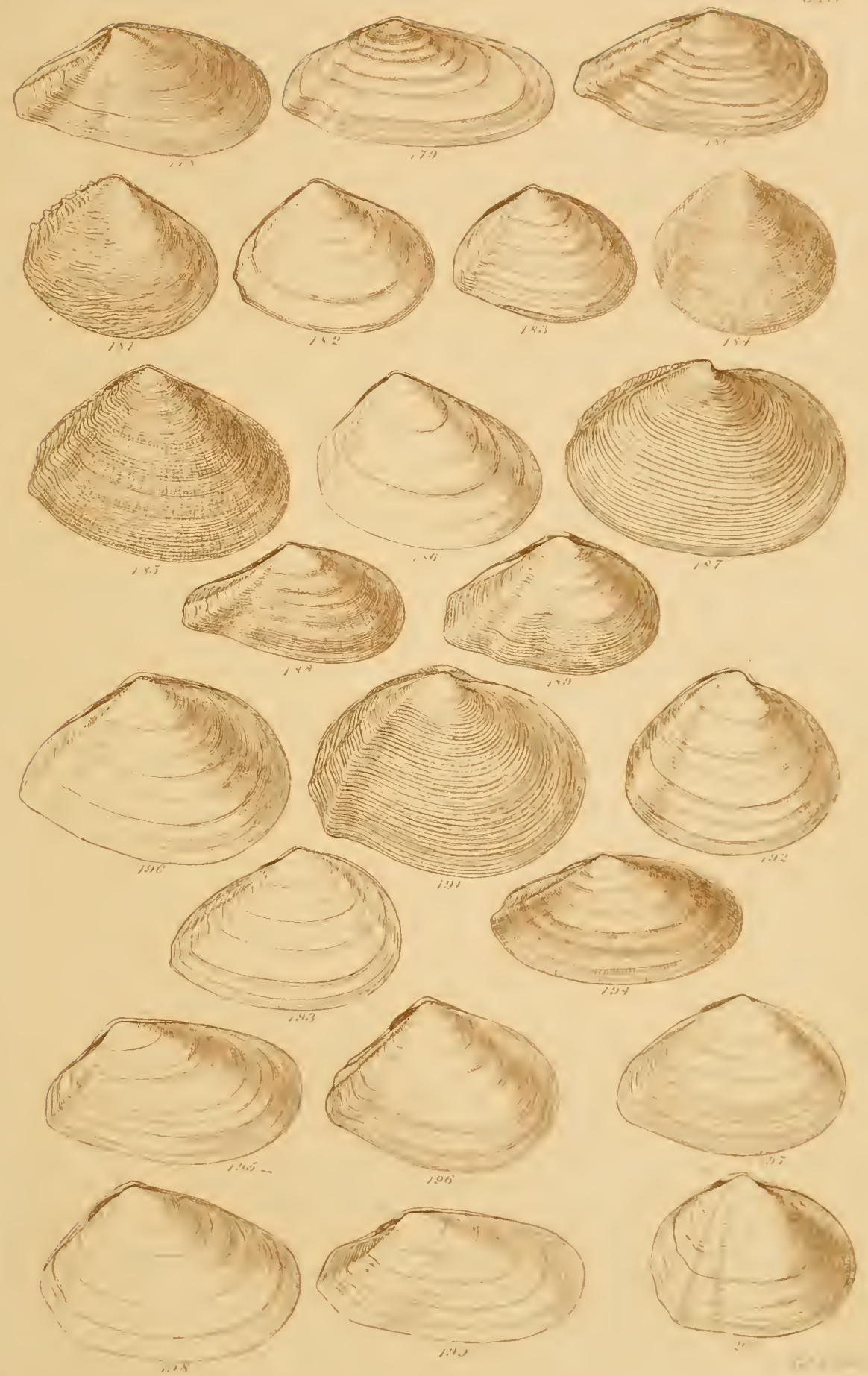





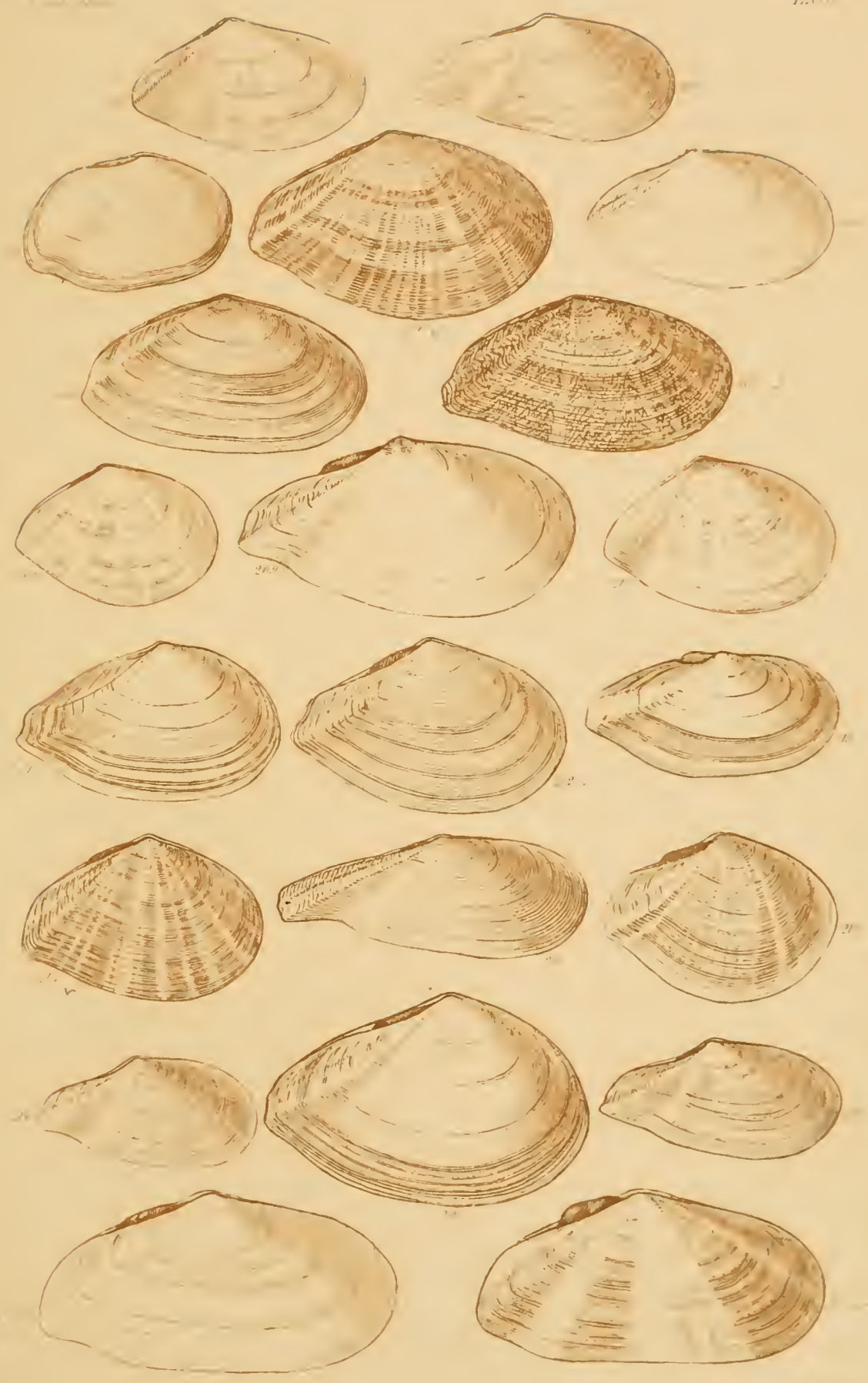





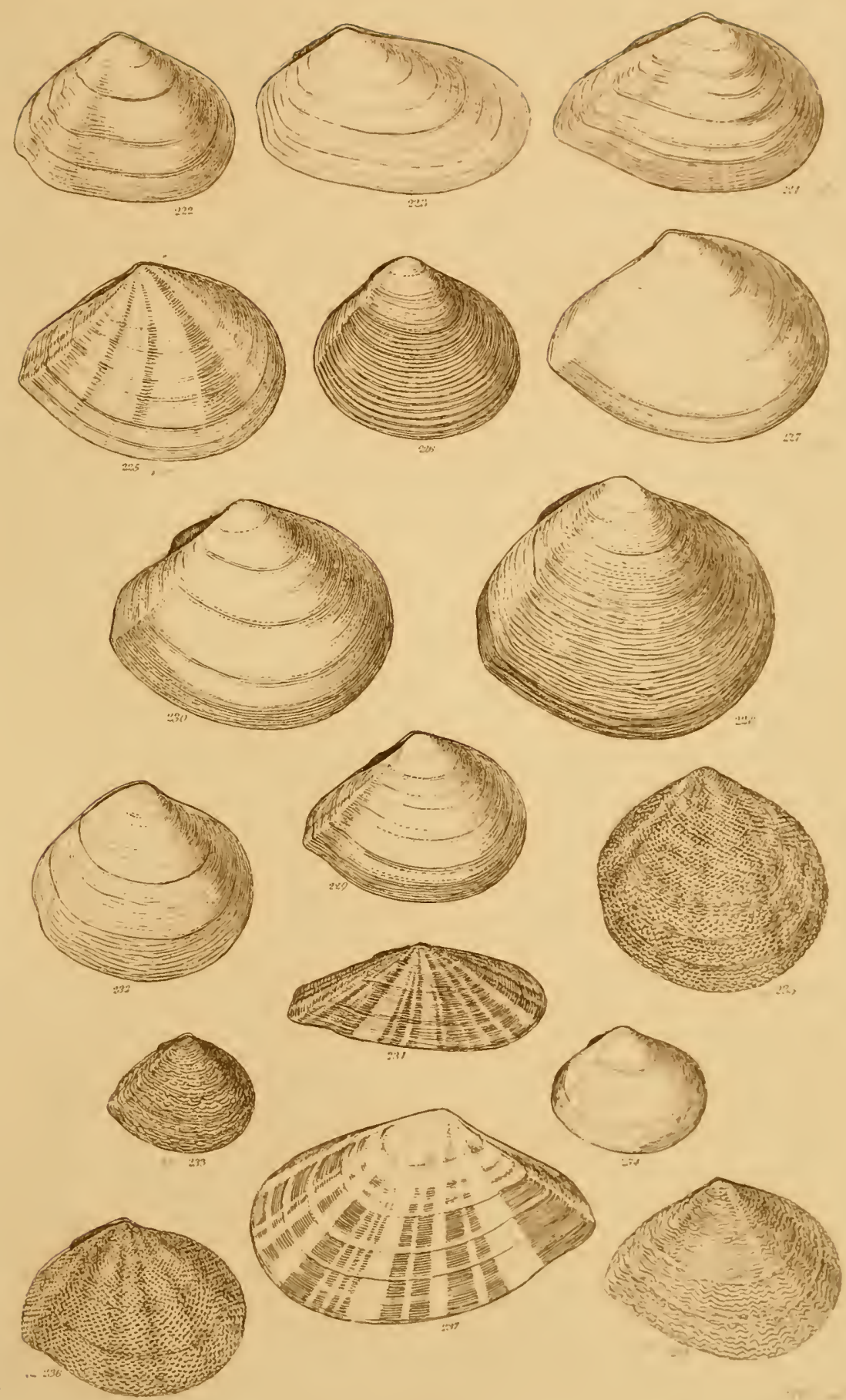





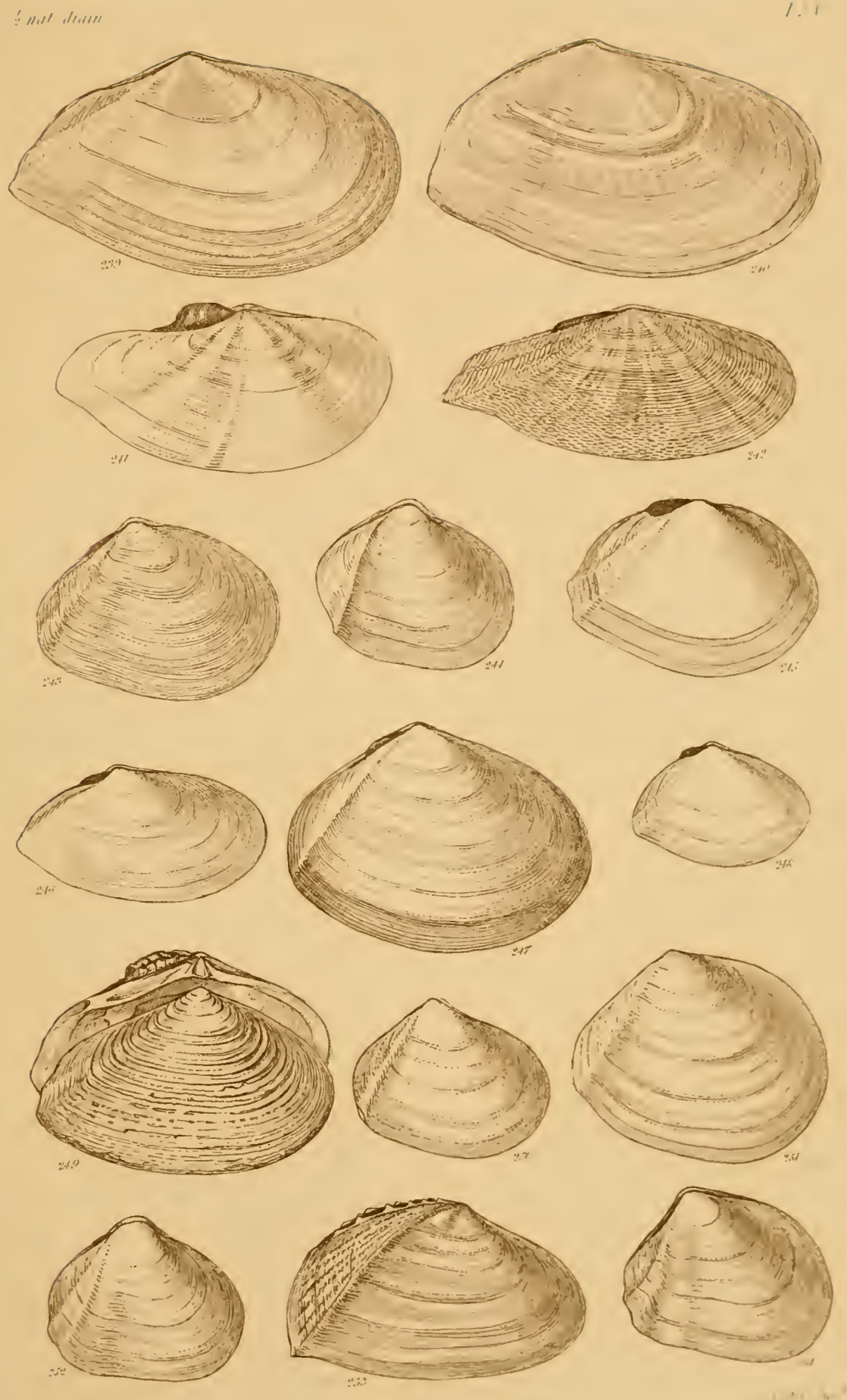





\title{
MONOGRAPH OF THE GENUS
}

\section{LINGULA, Bring.}

\author{
By G. B. Sowerby, F.L.S., etc.
}

Char. Gen. Testa temuis, subæquivalvis, xquilateralis, oratoelongata, depressa, apice subtruucato, basi subacutî, pediculo affixấ. Impressiones musculares in utrâque valvâ quatuor, ad utrumque latus duæ, altera basalis, altera subcentralis.

Shell thin, consisting for the most part of a horny cpiclermis, lined with a small quantity of calcarcous matter within; its general form when the valves are closed is an elongated oval, compressed and much resembling a duck's bill, (whence the specific appellation of the first known species). The two valves are very nearly equal, the dorsal being somewhat thicker and more acuminated at the base. When in a state of rest, the two valves are closed at the edges in all parts. There is neither ligament nor linge, the two valves being held together by the adductor muscles. Muscular impressions several in each valve, arranged in pair's, one pair nearly central, another toward the posterior part, and a third, small and double, close to the posterior apex. The shell is attached by a peduncle which is fixed within the apex of the dorsal valve.

Of recent species seven are here described and figured, more than double that number are known in a fossil state, as characterizing the various secondary and tertiary deposites.

\section{DESCRTP'TIONS.}

1. Lingula anativa (pl. lxvii. f. 1, 2, 3, 9, 10.) Lam.

L. testâ oblongâ, compressâ, longitudinaliter substriatî, apicis L. testâ oblongâ, compressâ, longitudice subtrilobo, valvâ ven-
basisque valvarum latitudine æquali, apice
trali medio intùs longitudinaliter incrassatî.

Shell oblong, compressed, slightly striated longitudinally, equal 
in width at both ends; apex somewhat trilobate; ventral valve longitudinally thickened near the centre within.

Fig. 1 represents the usual variety with its peduncle. Fig. 2, inside of the dorsal valve. Fig. 3, inside of the ventral valve. Fig. 9, a variety of a brown colour, found in sand at low water, at the Island of Siquijor, by Mr. Cuming. Fig. 10, a dark coloured
variety.

From the Indian Ocean and the Molnccas, H. Cuming.

2. Lingula hians (pl. lxvii. f. 4.) Swains. L. testâ elongato-oblongâ, tenuissimâ, angustiori, prope basin
paulatim attenuatâ, convexiusculâ.

Shell of a lengthened oblong form, very thin and rather narrow, slightly attenuated and rather convex toward the base.

Distinguished from $L$. anatina by being much thinner and of a more delicate green colour; it is also slightly and gradually attenuated toward the base; it only gapes at the extremities when the valves are separated from the animal and dried.

3. Lingula Audebardi (pl. lxvii. f. 5.) Brod. Zool. Proc. 1833. p. 100.

L. testâ elongato-oblongâ, glabrâ, pallidè flavâ, viridi transversim pictâ, margine antico rotundato, viridi.

"The rounded anterior edge of this shell is given and the transverse lines of that colour are produced by the progressive increase of the shell which is small and parchment like. In all the dried specimens the thin anterior edge is contracted into a square form, but in its natural state this edge is rounded. A general contraction moreover gives the dried shells a narrower and more ventricose character than they really possess, and the remains of the cilia of the mantle give to their edges a bearded appearance." - Brorl.

Found by Mr. Cuming in hard coarse sand at about half tide, from four to six inches below the surface, at the Island of Punam
in the Bay of Guayaquil.

\section{Lingula Semen (pl. lxvii. f. 11.) Brod. 1. c.}

L. testâ ovato-oblongâ, crassiusculâ, planâ, albidâ, lævissimâ, politâ,

Shell ovate-oblong, thickish, flattened, whitish, very smooth and polished; anterior margin rounded.

"This shell is much firmer than is usual to Lingula, so firm indeed as not to have contracted at all in drying. In size and appearance it bears a near resemblance to a melon seed."-Brod.

Dredged off the Isle of Plata, West Columbia; H. Cuming. 
5. Lingula tumidula (pl. lxvii. f. 7.) Reere, 7ool. Proe. 1841. p. 100.

L. testî tenui, cornet̂, subquadratâ, latâ, rufescente-olivacê̂, radiatim irregulariter striatî, apice subtrilobo.

Broader in proportion than any other known species; it is somewhat narrower toward the base than at the apex, and it is irregularly and somewhat radiately striated from the base to the broad and subtrilobate apex.

New Holland.

Lingula compressa of Reeve is only a badly preserved specimen of this species. Masbate, H. Cuming. p. 100.

6. Lingula ovalis (pl. lxvii. f. 8.) Reeve, Zool. Proc. 18t1.

L. testâ oblongo-ovali, subcompressâ, tenui, anticè rotundatâ.

Distinguished from other species by its regularly oblong-oval shape, both ends being nearly similar.

Sandwich Islands, H. Cuming.

7. Lingula albida (pl. lxvii. f. 6.) Hinds, Moll. Voy. of the Sulphur, p. 71 . t. 12. f. 4 .

L. testâ oblongâ, lævi, complanatâ, anticè truncatâ, ubique albidâ; pediculo brevi, cylindraceo.

"This species is distinguished by its uniform dead white colour, and very short pedicle, which does not exceed half the length of the shelly portion."-Hinds,

Bay of Magdalena, California.

\section{EXPLANATION OF PLATE LXVII.}

1. 2. 3. Lingula anatina, Sp. 1.

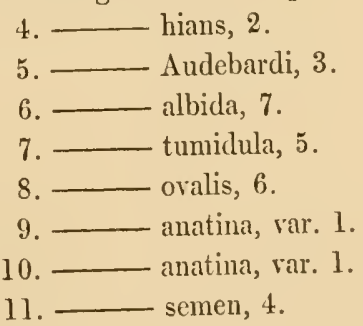

Printed by Reeve, Brothers, King William Street, Strand. 



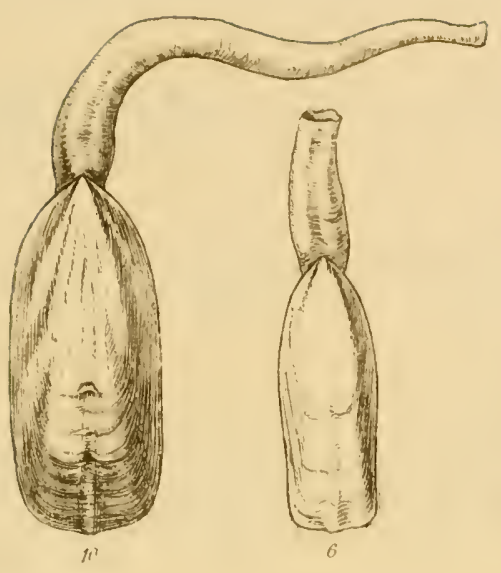

0
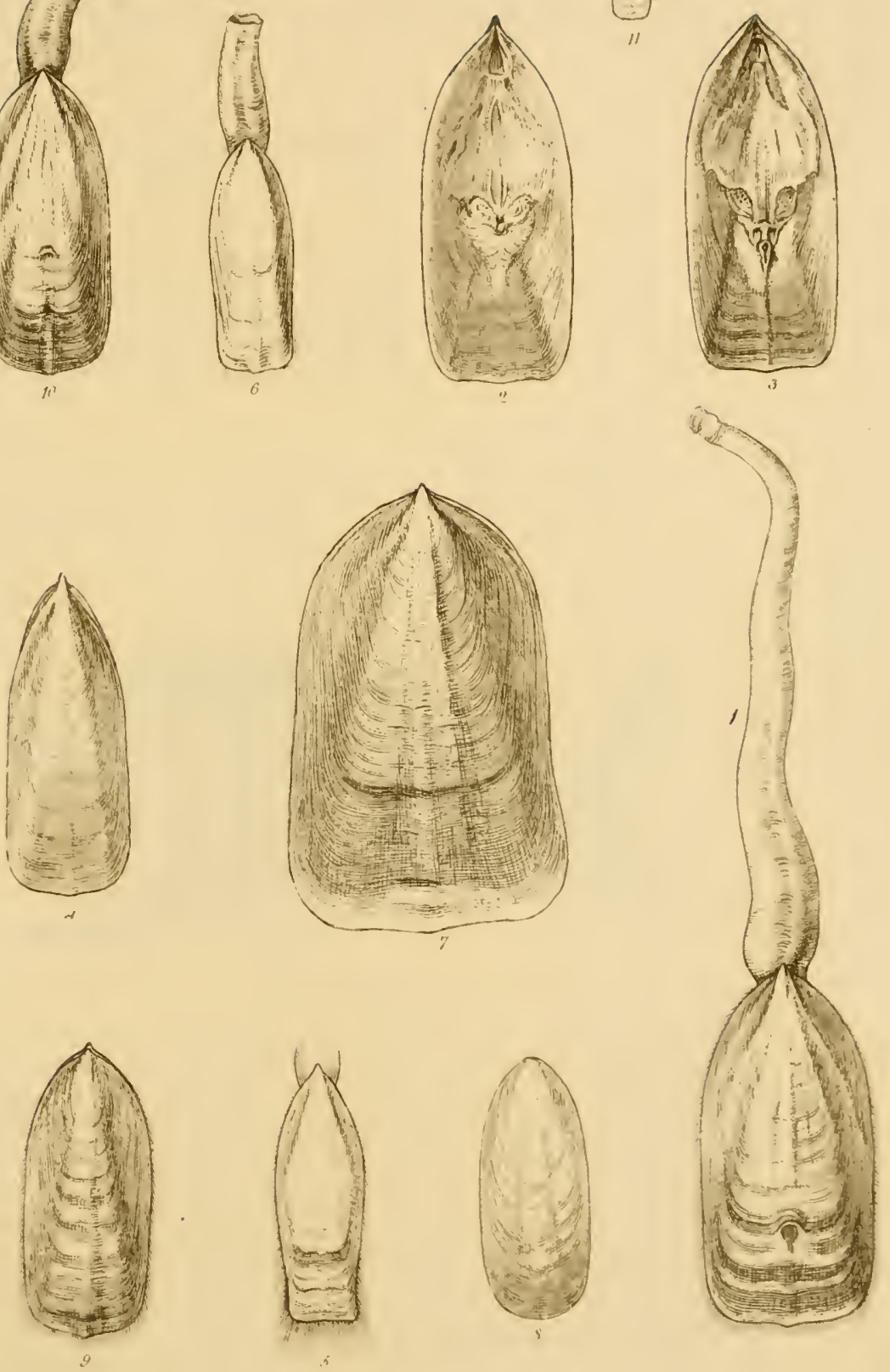

PREPARING FOR PUBLICATION,

In Numbers, profusely illustrated, price $2 s .6 d$. each, plain; 3s.6d. coloured, size royal 8vo.

\section{ELEMENTS OF CONCHOLOGY,}

COMPRISING

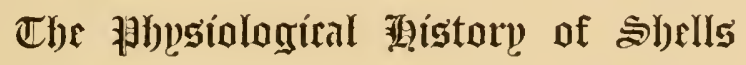

AND

THEIR MOLLUSCOUS INHABITANTS,

THEIR GEOGRAPHICAL DISTRIBUTION, HABITS, CHARACTERS, AFFINITIES

ARRANGEMENT, AND ENUMERATION OF SPECIES.

BY

\section{LOVELL REEVE, A.L.S. ETc.}

AUTHOR OF THE 'CONCHOLOGIA ICONICA'.

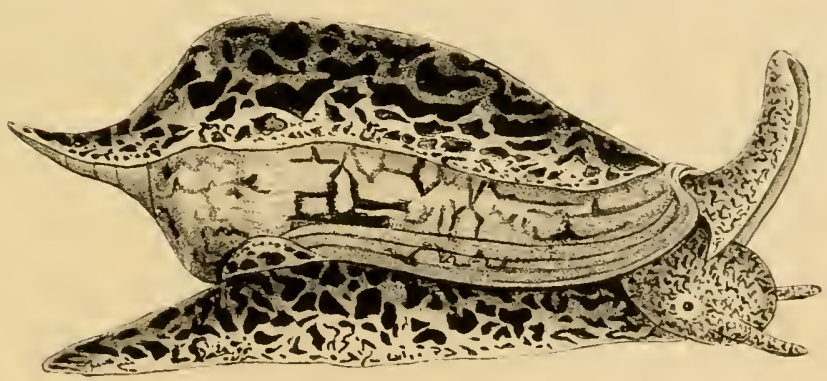

Voluta angulatu.

THE object of the present work is to invest the Science of Conchology with a high and interesting character, in an elementary form; to introduce in an explanatory and popular style, what has almost been confined (except in the admirable example begun by Mr. Gray in 'Turton's British Shells') to the regions of physical anatomy ; and to ennoble the spirit of collecting shells, by inducing a love of enquiry into the nature and habits of their molluscous inhabitants. Shells are too frequently collected in the present day as mere objects of fancy or ornament, fascinating the amateur by their varieties or form and colour, without exciting the least enquiry as to their nature or zoological character. The Conchologist should look upon his shells, in the 
absence of the living parts, as the medals of a creation whose history may to a great extent be ascertained by their structure and animal-impressions ; and to exhibit their connection it is only necessary to present him with a few of the typical kinds with the animal in situ. Many erroneous notions have prevailed in regard to this most interesting science, for want of properly estimating the very important relation between shells and their molluscous inhabitants. Collectors are still prejudiced in favour of the antiquated notions of Linnæus. They arrange their shells according to the varieties of jorm and external aspect, forgetting, that they are merely a collection of skeletons, the calcified portions of animals possessing an organization far superior to that of the Bee, and a thousand creatures whose structure and sagacity of habits have so often excited their admiration.

It is proposed in the "Elements of Conchology" to give an account, not of the anatomical detail of the Mollusca, but of their habits, affinities, and mode of producing shells, their structure, geographical distribution, and systematic arrangement, with the names of all the species known up to the time of publication; accompanied by a characteristic shell-figure of every genus, and one of a shell with its living animal in illustration of each particular group.

The drawings of the shells with animals will be mainly derived from those magnificent, but almost inaccessible, Zoologies of Surveying Expeditions published by the French Government, including that by M. Lesson in the 'Voyage de la Coquille', by M. M. Quoy and Gaimard in the 'Voyage de l'Astrolabe', by M. D'Orbigny in the 'Voyage dans l'Amerique Mèridionale' and by M. Deshayes in the 'Mollusques de l'Algérie'; and the author trusts by a popular generalization of the facts at present veiled in physiological obscurity, to give the elementary study of Conchology a more legitimate tone, and make it as easy as it is full of scientific interest.

To cxpect a work of this nature to become popular it must be well illustrated, and it must be cheap ; and the author has assuredly the means of accomplishing these objects with peculiar facility in the possession of a wellorganized printing establishment.

It is fully expected that the Work will not exceed about twelve numbers, and as a guarantee for its completion it may be added that Mr. G. B. Sowerby Jun. has been for some time occupied in engraving the figures upon copper-plate, of which between two and three hundred are already finished.

The first Number will be published in the course of January.

** Subscribers are earnestly solieited to favour the Publishers with their names as early as possible.

\section{LONDON :}

REEVE, BROTHERS, KING WILLIAM STREET, STRAND;

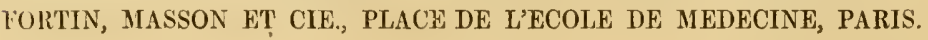









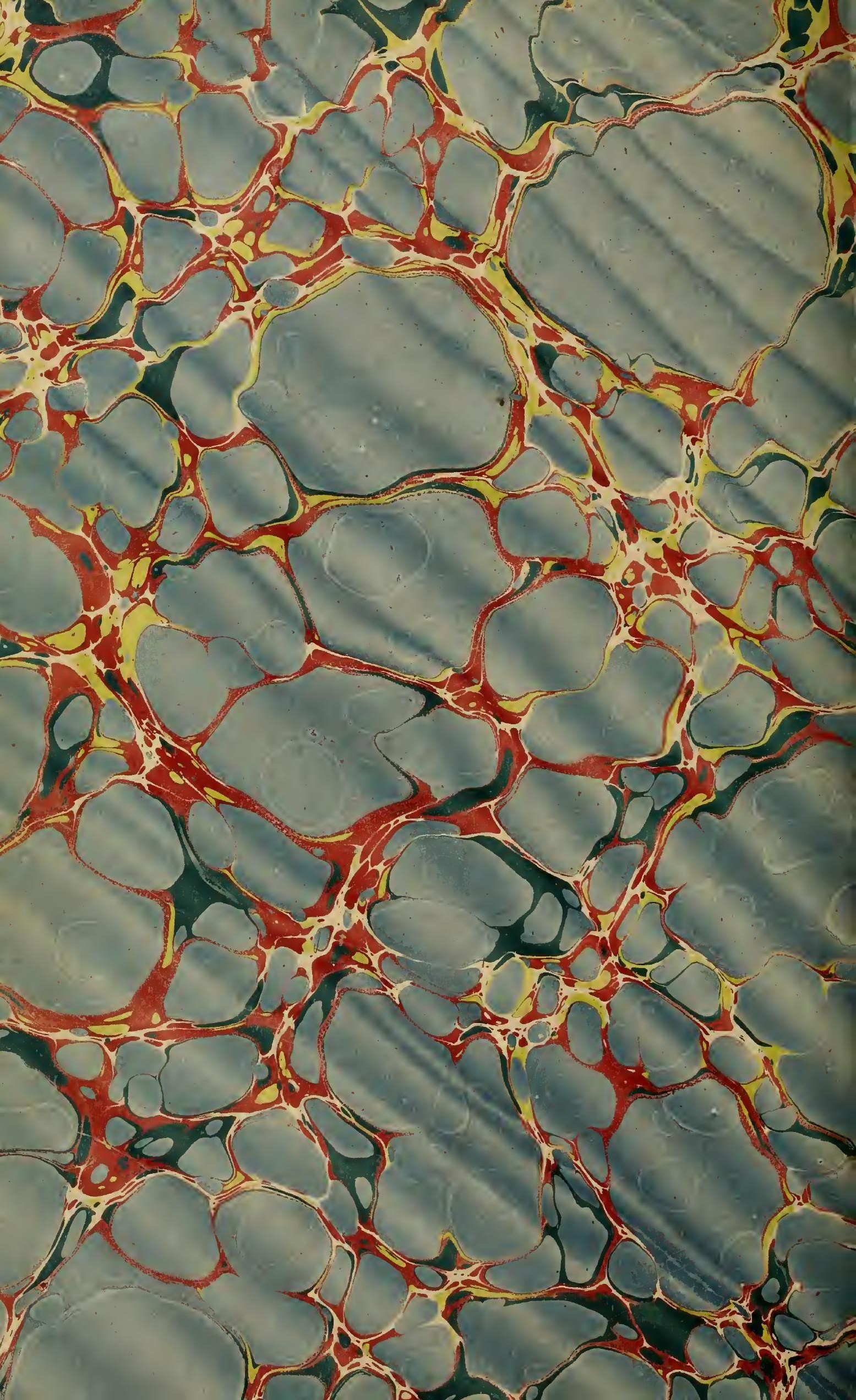




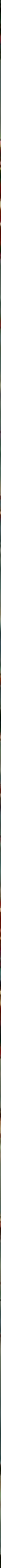


